https://doi.org/10.18778/1644-857X.20.01.05

ZBigniew ANUSIK

UNIWERSYTET ŁÓDZKi / UNIVERSiTy OF LODZ

iD https://orcid.org/0000-0002-5483-4970

\title{
Sienieńscy herbu Dębno \\ (lubelska gałąź rodu) w XVI i XVII wieku
}

Abstract

\section{Sienieńskis, Dębno coat of arms (Lublin line of the family) in $16^{\text {th }}$ and $17^{\text {th }}$ centuries}

\begin{abstract}
The well-known, senatorial Sienieński family, Dębno coat of arms has not yet 1 received a reliable genealogical study. The few attempts at presenting the genealogy of this family should be considered unsuccessful. They are full of all sorts errors and distortions. The article, written on the basis of extensive archival research, presents the genealogy of the least known Lublin Sienieński line. The author identified and described the lives of several dozen descendants of Wiktoryn Sienieński (died before 1556). He corrected and completed the biographical data of two representatives of this lineage who had biographies in Polski słownik biograficzny - the Lublin castellan Zbigniew (died 1633) and titular Maronite bishop Dominik (died 1743). He meticulously traced the marriages concluded by the members of the Sienieński family. He also presented their material status, as well as the most important facts from the lives of the most significant representatives of this family line. He also made some remarks of a more general nature. $\mathrm{He}$ drew attention to the fact that the peak of the splendor of the Sienienski family from Lublin voivodeship fell in the first half of the $17^{\text {th }}$ century. In the second half of this century, their importance and position suddenly collapsed. The distribution of landed property among nine men alive at that time led to their relative impoverishment. The Sienieńskis also gradually lost their possessions. At the end of $17^{\text {th }}$ century, they no longer owned any property in Lublin voivodeship.
\end{abstract}

Keywords: Sienieńskis, Dębno coat of arms, Polish nobility, Lublin voivodeship, Polish-Lithuanian Commonwealth in $16^{\text {th }}$ and $17^{\text {th }}$ centuries, genealogy 
STREsZCZEnie

Z nana, senatorska rodzina Sienieńskich herbu Dębno nie doczekała się dotąd rzetelnego opracowania genealogicznego. Nieliczne próby przedstawienia genealogii tego rodu należy uznać za nieudane, pełno w nich bowiem różnego rodzaju błędów i przekłamań. W artykule, napisanym na podstawie zakrojonych na szeroka skalę badań archiwalnych, przedstawiono genealogię i dzieje najmniej znanej, lubelskiej linii Sienieńskich. Autor zidentyfikował i opisał dzieje życia kilkudziesięciu potomków Wiktoryna Sienieńskiego (zm. p. 1556). Skorygował i uzupełnił dane biograficzne dwóch przedstawicieli tej linii, którzy doczekali się biogramów w Polskim słowniku biograficznym - kasztelana lubelskiego Zbigniewa (zm. 1633) i tytularnego biskupa maronickiego Dominika (zm. 1743). Drobiazgowo prześledził zawierane przez Sienieńskich związki małżeńskie. Przedstawił też ich sytuację majątkową, jak również najważniejsze fakty z życia najbardziej znaczących przedstawicieli tej linii rodu. Zawarł również kilka uwag bardziej ogólnej natury. Zwrócił uwagę na fakt, że apogeum świetności Sienieńskich z Lubelskiego przypadło na pierwsza połowę XVII w. W drugiej połowie tego stulecia nastapiło zaś gwałtowne załamanie ich znaczenia i pozycji. Podział dóbr między dziewięciu żyjących w tym czasie mężczyzn doprowadził bowiem do ich relatywnego zubożenia. Sienieńscy stopniowo tracili też swoje posiadłości. Pod koniec XVII w. nie byli już właścicielami żadnego majątku w Lubelskiem.

Słowa kluczowe: Sienieńscy herbu Dębno, szlachta polska, województwo lubelskie, Rzeczpospolita w XVI i XVII w., genealogia

$\mathrm{P}$

rzystępując do pisania tekstu poświęconego znanemu, senatorskiemu rodowi Sienieńskich h. Dębno, trzeba zacząc od stwierdzenia, że najwyraźniej nie mieli oni szczęścia do genealogów. Wszystkie podejmowane do tej pory próby opracowania genealogii tego rodu uznać należy za nieudane, przy czym uwaga ta dotyczy zarówno tablic genealogicznych, jak i niezbyt rozbudowanych tekstów w herbarzach. Przy bliższym zapoznaniu się $z$ nimi okazuje się bowiem, że sa one nie tylko dalece niekompletne, lecz także pełne różnego rodzaju błędów i nieścisłości ${ }^{1}$. Rzecz jasna najbardziej pożądanym przedsięwzięciem badawczym byłoby przygotowanie monografii uwzględniającej wszystkich przedstawicieli interesującego nas rodu. Ze względu na niedostępność ważnych

\footnotetext{
${ }^{1}$ Por. B. Paprocki, Herby rycerstwa polskiego, wyd. K.J. Turowski, Kraków 1858, s. 384-387; K. Niesiecki, Herbarz polski, wyd. J.N. Bobrowicz, t. VIII, Lipsk 1841, s. 354-360; B.H. Łuszczyński, Silva heraldica, t. VII, s. 259-264, rękopis w Bibliotece Narodowej w Warszawie, sygn. IV 5582; T. Żychliński, Złota ksiegga szlachty polskiej, t. III, Poznań 1881, s. 339-344; t. VIII, Poznań 1886, tabl. 3 po s. 496; W. Dworzaczek, Genealogia, t. II (Tablice), Warszawa 1959, tabl. 107.
} 
źródeł (przede wszystkim ksiąg grodzkich i ziemskich z województwa sandomierskiego) wydaje się to jednak zadaniem bardzo trudnym do wykonania. Po głębszym zastanowieniu uznałem natomiast, że dysponuję wystarczająca podstawą źródłową do przygotowania studium poświęconego genealogii i dziejom najmniej znanej, lubelskiej gałęzi rodu Sienieńskich.

Za protoplastę tej linii omawianej rodziny należy uznać kasztelana małogoskiego Wiktoryna $z$ Sienna i Gołogór h. Dębno (ok. 14631530). Był on synem podkomorzego sandomierskiego Andrzeja z Sienna i Rymanowa (zm. 1494) oraz Katarzyny z Gołogór, a wnukiem wojewody sandomierskiego Dobiesława $z$ Oleśnicy i Sienna (zm. 1440) ${ }^{2}$. Wydawać by się mogło, że najnowsze ustalenia nauki historycznej na temat życia i działalności kasztelana małogoskiego zostały zawarte w biogramie Wiktoryna Sienieńskiego opublikowanym w Polskim słowniku biograficznym ${ }^{3}$. Niestety, autor tego tekstu - Feliks Kiryk, piszac o rodzinie kasztelana, popełnił kilka istotnych błędów. Po pierwsze, podał nieprawdziwa datę ślubu (przed 1485 r.) Wiktoryna $z$ Sienna $z$ Elżbieta, córką kasztelana krakowskiego Jakuba $z$ Dębna h. Odrowąż (zm. 1490). W rzeczywistości małżeństwo to zostało bowiem zawarte w 1494 r. ${ }^{4}$ Po drugie, $z$ nieznanych powodów zignorował przekazana przez Bartosza Paprockiego informację, że kasztelan małogoski Wiktoryn Sienieński pozostawił po sobie dwóch synów: Zbigniewa, pana na Rymanowie, oraz Wiktoryna, dziedzica Chrośliny5. Kiryk nie wiedział również, że po śmierci pierwszej żony kasztelan małogoski ożenił się ponownie. Jego wybranką została Katarzyna z Chotczy Chotecka h. Nabram. Jako wdowa po Wiktorynie żyła ona jeszcze 29 czerwca 1547 r., gdy w sadzie ziemskim lubelskim został umorzony proces,

2 Por. F. Kiryk, Sienieński Andrzej z Sienna i Rymanowa, [w:] Polski słownik biograficzny [dalej: PSB], t. XXXVII, Warszawa-Kraków 1996-1997, s. 172; ide m, Oleśnicki Dobiesław (właściwie Dobek z Oleśnicy i Sienna), [w:] ibidem, t. XXIII, Wrocław 1978, s. 762-763; W. Dworzaczek, op. cit., t. II, tabl. 107.

${ }^{3}$ Por. F. Kiryk, Sienieński Wiktoryn z Sienna i Gołogór, [w:] PSB, t. XXXVII, Warszawa-Kraków 1996-1997, s. 192.

4 Ślub Wiktoryna i Elżbiety musiał się odbyć krótko przed 28 V 1494 r. Tego dnia bowiem Sienieński oprawił żonie 4500 florenów węgierskich wiana i przywianku na połowie swoich dóbr. Por. Archiwum Główne Akt Dawnych w Warszawie [dalej: AGAD], Metryka Koronna [dalej: MK] 15, f. 69.

${ }_{5}$ Por. B. Pa procki, op. cit., s. 387. Warto w tym miejscu odnotować, że Bartłomiej (Bartosz) Paprocki (ok. 1543-1614) miał bardzo dobre rozeznanie w stosunkach rodzinnych współczesnych sobie wielmożów. Podane przez niego informacje znajdują bowiem najczęściej potwierdzenie również w innych źródłach. 
jaki toczyła ze swoim krewnym, Pawłem Choteckim, dziedzicem w Chotczy ${ }^{6}$.

Kiryk stwierdził także, że zmarły w 1530 r. Wiktoryn Sienieński pozostawił po sobie jedynie syna Zbigniewa oraz córki: Agnieszkę, zamężna najpierw $z$ Piotrem Szafrańcem, a potem ze Stanisławem Niszczyckim, i Katarzynę, wydana za Andrzeja Tęczyńskiego, wojewodę krakowskiego ${ }^{7}$. Informacja ta wymaga uściślenia o tyle, że Sienieński miał również, oprócz wspomnianego Wiktoryna, także syna Dymitra, którzy też przeżył ojca. Wszyscy trzej synowie zmarłego 31 marca 1530 r. kasztelana małogoskiego, czyli Zbigniew, Wiktoryn i Dymitr wystapili bowiem w dokumencie wystawionym 3 lipca 1531 r. w Urzędowie, a odnoszącym się do sporu między Sienieńskimi a Stanisławem i Mikołajem z Rachowa, którzy mieli zostać poszkodowani przy rozgraniczeniu należących do kasztelaniców małogoskich wsi Chrośliny, Boisk i Woli Boiskiej z dobrami kapituły krakowskiej ${ }^{8}$. Jeśli chodzi o córki Wiktoryna Sienieńskiego, to starsza była Katarzyna, która już w 1517 r. została wydana za Andrzeja Tęczyńskiego, który zmarł 2 stycznia 1536 r. jako kasztelan krakowski. Sienieńska niewiele przeżyła męża. Zmarła bowiem bezpotomnie przed 29 kwietnia 1538 r. ${ }^{9}$ Młodsza $z$ kasztelanek małogoskich - Agnieszka, dopiero w 1530 r. poślubiła kasztelanica wiślickiego Piotra Szafrańca $z$ Pieskowej Skały h. Starykoń, z którym miała syna Stanisława (ok. 1531-1598). Po rychłej

${ }^{6}$ Por. B.H. Łuszczyński, op. cit., t. VII, s. 261 (tu informacja, że Katarzyna $z$ Chotczy była żoną kasztelana małogoskiego Wiktoryna Sienieńskiego); Archiwum Państwowe w Lublinie [dalej: APL], Lubelskie ziemskie, Wieczyste [dalej: LZW], nr 80, k. 559-560 (tu Katarzyna występuje jako wdowa po wielmożnym Wiktorynie Sienieńskim).

7 Por. F. Kiryk, Sienieński Wiktoryn..., s. 192. Podobnie w tablicach opracowanych przez W. Dworzaczka, gdzie również brakuje wzmianki o Wiktorynie juniorze. Nie odnotowano tu również żon i potomstwa Zbigniewa. Por. idem, op. cit., t. II, tabl. 107.

${ }^{8}$ Por. Wyciag $z$ akt ziemskich urzędowskich $z$ dnia 3 VII 1531 r. odnoszacy się do sporu między Stanisławem i Mikołajem z Rachowa, a Zbigniewem, Wiktorynem i Dymitrem, synami nieżyjącego Wiktoryna Sienieńskiego, kasztelana małogoskiego, o straty w gruntach poniesione przez Rachowskich przy rozgraniczeniu wsi Sienieńskich Chrośliny, Boisk i Woli Boiskiej z dobrami kapituły krakowskiej, Biblioteka Książąt Czartoryskich - Muzeum Narodowe w Krakowie, sygn. 1286 Perg.

${ }^{9}$ Por. J. Kurtyka, Latyfundium tęczyńskie. Dobra i właściciele (XIV-XVII wiek), Kraków 1999, s. 170-175 (na s. 174 wzmianka, że Katarzyna była córka kasztelana małogoskiego Wiktoryna, a siostra Zbigniewa, Wiktoryna i Agnieszki, żony Piotra Szafrańca). 
śmierci pierwszego męża, najpewniej w 1532 r. wyszła ponownie za Stanisława Niszczyckiego h. Prawdzic (ok. 1500-1556), z czasem wojewodę płockiego, z którym miała trzech synów: Jana, Piotra i Krzysztofa ${ }^{10}$. Dodajmy również, że nieprawdziwe jest stwierdzenie autora biogramu kasztelana małogoskiego, jakoby posiadał on dobra w ziemi sandomierskiej z ośrodkiem w Chruszczynie ${ }^{11}$. W rzeczywistości bowiem, oprócz klucza rymanowskiego w ziemi sanockiej, Wiktoryn Sienieński był właścicielem kilku wiosek w powiecie urzędowskim, a ośrodkiem jego lubelskich posiadłości była wspomniana już kilkakrotnie Chroślina (dziś Chruślina).

Najmłodszy z kasztelaniców małogoskich - Dymitr, zmarł młodo i bezpotomnie. Dlatego też B. Paprocki mógł napisać później (nie do końca zgodnie ze stanem faktycznym), że Wiktoryn Sienieński (zm. 1530) miał tylko dwóch synów. Starszy z nich - Zbigniew (zm. 1567/1568), w przyszłości kasztelan sanocki, objął w posiadanie Rymanów z przyległościami i był protoplasta rymanowskiej

10 Por. J. Sperka, Szafraniec Piotr młodszy z Pieskowej Skały, [w:] PSB, t. XLVI, Warszawa-Kraków 2009-2010, s. 467; oraz I. Gi e y s z to row a, Niszczycki Stanisław, [w:] ibidem, t. XXIII, Wrocław 1978, s. 139. Stosunkowo duża różnica wieku między córkami Wiktoryna Sienieńskiego nasuwa pytanie o to, czy wszystkie jego dzieci pochodziły $z$ małżeństwa $z$ Elżbieta $z$ Dębna, która po raz ostatni została odnotowana w źródłach w roku 1504, gdy wyraziła zgodę na zastawienie przez męża Piotrowi Herburtowi z Fulszyna wsi Klimkówka i Ladzin w kluczu rymanowskim. Por. A. Fastnacht, Słownik historyczno-geograficzny ziemi sanockiej $w$ średniowieczu, do druku przygotowali A. Fastnacht-Stupnicka, A. Gasiorowski, cz. 2, Brzozów-Wzdów-Rzeszów 1998, s. 62, 106; F. Kiryk, Sienieński Wiktoryn..., s. 192 (tu jednak nieprawdziwa informacja o zastawieniu Herburtowi całych dóbr rymanowskich). Córką Elżbiety była na pewno urodzona około 1499 r. Katarzyna z Sienna Tęczyńska. Przed 1504 r. urodził się też najpewniej Zbigniew, który w 1530 r. ożenił się z Anną Tęczyńska, córką Jana (zm. 1552), w przyszłości wojewody sandomierskiego. Por. J. Ku rty ka, op. cit., s. 199. Rzecz jasna Elżbieta z Dębna, która urodziła się najwcześniej w roku 1476, mogła być matką Wiktoryna, Dymitra oraz urodzonej około 1512 r. Agnieszki. Ponieważ jednak nie znamy ani daty śmierci Elżbiety, ani też dat narodzin wspomnianej trójki rodzeństwa, kwestii tego, kto był ich matką, nie podejmuję się rozstrzygnąć.

11 Por. F. Kiryk, Sienieński Wiktoryn..., s. 192. Warto też zwrócić uwage na to, że informacja o leżącej jakoby w powiecie wiślickim Chruszczynie (Chroślinie) pojawia się także w opracowanym przez tego samego autora biogramie ojca kasztelana małogoskiego. Por. idem, Sienieński Andrzej..., s. 172. W kwestii poprawek i uzupełnień dotyczących biografii kasztelana małogoskiego Wiktoryna Sienieńskiego por. też Z. Anusik, Krag rodzinny Katarzyna z Sienna Myszkowskiej (zm. 1619), podczaszyny lubelskiej. Studium genealogiczno-obyczajowe, „Przegląd Nauk Historycznych” 2020, R. XIX, nr 2, s. 246-248. https://doi.org/ 10.18778/1644-857X.19.02.10 
gałęzi rodu Sienieńskich ${ }^{12}$. Młodszy - Wiktoryn przejął dobra ojcowskie w powiecie urzędowskim. On $z$ kolei był przodkiem wszystkich przedstawicieli lubelskiej (nieznanej w zasadzie genealogom) linii rodu Sienieńskich. Wiemy o nim, że oprócz dóbr w województwie lubelskim posiadał również dziedziczną włość stołpińską w ziemi lwowskiej, w skład której wchodziły wsie: Stołpin, Bołożynów, Turza, Przewłoczna, Kobyle i Wola. Dnia 20 czerwca 1552 r. Wiktoryn Sienieński wniósł bowiem do ksiąg ziemskich lubelskich akt donacji (w istocie sprzedaży) tego klucza na rzecz Andrzeja Dembowskiego, chorążego łęczyckiego i starosty hrubieszowskiego. Zgodę na przeprowadzenie tej transakcji wyraziła żona Sienieńskiego Anna. Nie znamy niestety jej nazwiska. Wiadomo jedynie, że stawiła się ona w Lublinie w towarzystwie krewnych ze strony ojca (fratres ex linea paterna), Walentyna Lubczyńskiego i Stanisława Wierzbickiego ${ }^{13}$. Nie znamy również daty śmierci młodszego $z$ kasztelaniców małogoskich. Nie żył on już jednak na pewno 21 czerwca 1559 r., gdy Paweł Czerny z Witowic h. Nowina oprawił posag swojej żony Zofii, córki nieżyjącego Wiktoryna Sienieńskiego $z$ Chrośliny. Ta $z$ kolei, zaspokojona kwota 3500 florenów, zeznała ustapienie $z$ dóbr na rzecz swoich braci: Stanisława, Marcina, Jakuba, Andrzeja i Jana ${ }^{14}$.

Jak więc widzimy, kasztelanic małogoski Wiktoryn Sienieński pozostawił po sobie pięciu synów i jedną córkę. Ta ostatnia, wspomniana Zofia, już jako wdowa po Pawle Czernym, żyła jeszcze w 1602 r., gdy ze swoimi czterema synami, Janem, Jerzym, Przecławem i Pawłem, została odnotowana w księgach sądu ziemskiego lubelskiego ${ }^{15}$. Zarówno Zofia, jak i jej czterej starsi bracia byli dziećmi Wiktoryna i jego pierwszej żony Anny. Matka najmłodszego $z$ rodzeństwa - Jana była jednak druga żona kasztelanica małogoskiego, Jadwiga Leska h. Janina, która w pierwszej połowie 1572 r., występując przed aktami ziemskimi lubelskimi jako wdowa po Wiktorynie, dokonała zapisu na rzecz swojego syna, Jana

${ }^{12}$ Por. F. Kiryk, Sienieński Zbigniew z Sienna i Rymanowa, [w:] PSB, t. XXXVII, s. 192-193; J. Kurtyka, op. cit., s. 199.

${ }^{13}$ Por. APL, LZW, nr 81, k. 216-218. Warto tu dodać, że Andrzej Dembowski został w przyszłości wojewodą bełskim, a jego jedyna córka Zofia wniosła dobra stołpińskie swojemu mężowi, Andrzejowi Tęczyńskiemu, który zmarł w 1588 r. jako wojewoda krakowski.

14 Por. APL, LZW, nr 82, k. 225v-226v.

15 Por. APL, Lubelskie ziemskie, Sądowe [dalej: LZS], nr 51, k. 529-530. 
Sienieńskiego ${ }^{16}$. Dwaj synowie Wiktoryna i Anny, Marcin i Andrzej zmarli bezpotomnie przed 3 maja 1571 r. Tego dnia Stanisław, Jakub i Jan Sienieńscy dokonali bowiem w Urzędowie podziału dóbr po ojcu ${ }^{17}$. Nie znamy co prawda treści tego dokumentu, ale na podstawie innych źródeł $z$ cała pewnością możemy stwierdzić, że najmłodszy $z$ braci - Jan otrzymał wieś Chroślinę. Najstarszemu Stanisławowi przypadły Boiska, Wola Grabowa (Grabówka), Wola Sosnowa, Wrzawy, Strachocin, Goczałkowice i Białkowice. Średni $z$ braci - Jakub wziął natomiast ze schedy po ojcu Mazanów, Wałowice, Wolę Lubaszowa, Prawno, Glinnik, Ocierchów, Skowierzyn oraz Radomyśl. Pewne wyobrażenie o wartości ekonomicznej poszczególnych działów dają informacje zawarte w rejestrze poborowym województwa lubelskiego z $1626 \mathrm{r}$. W Choślinie było wówczas 25 łanów osiadłych, w Boiskach - 10,5 łanu, w Woli Sosnowej - 3,25 łanu, w Grabówce - 3,5 łanu, we Wrzawach i Strachocinie - 4,5 łanu (łącznie w dziale Stanisława - 21,75 łanu), w Mazanowie - 2 łany, w Wałowicach - 2 łany, w Woli Lubaszowej 1,5 łanu, w Prawnie, które było wówczas miasteczkiem, 1 łan, w Glinniku - 2 łany, w Ocierchowie - 1,5 łanu, w Skowierzynie 3 łany i wreszcie, w będącym także miasteczkiem Radomyślu - 1,5 łanu (łacznie w dziale Jakuba - 14,5 łanu) ${ }^{18}$.

Stanisław Sienieński, najstarszy syn kasztelanica małogoskiego Wiktoryna, nie zaznaczył niczym swojej obecności na scenie politycznej. Zawarł jednak bardzo korzystne i prestiżowe małżeństwo. Poślubił bowiem nieznaną $z$ imienia córkę wojewody bełskiego Mikołaja Niszczyckiego h. Prawdzic (zm. 1542). Wobec

16 Por. APL, LZW, nr 84, k. 26-26v.

17 Wzmianka o tym akcie, bez podania jednak jakichkolwiek szczegółów, por. APL, Lubelskie grodzkie, Relacje [dalej: LGR], nr 55, k. 539-539v. Warto w tym miejscu dodać, że pierwsza żona Wiktoryna Sienieńskiego - Anna musiała umrzeć wkrótce po potwierdzeniu transakcji sprzedaży dóbr stołpińskich, skoro syn jego drugiej żony już w 1571 r. mógł podejmować wiążące decyzje prawne. Nie dziwi również to, że wobec wczesnej śmierci Marcina i Andrzeja Sienieńskich B. Paprocki odnotował w swoim herbarzu, że Wiktoryn Sienieński pozostawił po sobie jedynie trzech synów: Stanisława, Jakuba i Jana. Por. id e m, op. cit., s. 387.

18 Por. Rejestr poborowy województwa lubelskiego (powiat lubelski i urzędowski z r. 1626, ziemia łukowska z r. 1620) [dalej: Rejestr lubelski 1626], oprac. J. Kolasa i K. Schuster, red. S. Inglot, Wrocław 1957, s. 92-93, 99-100, $103,108$. Warto zwrócić uwagę na to, że wsie Goczałkowice i Białkowice, wchodzące w skład majętności wrzawskiej, nie zostały w tym rejestrze odnotowane. W kwestii ustaleń dotyczących kasztelanica małogoskiego Wiktoryna Sienieńskiego oraz jego potomstwa por. też Z. Anusik, op. cit., s. 248-250. 
bezpotomnej śmierci jedynego syna wojewody - Stanisława dobra Mikołaja zostały podzielone między jego cztery córki (Grabowiecka, Sempelborska, Sienieńską i Kossobudzka), które „wyniosły wielką część majętności $z$ domu Niszczyckich"19. Dzięki małżeństwu $z$ wojewodzianka bełską Stanisław Sienieński przejął ze schedy po jej ojcu miasteczko Uhnów oraz wsie Tarnoszyn i Ulhówek w województwie i powiecie bełskim. Jego własność w Tarnoszynie i Ulhówku odnotowano $\mathrm{w}$ rejestrze poborowym województwa bełskiego z 1578 r. Od niego też w roku następnym próbował przejąć Uhnów w zastawne posiadanie kanclerz wielki koronny Jan Zamoyski ${ }^{20}$. Po śmierci pierwszej żony Stanisław Sienieński ożenił się po raz drugi z Agnieszką Marcinowską h. Topór, której zabezpieczył 2000 florenów posagu na Woli Sosnowejej ${ }^{21}$ Żył jeszcze w 1595 r. Nie żył już na pewno 12 marca $1601 \mathrm{r}$. Zapewne krótko przed śmiercią sprzedał Boiska, Grabówkę i Wolę Sosnową swojemu zięciowi, podczaszemu lubelskiemu Stanisławowi Myszkowskiemu ${ }^{22}$. Z małżeństwa $z$ Niszczycka miał synów Mikołaja i Jakuba oraz córki Annę i Katarzynę ${ }^{23}$. Ze związku z Agnieszką Marcinowską Stanisław Sienieński pozostawił tylko jedną córkę - Zofię ${ }^{24}$.

Anna Sienieńska, jedna $z$ dwóch córek Stanisława i Niszczyckiej, poślubiła Krzysztofa Żukowskiego, właściciela wsi Sobianowice. Obciążyła ona bliżej nieokreślonym długiem miasto Uhnów w województwie bełskim, które było wspólnym dziedzictwem (po matce) dzieci Stanisława $z$ jego pierwszego małżeństwa. O przeniesienie

${ }_{19}$ Por. B. Paprocki, op. cit., s. 621.

${ }^{20}$ Por. Źródła dziejowe, t. XVIII, cz. 1 (Polska XVI wieku pod względem geograficzno-statystycznym), t. VII (Ziemie ruskie. Ruś Czerwona), cz. 1, wyd. A. Jabłonowski, Warszawa 1902, s. 206; Jan Tomasz Drohojowski do Jana Zamoyskiego, Przemyśl 29 III 1579; Maciej Topornicki do J. Zamoyskiego, Zamech 2 IV 1579, Archiwum Jana Zamoyskiego, kanclerza i hetmana wielkiego koronnego, t. I (15531579), wyd. W. Sobieski, Warszawa 1904, s. 305-306, 308-309. Co ciekawe, korzystający $z$ tych samych listów A. Tarnawski zupełnie bezpodstawnie uznał, że Jan Zamoyski w 1579 r. wziął w posesję Uhnów od kasztelana halickiego Jana Sienieńskiego. Por. i d e m, Działalność gospodarcza Jana Zamoyskiego kanclerza $i$ hetmana w. kor. (1572-1605), Lwów 1935, s. 43. Por. też Z. Anusik, op. cit., s. 251-252.

${ }^{21}$ Por. APL, LGR, nr 44, k. 547v-550v; Z. Anusik, op. cit., s. 252.

${ }^{22}$ Dokument, w którym Stanisław Sienieński został określony jako zmarły, por. AGAD, MK 147, f. 53. Więcej o okolicznościach nabycia przez Stanisława Myszkowskiego dóbr boiskich por. Z. Anusik, op. cit., s. 252, 262.

${ }^{23}$ Por. APL, Lubelskie ziemskie, Wieczyste i zobowiązania [dalej: LZWZ], nr 106, k. 428v-430v; Z. Anusik, op. cit., s. 252.

${ }^{24}$ Por. APL, LGR, nr 44, k. 547v-550v, 653v-655; Z. Anusik, op. cit., s. 252. 
tego ciężaru na Sobianowice starał się w 1607 r. ówczesny dziedzic tego miasteczka, Mikołaj Sienieński, z którym Anna zawarła jakąś umowę majątkowa pod stosunkowo wysokim zakładem 17 tys. florenów. Stosunki Anny $z$ tym bratem układały się bardzo dobrze. Mikołaj Sienieński wspierał bowiem małżonków Żukowskich w ich procesie $z$ Krzysztofem Grekiem o część wsi Rybczyce, a po śmierci Anny z Sienna, która zmarła przed 2 czerwca 1607 r., kontynuował ten proces w interesie jej dzieci: Stanisława, Jakuba i Anny Żukowskich ${ }^{25}$.

O wiele więcej możemy powiedzieć o drugiej córce Stanisława i Niszczyckiej - Katarzynie. Przed 1590 r. została ona wydana za dużo starszego od niej Jana Biejkowskiego h. Jastrzębiec, stolnika przemyskiego i starostę gabińskiego, wdowca po Zofii Rzeszowskiej h. Doliwa. Był on osobistością znaną i popularną wśród szlachty. Brał czynny udział w życiu politycznym. Sześciokrotnie posłował na sejm. Z małżeństwa $z$ Katarzyna Sienieńską (podobnie jak $z$ pierwszą żona) nie doczekał się jednak potomstwa. Zmarł bowiem bezpotomnie przed końcem 1590 r. Młoda wdowa dość szybko znalazła pocieszenie $\mathrm{w}$ ramionach drugiego małżonka - Mikołaja Ostrowskiego h. Leliwa, wdowca po Zofii Strońskiej h. Doliwa. Był on związany ze starosta przemyskim i referendarzem koronnym Janem Tomaszem Drohojowskim. $Z$ jego nominacji piastował urząd podstarościego przemyskiego. W 1589 r. Mikołaj Ostrowski został mianowany przez Zygmunta III podsędkiem przemyskim. Drugi mąż Katarzyny był człowiekiem zamożnym. W świetle danych zawartych $\mathrm{w}$ rejestrze poborowym ziemi przemyskiej z roku 1589 Ostrowski był właścicielem wsi Lipniki, Ostrów, Rokszyce oraz wsi zagrodniczej Prakowce (dziś Prałkowce). Podsędek przemyski zmarł jednak już pod koniec 1595 lub też na początku 1596 r. Wiemy na pewno, że jego pogrzeb odbył się przed 3 kwietnia 1596 r. $Z$ pierwszego małżeństwa Mikołaj Ostrowski miał syna Jana Mateusza. Z Katarzyna z Sienna doczekał się córki Zuzanny ${ }^{26}$.

${ }^{25}$ Por. APL, LGR, nr 37, k. 386v-387, 715-715v, 783; Z. Anu sik, op. cit., s. 252.

${ }^{26}$ Por. Ś. Orzelski, Bezkrólewia ksiag ośmioro, czyli dzieje Polski od zgonu Zygmunta Augusta r. 1572 aż do r. 1576, oprac. W. Spasowicz, Petersburg 1858, s. 206, 213, 221, 223-224, 243-244, 253, 262; E. Dub as-Urw an ow ic z, Koronne zjazdy szlacheckie $w$ dwóch pierwszych bezkrólewiach po śmierci Zygmunta Augusta, Białystok 1998, s. 331; W. Sokołowski, Politycy schyłku złotego wieku. Małopolscy przywódcy szlachty i parlamentarzyści w latach 1574-1605, Warszawa 1997, s. 176; Posłowie ziemscy koronni 1493-1600 [dalej: Posłowie ziemscy], oprac. W. Uruszczak, I. Kaniewska, M. Ferenc, J. Byliński, red. I. Kaniewska, 
Dnia 5 lipca 1596 r. opiekunowie dzieci i dóbr zmarłego podsędka przemyskiego Mikołaja Ostrowskiego roborowali w grodzie lubelskim akt ugody zawartej 3 kwietnia tego roku w Ostrowie $z$ wdowa po nim, Katarzyna $z$ Sienna ${ }^{27}$. $Z$ przywołanego tutaj dokumentu wynika, że w chwili śmierci drugi mąż Katarzyny był właścicielem sześciu wsi w ziemi przemyskiej oraz tenutariuszem jednej wsi królewskiej w ziemi sanockiej. Ostrów (4,75 łanu osiadłego), Rokszyce (3 łany), Prakowce (wieś zagrodnicza) oraz Siemieniece leżały nieopodal Przemyśla, a Lipniki (6 łanów) i Dydatycze (4,5 łanu) w pewnym oddaleniu, na południowy wschód od Mościsk. W skład będącej królewszczyzną wsi Wrocanka, położonej niedaleko Krosna, wchodziło natomiast wójtostwo (1 łan) oraz 4 łany kmiece ${ }^{28}$. Dokonany w początkach kwietnia 1596 r. podział spadku po Mikołaju Ostrowskim $z$ pewnością mógł zadowolić wdowę po nim. Oprócz Lipnik i połowy Dydatycz, na których miała zagwarantowane dożywocie, wzięła ona bowiem również w dożywotnie władanie Rokszyce, Prakowce i Siemienice. Zatrzymała w swoich rękach królewska Wrocankę (miała prawo do tej wsi na mocy ius communicativum

Warszawa 2013, s. 213, 223, 238-239, 264, 277, 321, 329; B.H. Łuszczyńs ki, op. cit., t. VI, s. 169 (tu informacja o pierwszej żonie Mikołaja Ostrowskiego, Zofii Strońskiej oraz o jego synu Janie Mateuszu. Autor nie wiedział jednak o tym, że druga żona Mikołaja była Katarzyna Sienieńska. Podał też błędna datę śmierci podsędka przemyskiego - 1603 r.); Źródła dziejowe, t. XVIII, cz. 1, t. VII, cz. 1, s. 19; Akta grodzkie i ziemskie z czasów Rzeczypospolitej Polskiej z Archiwum tak zwanego bernardyńskiego we Lwowie, t. XX (Lauda sejmikowe), t. I (Lauda wiszeńskie 1572-1648 r.), oprac. A. Prochaska, Lwów 1909, s. 69-70, 85-87. Por. też APL, LGR, nr 49, k. 754v-756 (tu Zuzanna Ostrowska jako córka Mikołaja i Katarzyny z Sienna); Z. Anusik, op. cit., s. 253-254.

27 Por. APL, LGR, nr 30, s. 1830-1844.

28 Por. Polska południowo-wschodnia w epoce nowożytnej. Źródła dziejowe, t. I, cz. 1 (Rejestr poborowy ziemi przemyskiej z 1628 roku), wyd. Z. Budzyński, K. Przyboś, Rzeszów 1997, s. 94 (Lipniki), 114 (Ostrów), 115 (Prałkowce i Rokszyce); Polska południowo-wschodnia w epoce nowożytnej. Źródła dziejowe, t. I, cz. 2 (Rejestr poborowy ziemi przemyskiej z 1651 roku), wyd. Z. Budzyński, K. Przyboś, Rzeszów 1997, s. 31 (Dydatycze); Polska południowo-wschodnia $w$ epoce nowożytnej. Źródła dziejowe, t. II, cz. 1 (Rejestr poborowy ziemi sanockiej z 1640 roku), wyd. Z. Budzyński, K. Przyboś, Rzeszów 1998, s. 9, 99 (Wrocanka). Warto w tym miejscu odnotować, że wydawcy tych rejestrów błędnie zidentyfikowali właścicieli wsi Lipniki, Ostrów, Prakowce, Rokszyce i Dydatycze. W 1628 r. wszystkie one należały bowiem do pasierba Katarzyny Sienieńskiej, Jana Mateusza Ostrowskiego, a w roku 1651 do jego syna Krzysztofa. W żadnym z przywołanych tu źródeł nie występuje natomiast wieś Siemienice, będąca zapewne przysiółkiem Prakowiec lub Rokszyc. Por. też Z. Anu sik, op. cit., s. 255-259. 
uzyskanego dla niej przez Jana Biejkowskiego). Dysponowała również dokonanym przez pierwszego męża zapisem 4000 florenów na Pełnatyczach. Jeśli zaś dodamy do tego gotówkę, złote precjoza, srebro i ruchomości odziedziczone po obu mężach, to musimy stwierdzić, że Katarzyna $z$ Sienna była po powtórnym owdowieniu osobą bardzo majętna ${ }^{29}$.

Najpóźniej w 1597 r. Katarzyna Sienieńska wyszła za mąż po raz trzeci. Tym razem oddała swoją rękę podczaszemu lubelskiemu Stanisławowi Myszkowskiemu h. Jastrzębiec. Był on jednym z czterech synów kasztelana lubelskiego Andrzeja (zm. 1566) i Zofii $z$ Sienickich h. Bończa (zm. 1569). Otrzymał bardzo solidne wykształcenie. Studiował w Bazylei, Zurichu i Heidelbergu. Bez wątpienia w młodości był wyznawca kalwinizmu. Później jednak dokonał konwersji na katolicyzm. W drugiej połowie 1586 r. otrzymał urząd podczaszego lubelskiego, który piastował do śmierci. Nie przejawiał większej aktywności na scenie politycznej. W roku 1605 został jednak wybrany posłem na rozdwojonym sejmiku lubelskim przez nastawiona życzliwie wobec Zygmunta III szlachtę łukowską i urzędowską. W wyniku podziału dóbr po rodzicach obją z młodszym bratem Krzysztofem dobra bychawskie w powiecie lubelskim. Dnia 24 kwietnia 1587 r. podzielono ten klucz w ten sposób, że Stanisław otrzymał miasto Bychawę $z$ zamkiem i Podgrodziem oraz wsie Zadybie i Zdrapy, a Krzysztof - wsie Wolicę (Wolę Bychawska) i Olszowiec. Dotrzymanie warunków tej umowy zabezpieczono wysokim zakładem 5000 florenów. Wypada sądzić, że podział był sprawiedliwy. W rejestrze poborowym województwa lubelskiego z 1626 r. odnotowano bowiem we wsi Wola alias Zadybie 2 łany osiadłe i 1,5 łanu pustego, we wsi Zdrapach - 1 łan osiadły i 0,5 łanu pustego, podczas gdy w Olszowcu było wówczas 6 łanów osiadłych i 2,5 łanu pustego, a w Woli Bychawskiej - 6,5 łanów osiadłych i 7,5 łanów pustych. Najpewniej niedługo potem Stanisław Myszkowski ożenił się z Zofią $z$ Trzcieńca Borkówną h. Wąż. Jak można przypuszczać, pierwsza żona podczaszego lubelskiego była córka Jana Borka $z$ Pawłowic i Jadwigi Broniowskiej h. Ostoja. Z małżeństwa tego pochodził starszy syn Stanisława - Jan Myszkowski ${ }^{30}$.

${ }^{29}$ Por. APL, LGR, nr 30, s. 1841-1844; Z. Anusik, op. cit., s. 259-260.

30 Por. H. Kowalska, Myszkowski Andrzej, [w:] PSB, t. XXII, Wrocław 1977, s. 368-369 (tu jednak błędna data śmierci Stanisława - 1603 r.); W. D w o r z ac ze k, op. cit., t. II, tabl. 130 (tu zaś brak wzmianki o pierwszym małżeństwie Stanisława Myszkowskiego); Urzędnicy województwa lubelskiego XVI-XVIII wieku. Spisy 
Pod koniec lat dziewięćdziesiątych XVI w. Stanisław Myszkowski sprzedał miasto Bychawę $z$ zamkiem, przedmieściem oraz wsiami Zadybie i Zdrapy podczaszemu chełmskiemu Pawłowi Wierzbickiemu h. Nieczuja. W każdym razie ten ostatni już 1 maja 1600 r. w aktach sądu ziemskiego lubelskiego został nazwany dziedzicem na Bychawie. Wkrótce po sprzedaży Bychawy Stanisław Myszkowski kupił od własnego teścia, Stanisława Sienieńskiego wsie Boiska, Wolę Grabowa (Grabówkę) i Wolę Sosnową w powiecie urzędowskim. Na dobra te przeniósł z włości bychawskiej oprawę drugiej żony. Jako pan na Boiskach podczaszy lubelski był teraz sasiadem bliskich krewnych Katarzyny z Sienna. To z nimi też miał przez lata toczyć różnego rodzaju spory. Najpierw jednak przeprowadził kilka transakcji $z$ własnymi szwagrami, czyli Mikołajem i Jakubem Sienieńskimi. Dnia 12 marca 1601 r. Katarzyna z Sienna uzyskała konsens królewski na cesję leżącej w ziemi sanockiej wsi Wrocanka $z$ wójtostwem na rzecz brata Jakuba Sienieńskiego. W roku następnym małżonkowie Myszkowscy weszli w posiadanie majętności wrzawskiej w powiecie urzędowskim. Połowę tych dóbr nabył podczaszy lubelski od Mikołaja Sienieńskiego, który przed aktami ziemskimi urzędowskimi zeznał, że przekazał je szwagrowi modo donatorio. Pozostałe połowy wsi Wrzawy, Goczałkowice, Strachocin i Białkowice darował $z$ kolei Katarzynie $z$ Sienna w ziemstwie przemyskim jej drugi brat, Jakub Sienieński. Dnia 16 lipca 1602 r. podczaszyna lubelska zawarła $z$ nim jednak umowę, na mocy której zastawiła mu swoja połowę klucza wrzawskiego za sumę 5000 florenów (oblata w ziemstwie lubelskim 3 lutego 1603 r.). Wydawać by się mogło, że uregulowano w ten sposób wszystkie pretensje majątkowe, jakie Myszkowscy mogliby wysuwać wobec braci Katarzyny. Tak jednak nie było. Podczaszy lubelski nie potrafił bowiem

[dalej: Urzednicy lubelscy], oprac. W. Kłaczewski i W. Urban, red. A. Gassiorowski, Kórnik 1991, nr 165; A. Strzelecki, Sejm z r. 1605, Kraków 1921, s. 21, 62; APL, LZW, nr 87, k. 644v-647 (tu akt podziału klucza bychawskiego); Rejestr lubelski 1626, s. 66-67; B.H. Łuszczyński, op. cit., t. V, s. 447 (tu informacja o obu żonach Stanisława Myszkowskiego; podano jednak błędna datę jego śmierci rok 1623). Nie udało się niestety znaleźć bezpośredniego potwierdzenia faktu, że żona Stanisława Myszkowskiego była Zofia Borkówna z Pawłowic. Niemniej jednak w moim przekonaniu tylko ta Zofia z Trzcieńca mogła wyjść za podczaszego lubelskiego. Por. Archiwum Narodowe w Krakowie [dalej: ANK], Castriensia Cracoviensia Inscriptiones [dalej: CCI], nr 89, s. 1653-1654; nr 90, s. 717; nr 107, s. 12-13, 17, 53, 75-76, 150-155, 397-399, 582-583, 689-697, 1433-1434, 1653-1654, 1711-1714; nr 112, s. 860-865. Por. też Z. Anu sik, op. cit., s. 260-261. 
ułożyć sobie stosunków ze szwagrami i toczył z nimi nieustające spory, których nie zdołał zakończyć do śmierci ${ }^{31}$.

W drugiej połowie 1604 r. podczaszy lubelski Stanisław Myszkowski i jego żona, Katarzyna z Sienna sprzedali dobra Wrzawy Marcinowi Gniewoszowi $z$ Wnorowa i jego żonie, Annie Leskiej z Leszczy. Dnia 3 stycznia 1605 r. Samuel Sienicki, działając w imieniu Stanisława Myszkowskiego, oblatował umowę sprzedaży tych dóbr w grodzie lubelskim. Sumę sprzedaży ustalono na 10 tys. florenów, przy czym 5000 florenów za połowę wsi Wrzawy, Goczałkowice, Strachocin i Białkowice Gniewosz miał przekazać Myszkowskim 18 stycznia 1605 r., a za kolejne 5000 florenów miał wykupić druga połowę dóbr wrzawskich z zastawu od Jakuba Sienieńskiego ${ }^{32}$. W 1607 r. małżonkowie Myszkowscy prowadzili spory prawne ze Zbigniewem Sienieńskim $z$ Chrośliny oraz z potężnym magnatem, kasztelanem krakowskim Januszem ks. Ostrogskim. Zakończenia tej drugiej sprawy nie dożył Stanisław Myszkowski, który zmarł przed 26 czerwca 1608 r. ${ }^{33}$

Po śmierci trzeciego męża Katarzyna $z$ Sienna samodzielnie gospodarowała $\mathrm{w}$ swoich dobrach $\mathrm{w}$ województwach lubelskim i ruskim. Więcej czasu spędzała teraz w ziemi przemyskiej, pozostawiając klucz boiski, który trzymała na mocy zapisów podczaszego lubelskiego, w rękach zarządców i dzierżawców. Jako wdowa, Myszkowska toczyła w 1612 r. proces $z$ Marcinem Sienieńskim z Mazanowa. W 1614 r. musiała $z$ kolei odpierać pretensje przyrodniej siostry - Zofii Sienieńskiej, wówczas żony Stanisława Pacanowskiego, do Boisk, Grabówki i Woli Sosnowej oraz do majętności

${ }^{31}$ Por. APL, LZS, nr 51, k. 368v-371v (tu Paweł Wierzbicki jako dziedzic Bychawy); AGAD, MK 147, f. 53. Co ciekawe, w akcie cesji Wrocanki na rzecz Jakuba Sienieńskiego Katarzyna $z$ Sienna występuje jako żona stolnika przemyskiego Jana Biejkowskiego, o śmierci którego brakuje jakiejkolwiek wzmianki. APL, LZWZ, nr 106, k. 428v-430v; LGR, nr 36, k. 204-205, 229v-230v, 779-780v, 1029-1029v; nr 37, k. 584v-585, 943v-944v (tu 21 XII 1607 r. ostatnia znana wzmianka o Stanisławie Myszkowskim jako o osobie żyjącej); nr 46, k. 1107$1108 \mathrm{v}$. Warto dodać, że na podstawie miejsc składania pozwów przeciwko uczestnikom sporu możemy stwierdzić, że główną siedziba podczaszego lubelskiego były Boiska, Mikołaja Sienieńskiego Ulhówek w województwie bełskim, a Jakuba Sienieńskiego - Wrzawy. Por. też Z. Anu sik, op. cit., s. 261-263.

32 Por. APL, LGR, nr 36, k. 489v-491.

${ }^{33}$ Por. APL, LGR, nr 37, k. 71-72v, 583v-584v. W kwestii przybliżonej daty śmierci Stanisława Myszkowskiego por. Urzędnicy lubelscy, nr 165. Por. też Z. Anusik, op. cit., s. 265. 
wrzawskiej. W 1616 r. podczaszyna lubelska procesowała się o ten ostatni majątek $z$ inną Zofią Sienieńską, jedyną córką nieżyjącego już brata Jakuba. W 1618 r. Katarzyna $z$ Sienna toczyła spory graniczne ze Zbigniewem Sienieńskim z Chrośliny i z Marcinem Sienieńskim z Mazanowa. W listopadzie 1618 r. Jan Myszkowski, pasierb Katarzyny, zniszczył kopce oraz wyciąl ocechowane drzewa na granicy między Boiskami a Mazanowem. Rzecz jasna Marcin Sienieński, dziedzic tego ostatniego majątku, zareagował pozwem przeciwko niemu, jego przyrodniemu bratu Maurycemu oraz macosze. Wkrótce potem Jan Myszkowski dokonał zbrojnego zajazdu dworu i folwarku w Boiskach oraz folwarków w Grabówce i Woli Sosnowej. Dnia 24 listopada 1618 r. podczaszyna lubelska złożyła skargę na poczynania pasierba w grodzie lubelskim. Odwołała się też do Trybunału Koronnego, który na sesji w Piotrkowie 13 grudnia tego roku wyjął Jana Myszkowskiego spod prawa, ogłaszając go infamisem. Myszkowski dwukrotnie wystarał się jednak o salvum conductum $\mathrm{z}$ kancelarii królewskiej, co uniemożliwiało egzekucję tego wyroku. Nie wiadomo, jak dalej potoczyłaby się ta sprawa, gdyby nie śmierć Katarzyny z Sienna Myszkowskiej, która zmarła przed 17 sierpnia 1619 r. ${ }^{34}$

Myszkowska pozostawiła po sobie troje dzieci: Zuzannę Ostrowską oraz Annę i Maurycego Myszkowskich. Jeszcze za życia matki jej najstarsza córka poślubiła Jerzego $z$ Konar Kochanowskiego h. Korwin. Jej mąż w 1620 r. został stolnikiem sandomierskim, a w lutym 1625 r. awansował na senatorski urząd kasztelana małogoskiego. Zmarł przed 10 marca 1633 r. Zuzanna przeżyła męża. Żyła jeszcze w 1637 r. Daty jej śmierci nie znamy. Anna Myszkowska w 1614 r. rozpoczęła nowicjat w zakonie norbertanek na podkrakowskim Zwierzyńcu. Została zabita w 1657 r. przez Kozaków, którzy dotarli do Krakowa $z$ wojskami księcia siedmiogrodzkiego Jerzego II Rakoczego. Jedyny syn podczaszyny lubelskiej, Maurycy Myszkowski na mocy ugody z przyrodnim bratem Janem objał w posiadanie odziedziczone po ojcu dobra boiskie. Zmarł jednak bezżennie i bezpotomnie w marcu 1624 r. $^{35}$

${ }^{34}$ Por. APL, LGR, nr 42, k. 195-195v; nr 44, k. 547v-550v, 643v-647, 653v655; nr 46, k. 1107-1108v; nr 48, k. 201-202, 797-798, 802-803, 805v-806v; nr 49, k. 396-397v, 567v-569v, 623-624, 754v-756, 996v-998 (tu oblata dekretu Trybunału Koronnego z 23 XI 1619 r. kasującego wyrok infamii na Jana Myszkowskiego). Por. też Z. Anu sik, op. cit., s. 266-269.

${ }^{35}$ Por. B.H. Łuszczyński, op. cit., t. IV, s. 120, 123; t. V, s. 447 (tu jednak brakuje wzmianki o Maurycym Myszkowskim); A. Przyboś, Kochanowski 
Zofia Sienieńska była najmłodszą córką Stanisława z Boisk i jednocześnie jedynym jego dzieckiem z drugiej żony, Agnieszki Marcinowskiej. W październiku 1614 r. ta właśnie Zofia, wówczas już żona Stanisława Pacanowskiego h. Jelita, wystapiła $z$ pozwem przeciwko swojej przyrodniej siostrze Katarzynie z Sienna Myszkowskiej oraz jej synowi i pasierbowi, żądając intromisji do Boisk, Grabówki i Woli Sosnowej. Pacanowska twierdziła, że Stanisław Sienieński zapisał jej matce, Agnieszce z Marcinowskich 2000 florenów tytułem długu na Woli Sosnowej. Domagała się też wypłacenia 7000 florenów za 13 lat użytkowania dóbr boiskich przez Myszkowskich oraz 20 tys. florenów odszkodowania za niewypłacenie jej posagu i niepodzielenie dóbr po ojcu pomiędzy wszystkie dzieci Stanisława. Zaopatrzeni w stosowny dekret sadu grodzkiego, Pacanowscy podjęli nawet próbę intromisji do Boisk, ale nie dopuścił do tego dzierżawca tych dóbr, Jakub Maszowski. W tym samym czasie Zofia $z$ Sienna Pacanowska wystapiła również z pretensjami do należącej niegdyś do jej ojca majętności wrzawskiej, ale $\mathrm{i}$ tu spotkało ja niepowodzenie. Warto jednak odnotować, że strona pozwana $\mathrm{w}$ sprawie dóbr sprzedanych przed 10 laty przez Stanisława i Katarzynę Myszkowskich była m.in. ta ostatnia. W grudniu 1614 r. w aktach grodzkich lubelskich pojawiła się jeszcze protestacja woźnego przeciwko niedopuszczeniu przez Myszkowskich do intromisji w Boiskach. W ostatecznym rozrachunku spadkobiercy podczaszego lubelskiego odparli jednak lub też zaspokoili w jakiejś części pretensje Pacanowskich i utrzymali tę majętność w swoich rękach ${ }^{36}$. Dalsze losy Zofii z Sienna Pacanowskiej nie sa znane.

Jerzy z Konar, [w:] PSB, t. XIII, Wrocław-Warszawa-Kraków 1967-1968, s. 193; Urzędnicy województwa sandomierskiego XVI-XVIII wieku. Spisy, oprac. K. Chłapowski i A. Falniowska-Gradowska, red. A. Gąsiorowski, Kórnik 1993, nr 158, 917; K. Niesiecki, op. cit., t. VI, Lipsk 1841, s. 500 (tu jednak brakuje informacji o Annie Myszkowskiej); M. Borkowska, Zakonnice pominięte $w$ tablicach Dworzaczka, „Nasza Przeszłość” 2002, t. XCVII, s. 282. Por. APL, LGR, nr 49, k. 754v-756; nr 54, k. 270v-272; LZWZ, nr 108, k. 481-481v. Warto dodać, że po śmierci Maurycego Myszkowskiego jego przyrodnie rodzeństwo, Zuzanna Kochanowska i Jan Myszkowski, rozpoczęło długotrwała batalię o dobra boiskie. Ostatecznie, po zaspokojeniu pretensji Zuzanny, Boiska, Grabówkę i Wolę Sosnowa objął w posiadanie Jan Myszkowski, który od 1632 r. występuje już stale w źródłach jako dziedzic tego klucza. Więcej na ten temat por. Z. A nusik, op. cit., s. 269-272.

${ }^{36}$ Por. APL, LGR nr 44, k. 547v-550v, 643v-647, 653v-655. Por. też Z. Anusik, op. cit., s. 266-267. 
Mikołaj Sienieński był jednym z dwóch synów Stanisława z Boisk i Niszczyckiej. Najpewniej jeszcze za życia ojca otrzymał dobra po matce w województwie bełskim. Dnia 29 lutego 1596 r. podpisał bowiem laudum sejmiku przedsejmowego w Bełzie w sprawie niesądzenia roków ziemskich w tym mieście. Był także uczestnikiem zjazdu szlachty województwa bełskiego zgromadzonej podczas kadencji trybunalskiej w Lublinie w czerwcu 1599 r. Był właścicielem miasta Uhnów oraz wsi Ulhówek w województwie bełskim. Jako właściciel tej ostatniej, w 1596 r. Mikołaj Sienieński toczył spory prawne $z$ kanclerzem wielkim koronnym Janem Zamoyskim, który bezpodstawnie oskarżył go o naruszenie granic użytkowanej przez siebie królewskiej wsi Rzeczycy należącej do starostwa bełskiego. Po śmierci ojca Mikołaj objął połowę dóbr wrzawskich w województwie lubelskim, a więc połowę Wrzaw, Strachocina, Goczałkowic i Białkowic. W 1602 r. sprzedał jednak te dobra (formalnie przekazał je modo donatorio) swojemu szwagrowi, podczaszemu lubelskiemu Stanisławowi Myszkowskiemu. Z tym ostatnim zawarł jakąs umowę pod zakładem 1420 florenów. Później zaś procesował się $z$ nim o niedotrzymanie warunków tej intercyzy. W 1607 r. starał się o przeniesienie długu, którym obciążyła Uhnów jego siostra, Anna $z$ Sienna Żukowska na dobra dziedziczne jej męża, czyli wieś Sobianowice w województwie lubelskim. Z Żukowska zawarł jakąś umowę pod zakładem 17 tys. florenów. Wspierał także tę siostrę, a później jej dzieci w procesie $z$ Krzysztofem Grekiem o część wsi Rybczyce. Rezydował głównie we wsi Ulhówek, gdzie składano skierowane przeciwko niemu pozwy. Nie wiadomo, czy kiedykolwiek się ożenił. $Z$ cała pewnością zmarł bezpotomnie, gdyż Ulhówek przeszedł następnie w ręce jego bratanicy. Nie znamy niestety daty śmierci Mikołaja Sienieńskiego. Nie żył on już jednak na pewno w 1616 r. $^{37}$

Jakub Sienieński był drugim synem (zapewne młodszym) Stanisława Sienieńskiego $z$ Boisk i Niszczyckiej, rodzonym bratem Mikołaja, Katarzyny i Anny, a przyrodnim Zofii. Zapewne jeszcze za życia ojca uzyskał jakiś udział w dobrach macierzystych w województwie bełskim. Po jego śmierci objałł w posiadanie połowę dóbr

${ }^{37}$ Por. Akta sejmikowe województwa bełskiego. Lata 1572-1655, wyd. M. Zwierzykowski i R. Kołodziej, Kraków 2020, s. 137, 144; A. Tarnawski, op. cit., s. 83; LGR, nr 36, k. 204-205, 1029-1029v; nr 37, k. 386v-387, 584v-585, 715-715v, 783, 943v-944v; nr 46, k. 1107-1108v. Por. też Z. Anusik, op. cit., s. $252,263$. 
wrzawskich. W 1601 r. na mocy konsensu królewskiego od swojej siostry, podczaszyny lubelskiej Katarzyny Myszkowskiej przejął królewską wieś Wrocanka (wraz z wójtostwem) w ziemi sanockiej. $\mathrm{W}$ roku następnym odprzedał tejże siostrze (formalnie darował) swoja część Wrzaw, Goczałkowic, Strachocina i Białkowic. Dnia 16 lipca 1602 r. Katarzyna $z$ Sienna Myszkowska zawarła z nim jednak umowę, na mocy której zastawiła mu swoją połowę klucza wrzawskiego za sumę 5000 florenów (oblatowano ją w ziemstwie lubelskim 3 lutego 1603 r.). Jakub musiał jednak ustapić z majętności wrzawskiej w 1605 r., gdy małżonkowie Myszkowscy sprzedali Wrzawy z przyległościami Marcinowi Gniewoszowi z Wnorowa i jego żonie, Annie Leskiej z Leszczy, upoważniając ich do wykupienia zastawionej części tego klucza. Być może w tym samym czasie Sienieński zawarł jakąś umowę ze swoim szwagrem, podczaszym lubelskim Stanisławem Myszkowskim pod zakładem 4700 florenów, później zaś procesował się $z$ nim o niedotrzymanie warunków tego układu. Po ustapieniu $z$ Wrzaw przeniósł się do Wrocanki. Jakub Sienieński założył rodzinę, ale brakuje jakichkolwiek informacji o jego małżonce. Pozostawił po sobie jedynie córkę Zofię, która była spadkobierczynia zarówno ojca, jak i stryja Mikołaja. Nie znamy daty śmierci Jakuba. Nie żył on już jednak na pewno w roku $1616^{38}$.

W tym bowiem roku Zofia Sienieńska, córka nieżyjącego już Jakuba, działając wspólnie ze swoimi opiekunami, wystąiła z pretensjami do Wrzaw i innych wiosek tego klucza. Jan i Maurycy Myszkowscy, jako synowie podczaszego lubelskiego Stanisława, byłego właściciela Wrzaw z przyległościami, 17 grudnia $1616 \mathrm{r}$. pozwali Zofię o bezpodstawne roszczenia do tego majatku. Przy tej okazji wyjaśniono okoliczności przejmowania dóbr wrzawskich przez kolejnych właścicieli. Jan i Maurycy Myszkowscy stwierdzili, że połowę tego majątku przekazał ich ojcu modo donatorio nieżyjący już stryj Zofii, Mikołaj Sienieński. Stanisław Myszkowski $z$ kolei darował te dobra swojej żonie, a ta (również $\mathrm{w}$ formie darowizny) przekazała je Annie z Leskich Gniewoszowej, od której otrzymał Wrzawy Aleksander Słupecki Grot. Z pozwem przeciwko bratanicy wystapiła także Katarzyna $z$ Sienna Myszkowska, która zeznała, że otrzymała połowę majętności wrzawskiej od ojca Zofii,

38 Por. AGAD, MK 147, f. 53; APL, LZWZ, nr 106, k. 428v-430v; LGR, nr 36, k. 204-205, 229v-230v, 489v-491, 779-780v; nr 46, k. 1107-1108v. Por. też Z. Anusik, op. cit., s. 263, 267. 
Jakuba Sienieńskiego. Będąc zaś, po rezygnacji z drugiej połowy tego klucza przez męża, właścicielką całych Wrzaw z przyległościami, odstąpiła je Annie $z$ Leskich Gniewoszowej, od której przeją je Aleksander Słupecki Grot. Dnia 25 czerwca 1626 r. został on pozwany przez spadkobierców nieżyjącej już Zofii z Sienna Siedleszczyńskiej, córki Jakuba, tenutariusza Wrocanki. O należną jej jakoby część majętności wrzawskiej, stanowiącej w rozumieniu powodów spadek po Jakubie i Mikołaju Sienieńskich, upomniał się wdowiec Stanisław w imieniu własnym oraz dwójki osieroconych przez Zofię dzieci, Benedykta i Anny Siedleszczyńskich ${ }^{39}$.

Średni syn kasztelanica małogoskiego Wiktoryna Sienieńskiego - Jakub pod koniec 1563 lub też na początku 1564 r. ożenił się z Reginą Czerną z Witowic, córką Jerzego, stolnika lubelskiego, a siostra jego szwagra Pawła (męża Zofii z Sienna). Dnia 17 stycznia 1564 r. Jakub Sienieński z Chrośliny i Glinnika oprawił żonie 3000 florenów posagu, a ta ustapiła $z$ dóbr na rzecz braci Pawła, Jerzego, Piotra i Stanisława Czernych. Tego samego dnia małżonkowie Sienieńscy zeznali zapis wzajemnego dożywocia na wszystkich dobrach nieruchomych i ruchomych ${ }^{40}$. Dnia 3 maja $1571 \mathrm{r}$. Sienieński przeprowadził dział dóbr po ojcu z braćmi Stanisławem i Janem. Objął wówczas w posiadanie Mazanów, Wałowice, Wolę Lubaszowa, Prawno, Glinnik, Ocierchów, Skowierzyn oraz Radomyśl w powiecie urzędowskim. W 1581 r. Sienieński wziął udział, jako poseł województwa lubelskiego, w sejmie zwyczajnym obradujaccym w Warszawie. W tym samym roku uzyskał dla Radomyśla prawa miejskie. Na początku lat dziewięćdziesiątych potwierdził, że jest winien swojemu bratankowi, Zbigniewowi Sienieńskiemu z Chrośliny 3000 florenów. W 1595 r., jako właściciel Wałowic i Mazanowa, prowadził spory $z$ Prokopem Ossolińskim oraz $z$ Krzysztofem ks. Radziwiłłem o zbiegłych poddanych. Pozywał także biskupa krakowskiego Jerzego ks. Radziwiłła, którego poddani spustoszyli lasy należące do Mazanowa. W roku następnym procesował się $z$ bratankiem, Zbigniewem $z$ Chrośliny o kwotę 1200

39 Por. APL, LGR, nr 46, k. 1107-1108v; nr 55, k. 688-689v. Warto zwrócić uwage na to, że pozwy przeciwko Zofii Sienieńskiej złożono w 1616 r. we wsi Ulhówek, która była niegdyś własnościa jej stryja Mikołaja. Rzecz jasna zarówno roszczenia Zofii, jak i jej dzieci do klucza wrzawskiego były pozbawione jakichkolwiek podstaw. Bez większych problemów zostały też odparte przez prawowitego właściciela Wrzaw i Strachocina, Aleksandra Słupeckiego Grota. Por. Rejestr lubelski 1626, s. 92; oraz Z. Anusik, op. cit., s. 267.

${ }^{40}$ Por. APL, LZW, nr 83, k. 467-469v; Z. Anusik, op. cit., s. 250-251. 
florenów. Po śmierci pierwszej żony Reginy Jakub Sienieński ożenił się ponownie $z$ Barbara Pacanowska h. Jelita, która go przeżyła i po owdowieniu wyszła ponownie za mąz - za Stanisława Samborzeckiego h. Rawicz, dziedzica na Ostrowie i Bochotnicy. Pamiętnikarz Jakub Pszonka odnotował, że Sienieński zmarł w 1601 r. $Z$ pierwszego małżeństwa miał synów Marcina i Abrahama oraz córkę Elżbietę ${ }^{41}$. Drugie małżeństwo Jakuba było bezdzietne.

Elżbieta, jedyna córka Jakuba Sienieńskiego i Reginy Czernej, przez długie lata procesowała się $z$ własnym bratem Marcinem. W 1612 r., w asyście swoich opiekunów, złożyła w grodzie lubelskim skarge o niewydzielenie jej należnej części dóbr ojcowskich i odmowę wypłacenia posagu. Marcin odpowiedział pozwaniem opiekunów Elżbiety, w tym podskarbiego wielkiego koronnego i starosty lubelskiego Jana Firleja, któremu zarzucił niesprawiedliwe ferowanie dekretu na korzyść siostry (przez kilka lat ciążył na Sienieńskim wyrok banicji). W 1617 r. sad grodzki lubelski przyznał Elżbiecie, wówczas już żonie Adriana Mikołajewskiego, prawo intromisji do Mazanowa, uznając zasadność jej pretensji do kwoty 5000 florenów. Niesnaski między rodzeństwem postanowił wykorzystać kasztelan krakowski Janusz ks. Ostrogski, który zmierzając do zakupienia jakichś dóbr w województwie lubelskim, upatrzył sobie należące do Sienieńskich wsie Wałowice i Mazanów (w 1607 r. dzierżawił nawet pierwszą $z$ tych wiosek, skąd jego zarządca dokonał zbrojnej napaści na włość boiską należącą do podczaszego lubelskiego Stanisława Myszkowskiego). W 1617 r. Elżbieta $z$ Sienna Mikołajewska, nie mogac wyegzekwować od brata należnych jej pieniędzy, sprzedała kasztelanowi krakowskiemu Wałowice i Mazanów za 40 tys. florenów. Transakcja ta została jednak dokonana $z$ ewidentnym pogwałceniem obowiązującego

${ }^{41}$ Por. APL, LGR, nr 55, k. 539-539v; W. Sokołowski, op. cit., s. 183; Posłowie ziemscy, s. 268; R. Szczygiel, Nie zrealizowana lokacja Chocimowa $w$ województwie lubelskim. O wpływach sporów granicznych na powstanie miast, „Roczniki Humanistyczne” 1987, t. XXXV, z. 2, s. 286; Pamiętnik Jakuba Pszonki $z$ autografu $w$ bibliotece Ossolińskich znajdujacego sie wydany. Inwentarz Skarbu Koronnego z roku 1607, wyd. A. Bielowski, Lwów 1874, s. 29; Z. A nu sik, op. cit., s. 251; APL, LGR, nr 30, s. 493-494, 1251, 1330-1331, 2240-2241, 2311, 23762377; Lubelskie ziemskie, Zobowiazania [dalej: LZZ], nr 102, k. 836-836v; LZS, nr 54, k. 111v-113 (Marcin Sienieński, syn zmarłego Jakuba przeciwko Stanisławowi Samborzeckiemu i jego żonie Barbarze Pacanowskiej, wdowie po Jakubie Sienieńskim); LGR, nr 42, k. 213 (tu wspomniana Elżbieta, córka zmarłego Jakuba), k. 295v-296, 342v-343 (Pacanowscy pozywaja braci Marcina i Abrahama Sienieńskich z Mazanowa i Wólki Mazanowskiej). 
prawa. Obie wsie należały bowiem do Marcina Sienieńskiego, który wcale nie zamierzał $z$ nich ustapić. Pociagnęło to za sobą kolejne procesy $z$ udziałem Ostrogskiego, Marcina i Abrahama Sienieńskich, żony Marcina, Katarzyny z Bobrku Ligęzianki, której oprawa została zabezpieczona m.in. na Wałowicach i Mazanowie, oraz Adriana i Elżbiety z Sienna Mikołajewskich. Ostatecznie sprawę tę uregulowano w 1619 r. w ten sposób, że Marcin Sienieński zrezygnował na rzecz kasztelana krakowskiego $z$ Wałowic, ale zatrzymał w swoich rękach Mazanów. Nie wiemy niestety, jak wyglądało ostateczne rozliczenie należności za sporne dobra między Ostrogskim, Sienieńskim i Elżbieta z $z$ Sienna Mikołajewską. Ta ostatnia, po śmierci pierwszego męża, jeszcze dwukrotnie wychodziła za mąż, najpierw za Jana Białyńskiego, a następnie za Piotra Minockiego ${ }^{42}$.

Wspominany już kilkakrotnie Marcin Sienieński był starszym synem Jakuba i Reginy Czernej. Po śmierci ojca objął w czasowe posiadanie wszystkie należące do niego dobra. Po przeprowadzeniu działów $z$ bratem Abrahamem wzią natomiast Wałowice, Mazanów, Wolę Lubaszową (Wólkę Mazanowska), Prawno i połowę miasteczka Radomyśla. W 1605 r. procesował się ze Stanisławem Samborzeckim $z$ Bochotnicy, drugim mężem swojej macochy, o sumy zapisane Barbarze Pacanowskiej przez Jakuba Sienieńskiego na Wałowicach i Woli Lubaszowej. Najpewniej to on był tym Marcinem z Sienna Sienieńskim, który w maju 1607 r. znalazł się w składzie poselstwa wysłanego do Zygmunta III i zbierającego się w Warszawie sejmu przez zgromadzona na rokosz pod Wąchockiem szlachtę. Dnia 13 czerwca tego roku podpisał też w obozie pod Czerskiem „Uniwersał na konkludowanie rokoszu”. W 1608 r., przy okazji kolejnego procesu z Samborzeckimi, odnotowano, że pierwszą, nieżyjąca już żona Marcina była Bernardyna Dorota Zarembianka $z$ Kalinowy h. Zaremba, córka Andrzeja, starosty grabowskiego i Ślązaczki, Bernardyny von Maltzan $z$ Sycowa. Wspomniano również o trójce urodzonych przez nią dzieci: Joachimie, Janie i Mariannie oraz o drugiej żonie Marcina, Katarzynie Ligęziance z Bobrku, córce Jana, wojskiego sanockiego. W 1612 r. Marcin Sienieński pozywał Myszkowskich z Boisk o bezprawne zajęcie części gruntów należących do Mazanowa. W tym samym czasie próbował zaspokoić pretensje spadkobierców swojej macochy: Stanisława,

${ }^{42}$ Por. APL, LGR, nr 42, k. 213, 513v-514v; nr 47, k. 871v-872, 1118-1120v; nr 48, k. 608v-610; nr 49, k. 198-199v, 846-848v; B.H. Łuszczyński, op. cit., t. VII, s. 263. 
Jana i Andrzeja Pacanowskich, synów nieżyjącego już Andrzeja, pozywając ich o to, że nie chca przystać na spłatę 4000 florenów zabezpieczonych na Mazanowie i Woli Lubaszowej. W lipcu tego roku nie dopuścił też (działając razem $z$ bratem Abrahamem) do intromisji Pacanowskich, wyposażonych w stosowny dekret sadu grodzkiego, do Mazanowa. Warto wreszcie odnotować, że z 12 lipca 1612 r. pochodzi pierwsza wzmianka o tym, że wieś Prawno uzyskała prawa miejskie. Założenie tego miasteczka było więc niewątpliwie dziełem Marcina Sienieńskiego. Należy także przypomnieć, że w 1612 r. rozpoczął się omówiony już spór Marcina $z$ jego siostrą Elżbieta, który trwał nieprzerwanie do roku $1619^{43}$.

W 1616 r. Marcin Sienieński pozywał Jakuba Pszonkę o nasłanie sług i poddanych na Wolę Lubaszowa. Szkody wyrządzone przez nich w tej wsi wycenił na 10 tys. grzywien. Tego samego Pszonkę skarżył w roku następnym o odebranie siłą wsi Świeciechów, należącej do biskupa i kapituły krakowskiej, którą dzierżawiła jego żona, Katarzyna $z$ Bobrku Sienieńska. Z Myszkowskimi $z$ Boisk procesował się Marcin o młyn w tej wiosce oraz o granice między Mazanowem a Boiskami. W 1618 r. Katarzyna z Sienna Myszkowska oskarżyła właściciela Mazanowa o szkody w należącym do majętności boiskiej lesie, w którym ludzie Marcina wycięli podobno aż 5000 drzew. Spór ten uległ gwałtownej eskalacji jesienia tego roku. Dnia 6 listopada 1618 r. komornik graniczny lubelski Andrzej Sługocki dokonał rozgraniczenia Boisk i Mazanowa. Wyznaczona przez niego granica nie znalazła jednak uznania w oczach właścicieli dóbr boiskich. Jan Myszkowski na czele hajduków, kozaków i tłumu poddanych zniszczył bowiem 83 kopce graniczne i wycią 50 ocechowanych drzew w lesie na granicy obu majątków. Rzecz jasna Marcin Sienieński zareagował pozwem przeciwko dziedzicom Boisk, Janowi i Maurycemu Myszkowskim oraz przeciwko posesorce tego klucza, Katarzynie $z$ Sienna Myszkowskiej, podczaszynie lubelskiej. Nie znamy niestety daty śmierci Marcina Sienieńskiego. Po raz ostatni jako żywy został on wspomniany $\mathrm{w}$ księdze relacji akt grodzkich lubelskich 30 września

${ }^{43}$ Por. APL, LGR, nr 36, k. 524, 526v; nr 42, k. 195-195v, 296, 342v-343; V. Urbaniak, Zamoyszczycy bez Zamoyskiego. Studium dekompozycji ugrupowania politycznego, Warszawa 1995, s. 100, 105; APL, LZS, nr 54, k. 111v-113 (tu informacja o obu żonach i dzieciach Marcina Sienieńskiego pochodzących z jego małżeństwa z Bernardyną Dorota Zarembianka); R. Szczygieł, op. cit., s. 286 (tu jednak błędna informacja, że miasteczko Prawno zostało założone przez Jana Abrahama Sienieńskiego). 
1619 r. Nie żył już zaś na pewno w momencie, kiedy wdowa po nim, Katarzyna z Bobrku Sienieńska oblatowała w ziemstwie lubelskim umowę $z$ małżonkami Janem i Zofią Dąbrowskimi, na mocy której zastawiła im miasteczko Prawno i wieś Mazanów. Ponieważ jednak nie wpisano tu daty tej transakcji, możemy jedynie stwierdzić, że miało to miejsce między datami granicznymi wpisów w tej księdze, czyli po 5 stycznia 1621 a przed 2 stycznia $1623 \mathrm{r}$. W moim przekonaniu śmierć Marcina Sienieńskiego musiała jednak nastąpić najpóźniej w końcu 1621 lub też na początku 1622 r. ${ }^{44} \mathrm{Z}$ małżeństwa $z$ Bernardyna Dorota Zarembianka miał Marcin synów Joachima, Jana (Jana Abrahama) i córkę Mariannę. Z drugiego małżeństwa, $z$ Katarzyna $z$ Bobrku Ligęzianka, pozostawił natomiast trzy córki: Zofię, Katarzynę i Annę $e^{45}$.

Drugim, młodszym synem Jakuba i Reginy Czernej był Abraham. $Z$ pewnością był to człowiek obdarzony zdecydowanie mniejszym temperamentem niż jego brat Marcin. Bardzo rzadko był odnotowywany w lubelskich księgach relacji. Występował głównie jako uczestnik sporów i procesów prowadzonych przez starszego brata. $Z$ cała pewnościa był natomiast bardzo rzadnym gospodarzem. $Z$ działów dóbr po ojcu przypadła mu w udziale połowa miasta Radomyśl oraz wsie Nowiny, Glinnik, Ocierchów i Skowierzyn. Dnia 27 stycznia 1623 r. Abraham Sienieński spisał w grodzie lubelskim akt dożywocia z żoną, Agnieszką Rokoszówną h. Ostoja. Zabezpieczył jej wówczas prawo dożywotniego użytkowania połowy Radomyśla, folwarku w Nowinach oraz wsi Ocierchów, Glinnik i Świekozy (ostatnia wioska leżała w województwie sandomierskim i pozostawała ówcześnie prawdopodobnie w zastawie Abrahama). W tym samym czasie Sienieński uzyskał intromisję do Starej Wsi i Wólki w województwie sandomierskim. Obie wsie stanowiły własność Krzysztofa Młodziejowskiego, który był winien Abrahamowi 7000 florenów. W rejestrze poborowym województwa lubelskiego z 1626 r. odnotowano własność Sienieńskiego w Radomyślu oraz we wsiach Glinnik, Ocierchów i Skowierzyn. W spisie tym pominięto wieś Nowiny, która także była wówczas własnością Abrahama. W 1629 r. do Sienieńskiego należała również trzecia część dużej wsi Brzeziny (miał w swojej części nieco ponad 5 łanów)

44 Por. APL, LZS, nr 60, k. 903v-904; LGR, nr 47, k. 280v-282v, 301-302v, 792v-793, 797-798; LZWZ, nr 109, k. 194v-195.

45 Por. APL, LZS, nr 54, k. 111v-113 (tu o dzieciach z pierwszego małżeństwa); LGR, nr 59, k. 694-695 (tu o Zofii i Katarzynie); nr 113, k. 532-533 (tu o Annie). 
w powiecie pilzneńskim. Dnia 22 lutego 1633 r. uzyskał od Władysława IV (wraz $z$ bratankiem Janem Abrahamem) przywilej dla Radomyśla, w którym król zezwalał na urządzanie w tym mieście jarmarków 2 lutego, 25 lipca i 29 września oraz targów cotygodniowych w czwartki. Staraniem Abrahama w 1614 r. erygowano w Radomyślu parafię. W 1625 r. sprowadził on do tego miasta augustianów, którym ufundował klasztor i powierzył prowadzenie miejscowej parafii. Swoje dobra obciążył zapisami na rzecz radomyskich augustianów, którym zapewnił m.in. środki na utrzymanie kapeli w kościele parafialnym w Radomyślu. Nie znamy niestety daty śmierci Abrahama Sienieńskiego. Nie żył już jednak na pewno w 1639 r., gdy w panegiryku upamiętniającym szczęśliwy powrót $z$ zagranicznej podróży jego bratanka Jana Abrahama wśród jego dóbr dziedzicznych wymieniono wszystkie wioski należące wcześniej do Abrahama. $Z$ małżeństwa z Agnieszką Rokoszówną Sienieński nie doczekał się potomstwa. Wszystkie dobra po nim odziedziczył syn Marcina, Jan Abraham Sienieński ${ }^{46}$.

Marianna, jedyna córka Marcina i Bernardyny Doroty Zarembianki, została wspomniana w źródłach jedynie raz, w 1608 r. Najpewniej zmarła młodo, jeszcze przed śmiercia ojca. Zofia, jedna $z$ trzech córek Marcina i Katarzyny Ligęzianki, została zakonnica. Przyjąwszy imię Teresy, wstapiła do klasztoru brygidek w Lublinie, gdzie odnotowano jej obecność w 1623 r. Żyła jeszcze na pewno w 1630 r., kiedy wspomniano o niej w lubelskiej księdze relacji przy okazji sporu, jaki prowadził wówczas jej przyrodni brat Jan Abraham ze Zbigniewem Sienieńskim z Chrośliny. Do tego samego klasztoru w Lublinie wstapiła też Katarzyna, druga córka Marcina i Katarzyny Ligęzianki, która wśród brygidek znana była jako siostra Beata. Również o niej wspomniano w cytowanym już dokumencie z 1630 r. Niestety nic nie wiemy o dalszych losach Zofii seu Teresy ani też Katarzyny seu Beaty Sienieńskich. Trzecią córką Marcina i Katarzyny Ligęzianki była Anna. Tylko ona wyszła za mąż, poślubiwszy przed 1633 r. Wawrzyńca Kosa. Oboje małżonkowie zostali odnotowani w Metryce Koronnej 22 kwietnia 1638 r., gdy otrzymali konsens królewski na ustapienie $z$ wójtostwa we wsi

46 Por. APL, LGR, nr 53, k. 60-60v; nr 100, k. 648-649v; nr 102, k. 886-888; AGAD, MK 180, k. 55v-56; Rejestr lubelski 1626, s. 92-93, 108; Z. A nu sik, Struktura własności ziemskiej $w$ powiecie pilzneńskim $w$ roku 1629, „Przeglad Nauk Historycznych" 2011, R. X, nr 2, s. 98; K. Estreich er, Bibliografia staropolska, t. XXI, Kraków 1906, s. 77. 
Majków, należącej do starostwa piotrkowskiego na rzecz Andrzeja i Zuzanny Orwitowskich. Ze związku z Wawrzyńcem Kosem Anna z Sienna doczekała się dwojga dzieci - syna Jana Kazimierza oraz córki Teresy. Ta ostatnia dwukrotnie wychodziła za maż, najpierw za Jana Bębnowskiego, a następnie za Stanisława Głębockiego ${ }^{47}$.

Joachim, starszy syn Marcina i Bernardyny Doroty Zarembianki z Kalinowy, wspomniany tylko raz, w roku 1608, zmarł młodo i bezpotomnie. Ojca przeżył jedynie jego młodszy, rodzony brat - Jan Abraham. Nazwisko tego ostatniego, syna zmarłego już Marcina, pojawia się w księgach grodzkich lubelskich 30 czerwca 1622 r. przy okazji sporu o granice Mazanowa i Woli Lubaszowej, jaki toczył z Janem i Maurycym Myszkowskimi, właścicielami Boisk i Grabówki. W 1626 r. odnotowano własność Jana Abrahama w miasteczku Prawnie oraz we wsiach Mazanów i Wola Lubaszowa. Był on chyba jednak w tym czasie również właścicielem połowy miasta Radomyśla, z którego pobór w całości opłacił jego stryj Abraham. W $1627 \mathrm{r}$. Jan Abraham Sienieński kupił od Jerzego Pieniążka $z$ Krużlowej wieś Wrzosowice w powiecie krakowskim. Zobowiązał się przy tej okazji do spłaty 6000 florenów oprawy nieżyjącej już żony Jerzego Pieniążka, Katarzyny z Drzewieckich, zabezpieczonej przez niego na tej wsi. Pieniądze $z$ tego tytułu przekazywał poprzedniemu właścicielowi Wrzosowic w ratach przez kilka kolejnych lat. Spłacił też pretensje do części nowo nabytej wioski wysuwane przez Samuela i Annę z Młyńskich Sutkowskich. W 1629 r. Jan Abraham opłacił z Wrzosowic pobór od 3,5 łanu, 12 zagród, 6 komorników, 1 czynszownika i 1 koła młyńskiego ${ }^{48}$.

W styczniu 1629 r. Jan Abraham Sienieński ożenił się z Anną Gajowską h. Sulima. Była ona córką Andrzeja i młodszą siostrą Krystyny, od 1617 r. wdowy po kasztelanie oświęcimskim Aleksandrze

47 Por. APL, LZS, nr 54, k. 111v-113; LGR, nr 59, k. 694-695; nr 113, k. 116116v, 532-533; nr 114, k. 564v-565; M. Borkowska, op. cit., s. 292 (tu obie Sienieńskie występuja pod swoimi zakonnymi imionami. Jedynie w przypadku Teresy odnotowano, że była ona córka Marcina i Katarzyny Ligęzianki. W przypadku jej siostry Beaty brakuje jakichkolwiek danych); B.H. Łuszczyński, op. cit., t. VII, s. 263; AGAD, MK 185, k. 36v-37.

48 Por. APL, LGR, nr 52, k. 500v-501; Rejestr lubelski 1626, s. 92, 108; ANK, CCI, nr 227, s. 2251-2260, 2262, 2460-2462, 2543-2544, 2569-2572; nr 229, s. 457 ; nr 231, s. $1439-1440$; nr 234, s. 391-392; nr 235, s. 92-95; nr 237, s. 4849; nr 239, s. 56-57; Rejestr poborowy województwa krakowskiego z roku 1629 [dalej: Rejestr krakowski 1629], oprac. W. Domin, J. Kolasa, E. Trzyna, S. Żyga, red. S. Inglot, Wrocław 1956, s. 50 (tu jednak błędne nazwisko właściciela Wrzosowic - Siemieński zamiast Sienieński). 
Myszkowskim. Dnia 25 stycznia 1629 r. małżonkowie zapisali sobie wzajemnie dożywocie na wszystkich dobrach nieruchomych i ruchomych. Następnie Jan Abraham oprawił posag żony wynoszacy 6000 florenów, a Anna $z$ Gajowskich Sienieńska zeznała ustapienie na rzecz ojca $z$ wszelkich pretensji do dóbr ojczystych i macierzystych. W tym samym roku Jan Abraham skwitował Krystynę $z$ Gajowa Myszkowska z 500 florenów oraz zawarł ze szwagrem, dworzaninem królewskim Stanisławem Gajowskim, ostatecznie niezrealizowaną, umowę sprzedaży części Wrzosowic za 10 tys. florenów ${ }^{49}$. $\mathrm{Na}$ przełomie lat dwudziestych i trzydziestych XVII w. Sienieński dysponował sporymi zasobami gotówki. Udzielił bowiem wówczas znacznych pożyczek Mikołajowi Bębnowskiemu (1000 florenów), Stanisławowi i Jakubowi Chrząstowskim (1200 florenów), Andrzejowi i Annie Bogusławskim (2000 florenów) i Mikołajowi Jordanowi (1700 florenów). Wszystko wskazuje na to, że Jan Abraham planował przenieść się na stałe do województwa krakowskiego. Przed 1628 r. sprzedał bowiem za 30 tys. florenów miasteczko Prawno oraz wsie Mazanów i Wola Lubaszowa w powiecie urzędowskim swojemu stryjecznemu stryjowi, kasztelanowi lubelskiemu Zbigniewowi Sienieńskiemu ${ }^{50}$.

W 1631 r. Jan Abraham Sienieński uzyskał skwitowanie z należnych Kościołowi dziesięcin $z$ Wrzosowic. Już jednak w początkach 1632 r. kupił od Marcina Święcickiego za 16800 florenów wieś Rzeczycę Mała w powiecie urzędowskim. Najpewniej w związku $z$ ta transakcja zastawił Wrzosowice za 16 tys. florenów Zuzannie Koszyckiej, wdowie po Stanisławie. Pożyczył też niewielkie kwoty od Jerzego Gładysza (1200 florenów) i Wojciecha Dembińskiego (1000 florenów). Obie pożyczki dość szybko zresztą spłacił. Rozliczył się także $z$ części zobowiązania wobec Marcina Święcickiego (wypłacił mu w sumie w trzech ratach 5000 florenów), co ten ostatni potwierdził w grodzie krakowskim. Dnia 17 marca $1632 \mathrm{r}$. Jan Abraham Sienieński doprowadził do urzędowego wytyczenia granicy między Rzeczyca Mała (oraz Branwica i Bąkowcem) a należącymi do Jana i Stanisława Grodzkich Rzeczyca Okragła i Wolą Rzeczycką. Z kolei 22 lutego 1633 r. Sienieński uzyskał od Władysława IV (wraz ze stryjem Abrahamem) wspomniany już

49 Por. ANK, CCI, nr 229, s. 1451-1452, 1477-1478; nr 230, s. 635-637, 15491554; nr 231, s. 190.

50 Por. ANK, CCI, nr 228, s. 218-219, 270-272; nr 229, s. 456; nr 230, s. 10841086; nr 231, s. 1909-1910; APL, LGR, nr 57, k. 576v-578v; nr 59, k. 694-695. 
przywilej dotyczący urządzania jarmarków i targów w Radomyślu. W tym samym czasie (10 lutego) sprzedał Wrzosowice, wykupione $z$ zastawu od Zuzanny Koszyckiej, kanonikowi krakowskiemu Jakubowi Andrzejowi Kołaczkowskiemu. Transakcja ta pociagnęła za sobą konieczność przeniesienia oprawy posagu Anny z Gajowa na inne dobra. Tego samego dnia Sienieńska, działając w towarzystwie braci, Samuela Gajowskiego, plebana w Kazimierzy Wielkiej oraz Stanisława Gajowskiego, dworzanina królewskiego, skwitowała też męża $z$ wcześniejszych zapisów, a ten oprawił jej ponownie posag, tym razem w wysokości 7000 florenów. Po 1633 r. Jan Abraham Sienieński nie pojawił się już ani razu w grodzie krakowskim ${ }^{51}$.

Nie wiemy, co działo się z Janem Abrahamem przez kilka kolejnych lat. Po bezpotomnej śmierci stryja Abrahama odziedziczył on wszystkie jego dobra. W 1636 oraz w 1639 r. Sienieński dokonał kilku donacji na rzecz klasztoru augustianów w Radomyślu. Na podstawie pochodzacych $z$ późniejszego okresu źródeł możemy szacować, że Jan Abraham obciążył wówczas swoje dobra czynszami od kwoty około 6200 florenów. Zapisał również na swoim majątku czynsz od kwoty 2000 florenów na rzecz szpitala św. Hieronima w Sandomierzu. Pod koniec lat trzydziestych odbył podróż do Włoch. Jego powrót do kraju uczcił wydanym w 1639 r. panegirykiem radomyski augustianin Szymon Łaskarzovius. Jan Abraham został tu nazwany dziedzicem na Radomyślu, Nowinach, Glinniku, Skowierzynie i Rzeczycy. W 1641 r. doprowadził do urzędowego wytyczenia granicy między Rzeczyca Mała a wsią Lipa, stanowiąca własność ordynata Jana Zamoyskiego, starosty kałuskiego. Dalsze losy Jana Abrahama Sienieńskiego nie sa znane. Zmarł on prawdopodobnie w końcu roku 1647. Nie żył już na pewno 26 stycznia 1648 r., kiedy jego najstarszy syn Aleksander zawarł w Radomyślu

${ }^{51}$ Por. ANK, CCI, nr 233, s. 100-102; nr 235, s. 46-47, 88-91, 108; nr 237, s. 720-721, 784-790, 805-807, 839-840, 903, 988-990, 992-993; APL, LGR, nr 127, k. 1263-1264 (tu akt rozgraniczenia Rzeczycy Małej, Branwicy i Bakowca od Rzeczycy Okragłej i Woli Rzeczyckiej z 17 III 1632 r.); Rejestr lubelski 1626, s. 90 (tu w rękach Marcina Święcickiego część Rzeczycy Małej, w której odnotowano 2 łany, 2 zagrody i 2 koła młyńskie). Dodajmy w tym miejscu, że druga część tej wsi należała w 1626 r. do Anny Grodzkiej, wdowy po Jakubie. Można przypuszczać, że część Grodzkich z czasem zaczęto nazywać Reczycą Okrągłą. Niewielka wieś Branwica (Brandwica) była w tym czasie własnością Wojciecha Branwickiego. Por. ibidem, s. 90-91. Bąkowiec w ogóle nie został odnotowany w cytowanym rejestrze poborowym. 
jakaśs umowę z ciotka, Krystyna z Gajowa Myszkowską, kasztelanową oświęcimską ${ }^{52}$. $Z$ małżeństwa $z$ Anną Gajowską Jan Abraham Sienieński pozostawił synów Aleksandra, Abrahama i Jana oraz córki Krystynę, Mariannę i Izabelę.

Krystyna Sienieńska, najstarsza córka Jana Abrahama i Anny Gajowskiej, przed 1650 r. poślubiła Jana Piotraszowskiego. Była wdowa po nim w roku 1670, a żyła jeszcze w 1688 r. Marianna, średnia córka Jana Abrahama i Gajowskiej, w 1651 r. była już żona Aleksandra $z$ Więcborka Zebrzydowskiego h. Radwan. Owdowiała przed 1670 r., a żyła jeszcze w roku 1688. Izabela, najmłodsza córka Jana Abrahama Sienieńskiego i Anny z Gajowa, w roku 1670 była jeszcze panną. Wkrótce potem wyszła za mąż za Macieja Kozickiego, który zmarł w 1676 r. Po raz ostatni została wspomniana w księgach grodzkich lubelskich w roku następnym. Zmarła przed 1688 r. ${ }^{53}$

Aleksander Sienieński, najstarszy syn Jana Abrahama i Anny Gajowskiej, urodził się około 1630 r. Po raz pierwszy wystapił samodzielnie wkrótce po śmierci ojca, kiedy 28 stycznia $1648 \mathrm{r}$. podpisał w Radomyślu umowę pod zakładem 6000 florenów ze swoja ciotka Krystyna z Gajowa Myszkowska. Roborował tę intercyzę w grodzie krakowskim w 1649 r. Przy tej okazji otrzymał od kasztelanowej oświęcimskiej skwitowanie $z$ ustalonej $\mathrm{w}$ intercyzie kwoty. W 1653 r. na popisie żołnierza łanowego województwa lubelskiego trzej bracia Sienieńscy z Radomyśla wystawili dwa konie. W 1654 r. Aleksander pozywał łowczego koronnego Mikołaja Gniewosza o nasłanie sług i poddanych na Radomyśl i Nowiny. W styczniu $1655 \mathrm{r}$. wraz $\mathrm{z}$ bratem Abrahamem oraz w imieniu małoletniego brata Jana zawarł w Krakowie umowę ze szwagrami Janem Piotraszowskim i Aleksandrem Zebrzydowskim. Sienieńscy zobowiązali się wówczas wypłacić na początku roku 1656 po 5000 florenów posagu obu swoim zamężnym już od jakiegoś czasu siostrom. Trzej bracia Sienieńscy odziedziczyli po ojcu miasteczko Radomyśl oraz wsie Nowiny, Glinnik, Skowierzyn i Rzeczycę.

52 Por. APL, LGR, nr 59, k. 416-417; nr 100, k. 656v-661v, 1656v-1657v; nr 101, k. 621-622v; nr 102, k. 886-888; nr 127, k. 1264-1267; K. Estreicher, op. cit., t. XXI, s. 77; ANK, CCI, nr 248, s. 1308-1311.

${ }^{53}$ Por. ANK, CCI, nr 227, s. 282-285; APL, LGR, nr 95, k. 44v-45v; nr 96, k. 1079v-1080v; nr 100, k. 129-130, 648-648v, 656v-661v; nr 101, k. 621-622; nr 113, k. 532-533; B.H. Łuszczyńs ki, op. cit., t. VII, s. 262-263 (tu wspomniani mężowie Krystyny i Marianny). 
Początkowo wspólnie gospodarowali w tych dobrach. Później dokonali podziału w ten sposób, że Aleksander i Abraham objęli Radomyśl, Nowiny i Glinnik, a Jan Skowierzyn i Rzeczycę. Co ciekawe, ze względu na konieczność wyrównania wartości działów najmłodszy z Sienieńskich zobowiązał się dopłacić braciom 1500 florenów ${ }^{54}$. Od razu musimy też zaznaczyć, że synowie Jana Abrahama nie byli rzadnymi gospodarzami. Bez przerwy wydzierżawiali lub też zastawiali swoje dobra. Prowadzili też nieustające spory natury majątkowej z sąsiadami, dzierżawcami i zastawnikami, jak również $z$ instytucjami Kościoła katolickiego. Mimo przeprowadzenia formalnego działu dóbr po ojcu, w konfliktach natury prawnej bracia występowali najczęściej razem. Warto w tym miejscu odnotować również, że przed 1675 r. Aleksander Sienieński został księdzem. Od tego roku występuje on bowiem w źródłach $z$ tytułem kanonika kamienieckiego.

Losy Aleksandra ściśle splatały się z losami jego młodszych braci. Można je prześledzić na podstawie kolejnych wpisów w księgach grodzkich lubelskich. W 1659 r. Aleksander, Abraham i Jan pozywali Aleksandra Grodzkiego z Rzeczycy Okragłej i Woli Rzeczyckiej o to, że nie płaci czynszu od kwoty 1200 florenów ulokowanej na tych wsiach przez Jana Abrahama Sienieńskiego z przeznaczeniem na utrzymanie kapeli w kościele w Radomyślu. W 1665 r. trzej bracia Sienieńscy zastawili na trzy lata za 2200 florenów Glinnik i część gruntów w Nowinach Krzysztofowi Szeliskiemu i dali mu intromisję w te dobra. Musieli jednak nie dotrzymać warunków intercyzy, gdyż w roku 1671 Szeliski pozwał ich o zwrot należnych mu jakoby 5000 florenów. Aleksander, Abraham i Jan Sienieńscy, ich trzy siostry oraz aktualni dzierżawcy lub zastawnicy dóbr należących niegdyś do ich ojca w latach 1668-1678 kilkakrotnie pozywani byli przez konwent augustianów z Radomyśla o zaległe czynsze od kwot legowanych niegdyś na rzecz klasztoru przez ich stryjecznego dziadka Abrahama i ojca Jana Abrahama. W 1676 r. prezbiter sandomierski pozywał Sienieńskich o zaległe czynsze od kwoty 2000 florenów zapisane przez przodków braci Sienieńskich szpitalowi św. Hieronima w Sandomierzu. Z pretensjami

${ }^{54}$ Por. ANK, CCI, nr 268, s. 1308-1311; nr 277, s. 282-285; APL, LGR, nr 81, k. 1122v; nr 82, k. 145-147; nr 102, k. 835-837; Archiwum Państwowe w Rzeszowie, Archiwum Lubomirskich, sygn. 16, s. 1-3 (tu umowa Sienieńskich z Piotraszowskim i Zebrzydowskim. $Z$ jej tekstu wynika, że oba małżeństwa siostrzenic zaaranżowała Krystyna z Gajowskich Myszkowska, kasztelanowa oświęcimska). 
wobec wszystkich trzech synów Jana Abrahama występowały też w latach 1671-1688 dzieci w Wawrzyńca Kosa i Anny z Sienna, Jan Kazimierz i Teresa $1^{\circ} \mathrm{v}$. Janowa Bębnowska $2^{\circ} \mathrm{v}$. Stanisławowa Głębocka. Domagali się oni zwrotu pożyczki w wysokości 4000 florenów udzielonej niegdyś przez Wawrzyńca Kosa Janowi Abrahamowi oraz 7000 florenów posagu ich babki, Katarzyny z Bobrku Ligęzianki oprawionego niegdyś przez Marcina Sienieńskiego na wszystkich jego dobrach ${ }^{55}$.

W 1669 r. Aleksander Sienieński (wraz z bratem Janem) skarżył Szymona i Mikołaja Słoniowskich o napaść na drodze. W 1672 i 1673 r. wspólnie $z$ młodszymi braćmi toczył spory $z$ Hieronimem i Stanisławem Roszkowskimi, którzy najpierw dzierżawili, a następnie wzięli w zastaw część dóbr należących do Sienieńskich (trzymali m.in. Radomyśl, Nowiny i Skowierzyn). W 1675 r. Aleksander, już jako kanonik kamieniecki, uzyskał od biskupa krakowskiego Andrzeja Trzebickiego zgodę na to, aby mógł użytkować swoją dziedziczna wieś Glinnik na tych samych zasadach, jak gdyby stanowiła ona uposażenie jego kanonii. W 1677 r. wszyscy trzej bracia występowali $z$ różnego rodzaju pretensjami wobec Andrzeja Aleksandra Kuczkowskiego, posesora dóbr sąsiadujących $z$ należącą do Jana Rzeczycą. Sienieńscy kontynuowali też spory z Roszkowskimi, którzy na mocy dekretu Trybunału Koronnego otrzymali zgodę na przeprowadzenie egzekucji w Radomyślu i w Nowinach w celu odzyskania przysadzonej im kwoty 75 tys. florenów. W tym samym roku Aleksander, Abraham i Jan wystąpili też jako strona $\mathrm{w}$ sporze $\mathrm{z}$ kanonikiem sandomierskim Stanisławem Umińskim. W latach 1678-1679 Aleksander Sienieński kontynuował spór o Rzeczycę z Andrzejem Aleksandrem Kuczkowskim. Ten sam Kuczkowski pozywał też Aleksandra i Abrahama Sienieńskich w 1681 r. W tym samym roku Aleksander, oprócz kanonii kamienieckiej, trzymał również probostwo w Czułczycach w ziemi chełmskiej i jako tamtejszy pleban pozywał o dziesięciny Stanisława Bielskiego, właściciela wsi Krobinosza ${ }^{56}$.

55 Por. APL, LGR, nr 84, k. 416-417; nr 93, k. 732v-736; nr 94, k. 479-479v; nr 96, k. 1079v-108v; nr 97, k. 723-724, 980v-982v, 995-997v; nr 98, k. 281281v; nr 99, k. 233v-235, 606-606v; nr 100, k. 129-130, 648-649v, 656v-661v; nr 101, k. 621-622v; nr 102, k. 886-888; nr 111, k. 1324-1325; nr 113, k. 116116v, 532-533, 539v-540; nr 114, k. 564v-565.

${ }_{56}$ Por. ANK, CCI, nr 302, s. 918-919; APL, LGR, nr 95, k. 733-734, 883v-885; nr 98, k. 704-706; nr 99, k. 37v-39v, 585-586; nr 101, k. 34-37, 376-379v, 
W 1684 r. zmarł bezpotomnie najmłodszy z braci Sienieńskich Jan. Aleksander oraz Abraham, spadkobiercy zmarłego, wystapili wówczas wobec Jana Roszkowskiego $z$ pretensjami do należącej niegdyś do Jana wsi Skowierzyn, która Roszkowski trzymał modo obligatorio (podobnie zreszta jak Radomyśl, Nowiny i Ocierchów). W 1688 r. kanonik kamieniecki procesował się o poddanego $z$ Janem Skórka, dziedzicem części wsi Wilczopole. Został także pozwany (wraz z bratem Abrahamem) przez Jana Aleksandra Gajowskiego o sumy, jakie Sienieńscy winni byli jakoby nieżyjącej już od dawna Krystynie z Gajowa Myszkowskiej, kasztelanowej oświęcimskiej. Przy tej okazji okazało się, że wszystkie dobra należące do Aleksandra i Abrahama, a więc miasto Radomyśl oraz wsie Glinnik, Nowiny, Skowierzyn i Rzeczyca znajdowały się w tym czasie w rękach posesorów zastawnych: braci Sebastiana, Stanisława i Jana Roszkowskich, Jana Samuela Kochanowskiego, Piotra Hadziewicza i Andrzeja Aleksandra Kuczkowskiego. Na pozew Gajowskiego obaj bracia odpowiedzieli pozwem pod jego adresem, powołując się na własne prawa do spadku po ciotce Myszkowskiej. W tym samym roku kanonik kamieniecki procesował się jeszcze Franciszkiem i Marianną Wilczopolskimi. Rok później został odnotowany w źródle jako proboszcz w lubelskich Abramowicach. W 1690 r. Aleksander i Abraham Sienieńscy zostali pozywani przez Jana Roszkowskiego ze Skowierzyna i Andrzeja Aleksandra Kuczkowskiego z Rzeczycy (zatem wiosek stanowiących niegdyś własność ich brata Jana). Spadkobiercy kupca lubelskiego Kazimierza Poznańczyka wystapili też wobec nich z żądaniem zwrotu 3000 florenów pożyczonych przez nieżyjącego już od sześciu lat Jana Sienieńskiego. Jesienią 1690 r. zmarł również kanonik kamieniecki. Nie żył już na pewno 2 listopada tego roku, gdy Gajowscy ponownie zgłosili pretensje do sum należnych im po Krystynie z Gajowa Myszkowskiej (chodziło o umowy zawarte przez Aleksandra $z$ kasztelanową oświęcimska w roku 1648 i 1654, pierwsza pod zakładem 6000, a druga 10 tys. (lorenów $)^{57}$. Kanonik kamieniecki Aleksander Sienieński, mimo że dość późno zdecydował się zostać księdzem, nigdy nie był żonaty. $\mathrm{Z}$ oczywistych powodów nie pozostawił po sobie potomstwa.

450-456v, 1230v-1231; nr 102, k. 671-671v, 815v-816v, 971-971v; nr 103, cz. 2, k. 767v-768v; nr 105, k. 295v-296, 1747-1747v.

57 Por. APL, LGR, nr 108, k. 767-769v; nr 113, k. 72v-73, 77v-78v, 297-298, 299v-300v, 1009-1010; nr 122, k. 124v; nr 127, k. 432v-433v, 1244-1246; nr 129, k. $112-113$. 
Abraham, raz tylko wspomniany jako Abraham Kazimierz, był średnim synem Jana Abrahama i Anny Gajowskiej. Zważywszy na to, że w styczniu 1655 r. był już pełnoletni, możemy przypuszczać, że urodził się on około 1633 r. Jak już wspomniano, uczestniczył w większości spraw, w których strona był jego starszy brat Aleksander. O Abrahamie wiemy również, że wraz z ówczesnym posesorem swojej części Radomyśla, chorą̇ym grabowieckim Janem Kazimierzem Czarnowskim pozywal przeora konwentu augustianów w tym mieście. W roku 1680 ze swoją żoną, Dorotą Roszkowska, spadkobiercami Czarnowskiego i teściem Janem Roszkowskim został $z$ kolei pozwany przez młodszego brata Jana Sienieńskiego i jego żonę, Annę z Rzeczyckich o 6000 florenów. Abraham, jako dziedzic Radomyśla i Nowin, był także strona w procesach, które prowadził jego teść, Jan Roszkowski, który przynajmniej od roku 1680 trzymał w zastawie obie te miejscowości. W 1688 r. Abraham Sienieński zawarł jakąś umowę $z$ Hieronimem Roszkowskim pod zakładem 64500 florenów. Pociagnęło to za soba protesty ze strony Kazimierza Łęskiego, któremu Sienieński wcześniej obiecał oddanie w zastaw wszystkich swoich dóbr. W tym samym roku zmarł teść Abrahama, Jan Roszkowski, a jego synowie Sebastian, Stanisław i Jan dokonali podziału dóbr po ojcu. $Z$ aktu podziałowego wynika, że starszy Jan Roszkowski miał ulokowaną na Radomyślu i Nowinach sumę zastawu w wysokości 29264 floreny. Był też właścicielem 3/4 wsi Skowierzyn, która to część kupił od Jana Sienieńskiego za 30880 florenów. Jeszcze w tym samym, 1688 r. szwagrowie Abrahama odstąpili zastaw na Radomyślu cześnikowi łukowskiemu Janowi Samuelowi Kochanowskiemu, który uzyskawszy od Roszkowskich zgodę na intromisję, obją to miasteczko (wraz z Nowinami i Glinnikiem) w realne posiadanie ${ }^{58}$.

W 1688 r. Abraham Sienieński z żoną Dorota $z$ Roszkowskich wziął za 10 tys. florenów w zastaw część Grabówki, wioski należącej wówczas do Hieronima i Katarzyny z Czermińskich Roszkowskich. Od tej pory, uzyskawszy intromisję w te dobra, występował w aktach lubelskich jako zastawny posesor Grabówki. W tym samym roku był pozywany przez Teresę $z$ Kosów $1^{\circ} \mathrm{v}$. Bębnowską $2^{\circ} \mathrm{v}$. Głębocką o stary dług zaciagnięty przez Jana Abrahama Sienieńskiego u Wawrzyńca Kosa. W 1689 r. Sienieński toczył spór z Janem Samuelem Kochanowskim, na rzecz którego definitywnie

58 Por. APL, LGR, nr 102, k. 988v; nr 104, k. 993v-994; nr 108, k. 357-357v; nr 113, k. 198v-200, 262v-263v, 339v-341, 395v-396v, 403-407v, 530. 
zrezygnował z własności Radomyśla i Nowin. Chodziło w tym przypadku o kwotę 6000 florenów, która stanowiła ostatnia ratę umówionej wcześniej sumy, za którą Abraham sprzedał cześnikowi łukowskiemu wspomniane dobra ${ }^{59}$. Użytkowanie przez Abrahama i Dorotę z Roszków Sienieńskich części Grabówki uwikłało małżonków w spory nie tylko $z$ jej właścicielami, czyli Hieronimem i Katarzyna z Czermina Roszkowskimi, lecz także $z$ ich krewnymi, Franciszkiem i Krystyna z Oszczepalskich Sobieszczańskimi, którzy także zgłaszali pretensje do tych dóbr. W sierpniu 1694 r. Abraham i Dorota Sienieńscy pozwali wreszcie Hieronima i Katarzynę Roszkowskich o niewykupienie w umówionym terminie z zastawu części Grabówki. Zwrotu Dorocie i jej mężowi 10 tys. florenów domagali się od Hieronima i jego żony także bracia Sienieńskiej, Sebastian i Jan Roszkowscy. W uzupełnieniu dodajmy, że w 1692 r. Abraham pozywał cześnika łukowskiego Jana Samuela Kochanowskiego o 3000 florenów stanowiących ostatnią część zapłaty za dobra radomyskie, a w grudniu $1694 \mathrm{r}$. toczył jakiś spór z Janem Bogusławem Pszonka. W 1695 r. Abraham i Dorota Sienieńscy odzyskali wreszcie pieniądze, jakie wyłożyli na zastaw części Grabówki. Wzięli bowiem wówczas w zastawne posiadanie za 10 tys. florenów Wolicę Głuską, wieś należąca do podczaszego lubelskiego Tomasza Głuskiego. Dnia 28 maja 1696 r. Abraham Sienieński został pozwany przez kasztelana kamienieckiego Mikołaja Żaboklickiego w związku $z$ procesem, jaki ten ostatni toczył z Pawłem Hadziewiczem. Pozew przeciwko Sienieńskiemu złożono we wsi Świdno w parafii Chodel. Na tej podstawie możemy wnioskować, że tam wówczas przebywał. Dalsze losy Abrahama Sienieńskiego nie są znane. Nie wiemy także, czy miał on jakieś dzieci $z$ małżeństwa $z$ Dorotą Roszkowską h. Rola. Najpewniej zmarł jednak bezpotomnie.

Jan, który od końca lat sześćdziesiątych XVII w. występował w źródłach niemal zawsze jako Jan Mikołaj, był najmłodszym synem Jana Abrahama i Anny z Gajowskich. W styczniu 1655 r. był jeszcze niepełnoletni, skąd możemy wnosić, że urodził się po 1635 r. Na podstawie dwóch zapisów źródłowych można odnieść wrażenie, że czuł się pokrzywdzony przez braci przy podziale

${ }^{59}$ Por. APL, LGR, nr 104, k. 1142v; nr 114, k. 111, 564v-565; nr 120, k. 1207v1208; nr 139, k. 507v, 660v-661v, 747-747v; nr 140, k. 155-155v, 175-175v; nr 148, k. 80v, 167v, 278v; nr 153, k. 396v, 547-547v, 709-709v, 735; nr 158, k. 298-298v; nr 164, k. 441v-442. 
majątku po rodzicach. W 1666 r. pozywał Aleksandra i Abrahama o 3600 florenów. Podobne sformułowanie pojawia się też $\mathrm{w}$ zapisce pochodzacej $\mathrm{z}$ roku 1673. Od początku samodzielnego gospodarowania w Skowierzynie i Rzeczycy miał sporo problemów natury finansowej. Dnia 2 sierpnia 1667 r. zawarł w Sandomierzu układ z kupcem lubelskim Krzysztofem Sorgenfreyem, na mocy którego, w celu spłacenia starych długów, wynoszących wówczas 4326 florenów, dał kontrahentowi, który wyłożył sumę należną wierzycielom Sienieńskiego, intromisję do Skowierzyna. W umowie zaznaczono ponadto, że Sorgenfrey będzie trzymał tę wieś od 14 lutego 1668 r. aż do czasu odzyskania całej należności. Po ustapieniu ze Skowierzyna sygnatariusza tej umowy Jan Mikołaj zastawił tę wioskę Hieronimowi i Stanisławowi Roszkowskim, od których $z$ kolei przeją zastaw na Skowierzynie Jan Roszkowski. W 1677 r. Sienieński był już żonaty z Anną Rzeczycką. W sporze z Kuczkowskimi, którzy dokonali wówczas zajazdu Rzeczycy Małej, odnotowano bowiem, że Jan Mikołaj i jego żona maja na tej wsi ulokowaną kwotę 24 tys. florenów. Z Roszkowskimi prowadził Sienieński szereg różnych sporów. Pozywali go oni m.in. o nieoddanie pożyczonych na skrypt 4000 florenów. Ze skarg zastawników na Skowierzynie wynika, że Jan Mikołaj przy podziale dóbr z braćmi złożył zobowiązanie, że będzie płacił na rzecz klasztoru augustianów w Radomyślu czynsz od kwoty 2500 florenów ulokowanej na Skowierzynie. Ponieważ jednak latami tego nie robił, augustianie zażądali wreszcie spłacenia zaległości przez aktualnych posesorów tej wioski. Ci z kolei w latach 1677-1678 pozywali o uregulowanie tej należności dziedzica, czyli Jana Mikołaja. Spory natury majątkowej prowadził też Sienieński z zastawnym posesorem Rzeczycy Małej, Andrzejem Aleksandrem Kuczkowskim (w 1678 r.) oraz ze Stanisławem Roszkowskim (w 1681 r.). Jak już wspomniano, najpewniej przed 1683 r. Jan Mikołaj Sienieński sprzedał 3/4 Skowierzyna Janowi Roszkowskiemu, który trzymał też w zastawie pozostała część tej wsi. Nie był też w stanie wykupić $z$ zastawu od Kuczkowskich Rzeczycy Małej. Jan Mikołaj Sienieński zmarł przed 17 sierpnia 1684 r. Z małżeństwa $z$ Anną Rzeczycką h. Janina nie pozostawił potomstwa ${ }^{60}$.

60 Por. APL, LGR, nr 92, k. 17-17v; nr 93, k. 1382-1385; nr 99, k. 29-30, 228v-230v; nr 101, k. 452-456v, 1530-1531; nr 102, k. 210v, 427v-429, 566v567v, 726v, 835-837; nr 105, k. 78v-79v; nr 107, k. 701; nr 108, k. 767-769v. 
Jan Sienieński był najmłodszym synem, a jednocześnie jedynym dzieckiem kasztelanica małogoskiego Wiktoryna Sienieńskiego $z$ jego drugiego małżeństwa $z$ Jadwiga Leską h. Janina. Niestety, niewiele o nim wiadomo. W 1571 r. w dziale dóbr ze starszymi braćmi wziął dużą wieś Chroślinę. W pierwszej połowie 1572 r. otrzymał jakiś zapis od własnej matki. $Z$ pewnością założył też rodzinę. Nie znamy jednak nazwiska jego małżonki. Stosunkowo też szybko Jan Sienieński pożegnał się $z$ tym światem. Zmarł na początku lat dziewięćdziesiątych XVI w. Nie żył już na pewno 16 marca 1592 r., gdy dokonano ostatniego wpisu do cytowanej poniżej lubelskiej księgi zobowiąań. Pozostawił po sobie jedynego syna-Zbigniewa ${ }^{61}$.

Zbigniew, syn Jana $z$ Chrośliny i jego nieznanej $z$ imienia i nazwiska żony, był $z$ pewnością najwybitniejszym przedstawicielem lubelskiej gałęzi domu Sienieńskich. Jako jedyny spośród nich piastował godność senatorską. Doczekał się również, podobnie jak jego pradziadek, kasztelan małogoski Wiktoryn Sienieński, biogramu w Polskim słowniku biograficznym ${ }^{62}$. Niestety, autor tego tekstu - Henryk Gmiterek popełnił bardzo dużo różnego rodzaju błędów, które postaram się w tym miejscu sprostować. Warto również uzupełnić biografię Zbigniewa o informacje pominięte w jego biogramie. Zacznijmy może od stwierdzenia, że nieprawdziwa jest informacja, jakoby Zbigniew Sienieński był synem kasztelana halickiego Jana (zm. 1580) i Zofii Paniowskiej h. Godziemba. Jego filiacja jest bowiem jednoznacznie potwierdzona źródłowo. W zapisach pochodzacych $z$ lat dziewięćdziesiątych XVI w. występuje on bowiem nie tylko jako dziedzic Chrośliny i syn nieżyjącego już Jana, lecz także jako bratanek (filiastro) Jakuba Sienieńskiego z Mazanowa i Wałowic. Z tym ostatnim procesował się w 1596 r. o należną mu sumę 1200 florenów $^{63}$.

${ }^{61}$ Por. APL, LZW, nr 84, k. 26-26v; LGR, nr 55, k. 539-539v; LZZ, nr 102, k. 836-836v; Z. Anu sik, Krag rodzinny..., s. 250.

${ }^{62}$ Por. H. G miterek, Sienieński Zbigniew, [w:] PSB, t. XXXVII, s. 193-194.

${ }^{63}$ Por. ibidem, s. 193; APL, LZZ, nr 102, k. 836-836v (tu Jakub Sienieński potwierdza, że winien jest 3000 florenów swojemu bratankowi Zbigniewowi z Chrośliny); LGR, nr 30, s. 2240-2241, 2311, 2376-2377 (tu Zbigniew, syn nieżyjącego Jana, dziedzic Chrośliny, żąda zwrotu 1200 florenów od swojego stryja, Jakuba z Mazanowa i Wałowic); Z. Anusik, Krag rodzinny..., s. 250. Dodajmy w tym miejscu, że sprostowania wymagaja również informacje zawarte w biogramie kasztelana halickiego Jana Sienieńskiego. Wbrew temu, co podaje autorka, pozostawił on po sobie nie pięciu, ale tylko trzech synów. Synem Jana nie był na pewno Zbigniew, a prawdopodobnie również Jan. Po śmierci kasztelana halickiego wdowa po nim wszelkie czynności prawne podejmowała bowiem w imieniu własnym 
Poważnym błędem H. Gmiterka jest pominięcie w napisanym przez niego biogramie informacji o pierwszym małżeństwie Zbigniewa Sienieńskiego. Tymczasem od dawna wiadomo, że przed 1605 r. ożenił się on $z$ Anną Leńkówną h. Rawicz, córka Macieja Leńka $z$ Rokitnicy (ok. 1545-1609), kasztelana derpskiego, i Teodory Sapieżanki h. Lis, rodzonej siostry Lwa Sapiehy (1557-1633), kanclerza wielkiego litewskiego, a następnie wojewody wileńskiego i hetmana wielkiego litewskiego. Znaczenia tej koligacji dla dalszych dziejów życia i kariery Sienieńskiego z pewnością nie można nie doceniać. Już w 1605 r. kasztelan derpski przekazał za zgoda Zygmunta III córce i zięciowi swoje (bliżej niezidentyfikowane) dobra w Inflantach. Po śmierci Macieja Leńka Zbigniew i Anna Sienieńscy weszli $z$ kolei w posiadanie Rokitnicy i Bartkówki w województwie rawskim. Dnia 17 maja 1614 r. oboje małżonkowie zostali odnotowani w księgach grodzkich lubelskich, gdy wystąpili z pozwem przeciwko Mikołajowi i Teofilowi Mierzejowskim, od których domagali się zwrotu dóbr w powiecie nowogródzkim w Inflantach, których wartość oszacowali na 100 tys. florenów ${ }^{64}$.

Dnia 1 sierpnia 1618 r. Zbigniew Sienieński otrzymał nominacje na urząd chorążego lubelskiego. Posłował też ze swojego województwa na pięć sejmów, w 1616, 1621, 1624, 1627 i 1629 r. (sejm nadzwyczajny). Dnia 1 maja 1630 r. został kasztelanem lubelskim. Pod koniec 1620 r. ożenił się z Krystyną Uhrowiecką h. Suchekomnaty, wdowa po podkomorzym mielnickim Kasprze Dembińskim. Druga żona Zbigniewa była córka starosty chełmskiego Mikołaja Uhrowieckiego. Mężowi wniosła wieś Sielec z zamkiem w ziemi chełmskiej, która 12 marca 1622 r. wykupiła (za 6000 florenów) $z$ zastawu od Jerzego i Doroty Błędowskich. Po bezpotomnej śmierci brata Marcina, który zmarł w 1621 lub też na początku 1622 r., będąc jego główną spadkobierczynią, Krystyna Sienieńska zawarła

oraz synów: Łukasza, Samuela i Mikołaja. Por. I. Kaniews ka, Sienieński Jan, [w:] PSB, t. XXXVII, s. 188-189; ANK, Grodzkie bieckie, Inskrypcje i relacje, nr 18, s. 564, 613-614, 661, 673, 749 .

${ }^{64}$ Por. W. Majew ski, Leniek Maciej z Rokitnicy, [w:] PSB, t. XVII, WrocławWarszawa-Kraków 1972, s. 52-53; Z. Anu sik, Garwascy herbu Grzymała w XVXVII wieku. Przyczynek do dziejów i genealogii rodu, „Przegląd Nauk Historycznych” 2015, R. XIV, nr 2, s. 72-73; APL, LGR, nr 44, k. 248; nr 57, k. 576v-578v (tu Zbigniew Sienieński nazwany dziedzicem na Rokitnicy i Bartkówce). Dodajmy w tym miejscu, że Sienieńscy nie otrzymali w spadku po Macieju Leńku jego dziedzicznej wsi Żdżary, gdyż kasztelan derpski przekazał tę wieś na rzecz Kościoła jako uposażenie miejscowej parafii. 
kilka transakcji majątkowych. Przede wszystkim przed 6 kwietnia 1622 r. z siostrą Zofia (zakonnica) potwierdziła dokonaną przez brata donację (właściwie sprzedaż) dużej włości radziechowskiej (Radziechów z 9 innymi wsiami) w ziemi chełmskiej na rzecz chorążego koronnego Stefana Snopkowskiego. Zobowiązała się też zaspokoić pretensje wierzycieli Marcina Uhrowieckiego: Stanisława Wereszczyńskiego, Aleksandra Krzywczyckiego i podkomorzego chełmskiego Jana Skaszewskiego. Przy tej samej okazji Zbigniew Sienieński skwitował żonę z pożyczonych jej wcześniej 1470 florenów i otrzymał od Snopkowskiego zapis na kwotę 3000 florenów. Krystyna Sienieńska nie pogodziła się natomiast $z$ przejęciem przez miecznika wołyńskiego Jana Bądzyńskiego wszystkich innych dóbr po Marcinie Uhrowieckim w ziemi chełmskiej. Twierdziła, że majątki te zostały jej zapisane przez brata, a bezprawne ich użytkowanie przez Bądzyńskiego naraziło ja na straty szacowane na 200 tys. grzywien. Przedmiotem sporu były m.in. wsie Dzdzane (dziś Żdżanne), Wierzchowiny, Uher, Weremowice i Dypułtycze Ruskie. W pozwach Sienieńskiej przeciwko miecznikowi wołyńskiemu pojawiają się również nazwy kilku innych wsi, których nie udało się zidentyfikować. Jak się jednak wydaje, zabiegi Krystyny o odzyskanie dawnego dziedzictwa Uhrowieckich nie przyniosły żadnych rezultatów. W sporządzonym 1 czerwca 1629 r., na potrzeby wybieranego wówczas poboru, spisie miast i wsi ziemi chełmskiej wszystkie sporne wioski odnotowano bowiem jako własność Jana Bądzyńskiego ${ }^{65}$.

Istotna wartość materialna miały dla Sienieńskich zapisy poczynione na rzecz Krystyny przez jej pierwszego męża. Jeden $z$ tych zapisów Kacper Dembiński zabezpieczył na wsiach Jabłoń, Kolano, Pasieki i Kudry w ziemi mielnickiej. Chorążyna lubelska starała się o uzyskanie intromisji do tych dóbr w 1624 r. Jej zabiegi zakończyły się jednak niepowodzeniem, gdyż wspomniane wioski stanowiły część dużego klucza horodyskiego, który wniosła Dembińskiemu jego pierwsza żona, Maryna Kopciówna. W ostatecznym rozrachunku sporne wsie przyznano więc spadkobiercom trzech córek podkomorzego mielnickiego $z$ jego pierwszego małżeństwa. Inaczej wyglądała sprawa $z$ zapisem 20 tys. florenów, który Kasper

65 Por. H. Gmiterek, op. cit., s. 194; AGAD, MK 159, k. 241-241v; APL, Chełmskie grodzkie, Zapisy [dalej: ChGZ], nr 19, s. 245; nr 20, s. 305-306; nr 21, s. 1565, 1575, 1579; LZWZ, nr 109, k. 365v-369, 376v-379; LGR, nr 57, k. 573-573v; nr 58, k. 568-568v. 
Dembiński zabezpieczył Krystynie na swoich dziedzicznych wsiach w powiecie ksiąskim w województwie krakowskim. $Z$ zachowanych źródeł wynika, że Sienieńska objęła w realne posiadanie, „jako pani oprawna i dożywotnia”, Piotrkowice, Strzeszkowice i część Olbrachcic, a być może również Błonie i Zakrzów. Dobra te najczęściej wydzierżawiała w późniejszym okresie krewnym swojego pierwszego męża. Rejestrowała bowiem w grodzie krakowskim umowy zawierane $z$ Janem (pod zakładem 16 tys. florenów), Andrzejem Samuelem (w sprawie arendy Piotrkowic) oraz Erazmem (pod zakładem 14 tys. florenów) Dembińskimi ${ }^{66}$.

Warto w tym miejscu wspomnieć także o dwóch nieznanych epizodach z życia Zbigniewa Sienieńskiego. Przyjaźnił się on przez długie lata $z$ Aleksandrem Krzywczyckim oraz z Mikołajem Gniewoszem. W 1622 r., po śmierci Krzywczyckiego, chorąży lubelski wraz z Gniewoszem sprawował opiekę nad dziećmi zmarłego przyjaciela. Ich zaangażowanie w sprawy Krzywczyckich ściagnęło na Sienieńskiego niespodziewane kłopoty. Obaj opiekunowie zagwarantowali bowiem własnym majątkiem pożyczkę w wysokości 14 tys. florenów, jakiej udzielił Aleksandrowi kasztelan sochaczewski Konstanty Plichta. Ponieważ zaś wdowa po Aleksandrze, Elżbieta $z$ Gniewoszów (siostra Mikołaja) nie spłaciła długu w terminie, Plichta wystapił $z$ roszczeniami wobec Sienieńskiego i Gniewosza. W 1628 i 1629 r. chorąży lubelski musiał odpierać zakusy kasztelana na przejęcie Chrośliny, do której Plichta uzyskał intromisję na podstawie wyroku sądu grodzkiego w Sochaczewie. Ostatecznie jednak sprawę udało się załatwić polubownie, gdyż Krzywczyccy, $z$ pewnym wsparciem ze strony opiekunów, zaspokoili roszczenia tego wierzyciela. Sprawa druga była dużo poważniejszej natury. Zbigniew Sienieński wziął bowiem udział w intrydze mającej na celu ubezwłasnowolnienie jego dalszego krewnego, przywódcy arian polskich, wojewodzica podolskiego Jakuba Sienieńskiego z Rakowa. Dnia 8 listopada 1627 r. Zygmunt III wystawił dokument, na mocy którego ustanowił chorażego lubelskiego kuratorem osoby i majątku Jakuba. Zgodnie $z$ treścią tego dekretu Jakub Sienieński nie mógł dokonywać jakichkolwiek czynności prawnych, zwłaszcza

66 Por. APL, LGR, nr 54, k. 571-573v; ANK, CCI, nr 226, s. 2085; nr 231, s. 1269-1270, 1274-1276; nr 243, s. 1531-1532; nr 244, s. 865-874. Dodajmy w tym miejscu, że wsie Olbrachcice i Błonie nie zostały odnotowane w Rejestrze poborowym z 1629 r. Musiały to więc być przysiółki Piotrkowic, Strzeszkowic i Zakrzowa. 
zaś transakcji dotyczących jego dóbr nieruchomych i ruchomych bez zgody swojego opiekuna. Rzecz jasna dziedzic Rakowa bez trudu uzyskał skasowanie tej kurateli, jako uzyskanej w złej wierze i na podstawie nieprawdziwych zarzutów, po czym sam wystapił $z$ oskarżeniami wobec Zbigniewa Sienieńskiego oraz generała ziem podolskich Stefana Potockiego i jego żony Marii z Mohyłów, których uważał za inicjatorów tej intrygi. Co więcej, wystąpił też wobec całej trójki $z$ roszczeniami finansowymi za doznane straty, które oszacował na 36 tys. florenów. Podjął też nieudaną próbę intromisji do Chrośliny. Spór obu Sienieńskich ciagnął się aż do śmierci Zbigniewa. Dziedzic Rakowa procesował się bowiem później również $\mathrm{z}$ jego spadkobiercami ${ }^{67}$.

W cytowanym już biogramie Zbigniewa Sienieńskiego opublikowanym w Polskim słowniku biograficznym znalazła się informacja, że był on właścicielem jedynie odziedziczonej po ojcu Chrośliny (25 łanów) oraz kupionej w 1612 r. części wsi Boby (1,5 łanu). Nie jest to prawda. Sienieński był człowiekiem o wiele zamożniejszym. W 1624 r. przejał od Aleksandra Kołaczkowskiego zastaw na wsiach Radlna $z$ folwarkiem oraz Kłokowa (łaccznie 3 łany) w powiecie pilzneńskim, województwie sandomierskim. Na mocy umowy zawartej z dziedzicem tych wiosek, Andrzejem Chrzasstowskim, który dał mu intromisje w te dobra, miał tu ulokowane 10 tys. florenów. Jak już wspomniano, po pierwszej żonie otrzymał w dożywocie wsie Rokitnica i Bartkówka w województwie rawskim. Druga żona wniosła mu wieś Sielec z zamkiem w ziemi chełmskiej. Krystyna $z$ Uhrowieckich Sienieńska użytkowała też na mocy zapisu pierwszego męża wsie Piotrkowice (9,5 łanu), Zakrzów (3 łany) i Strzeszkowice (2,25 łanu) $z$ częścią Olbrachcic w powiecie ksiąskim. Przed $1628 \mathrm{r}$. Sienieński kupił za 30 tys. florenów od swojego stryjecznego bratanka Jana Abrahama miasteczko Prawno (1 łan) z wsiami Mazanów (2 łany) i Wola Lubaszowa (1,5 łanu) w powiecie urzędowskim. W $1629 \mathrm{r}$. dzierżawił też od dalszego krewnego drugiej żony, Jana Uhrowieckiego wsie Uhrowsko, Wola Uhrowiecka, Zabuże i Mszanka

${ }^{67}$ Por. APL, ChGZ, nr 19, s. 498-499 (tu Zbigniew Sienieński jako opiekun dzieci Aleksandra Krzywczyckiego); nr 21, s. 1098 (tu Z. Sienieński kwituje z 3000 florenów, długu zaciagniętego jeszcze przez A. Krzywczyckiego jego córkę Jadwigę i jej męża Aleksandra Szujskiego); LGR, nr 57, k. 576v-578v, 634, 740v-742; nr 58, k. 288v-289, 577-578 (tu Jakub Sienieński pozywa Zbigniewa oraz Potockich); nr 61, k. 92-93 (tu Z. Sienieński oblatuje dekret Zygmunta III z 8 XI 1627 r. w sprawie kurateli nad Jakubem $z$ Rakowa). 
w ziemi chełmskiej. Jak więc widzimy, na przełomie 1628 i 1629 r. chorąży lubelski Zbigniew Sienieński był właścicielem 1 miasta, 3 wsi całych i 1 części wsi (łącznie 31 łanów), a na 2 kolejnych wsiach miał dożywocie po pierwszej żonie. Był także posesorem zastawnym 2 wsi (3 łany) oraz dzierżawca 4 osad. Druga żona Sienieńskiego była w tym czasie właścicielka 1 wsi oraz dożywotnią użytkowniczką 3 innych (razem 14,75 łanu). W rękach małżonków Sienieńskich znajdowało się więc wówczas 1 miasteczko oraz 15 wsi całych i 2 części wsi. W dobrach leżących w powiatach urzędowskim, ksiąskim i pilzneńskim użytkowali oni 48,75 łanu chłopskiego ${ }^{68}$.

W 1629 r. Krystyna $z$ Uhrowieckich Sienieńska sprzedała swoja dziedziczną wieś Sielec z zamkiem Mikołajowi Daniłowiczowi, najmłodszemu synowi nieżyjącego już podskarbiego wielkiego koronnego Mikołaja. Potrzebowała bowiem pieniędzy na sfinalizowanie innej dużej transakcji. W tym samym roku kupiła bowiem od Hieronima, Mikołaja i Zbigniewa Ossolińskich (w imieniu młodszych braci występował Hieronim), synów nieżyjącego Prokopa, wszystkie należące do nich dobra w powiecie urzędowskim. Zapłaciła za nie w sumie 80 tys. florenów, przy czym połowę należności uiściła od razu, a $z$ drugiej części została skwitowana dopiero w styczniu 1637 r. Niemniej jednak już w lipcu 1629 r. uzyskała intromisję do nabytych od Ossolinskich dóbr. Krystyna $z$ Uhrowska Sienieńska stała się tym samym właścicielka wsi Rybitwy $z$ folwarkiem (7 łanów), Nieszowa $z$ folwarkiem (3,5 łanu), Kolczyn $z$ folwarkiem (12,5 łanu), Bór seu Wola Borowa $z$ folwarkiem (13 łanów), Kaliszany z folwarkiem (6,5 łanu), Ostrów seu Grodzisko (wieś zagrodnicza), Basonia (9 łanów), Łopoczno (5 łanów) i Wola Judaszowa (5 łanów). Majątek małżonków Sienieńskich powiększył się więc o 9 wsi i 61,5 łanu chłopskiego. W 1630 r. własnościa Zbigniewa i Krystyny było więc 1 miasto, 12 wsi całych i 1 część wsi w powiecie urzędowskim (razem 92,5 łanu). Ponadto Zbigniew Sienieński trzymał dożywotnio 2 wsie w województwie rawskim, a jego żona na tych samych zasadach 4 wsie całe i 1 część wsi w województwie

${ }^{68}$ Por. H. Gmiterek, op. cit., s. 194; ANK, CCI, nr 220, s. 976-989; Z. Anusik, Struktura własności..., s. 98 (tu jednak jako właściciel wsi Radlna i Kłokowa wymieniony został Mikołaj Kazimierski); APL, LGR, nr 57, k. 576v-578v; nr 59, k. 694-695; Rejestr krakowski 1629, s. 127; Rejestr lubelski 1626, s. 92, 97-99; APL, ChGZ, nr 21, s. 1501. 
krakowskim (razem 14,75 łanu). Nie była to oczywiście fortuna magnacka. Niemniej jednak, dysponujac majątkiem obejmujacym 1 miasto, 18 wsi całych i 2 części wsi, w których odnotowano ponad 107 łanów chłopskich, Sienieńscy $z$ pewnością należeli do grona zamożnej szlachty ${ }^{69}$.

Dnia 1 maja 1630 r. Zbigniew Sienieński otrzymał kasztelanię lubelską. W styczniu 1633 r. znalazł się w grupie kilku senatorów, którzy towarzyszyli zwłokom króla Zygmunta III i królowej Konstancji w drodze $z$ Warszawy do Krakowa. Wzią udział w uroczystościach pogrzebowych i w sejmie koronacyjnym Władysława IV. Przebywając w Krakowie, zawarł z żona jakąś umowę z kasztelanem bieckim Andrzejem Samuelem, sędzia ziemskim krakowskim Stanisławem i Franciszkiem Dembińskimi pod bardzo wysokim zakładem 100 tys. florenów. Dnia 5 kwietnia 1633 r. skwitował Mikołaja Daniłowicza z 57 tys. florenów przyznanych mu wyrokiem Trybunału Koronnego. Zmarł przed 11 czerwca 1633 r. i pochowany został w kościele bernardynów w Lublinie. Henryk Gmiterek podaje (co jest zgodne ze stanem faktycznym), że $z$ małżeństwa z Krystyna Uhrowiecką kasztelan lubelski pozostawił czterech synów i dwie córki ${ }^{70}$. Pominą jednak informację, że $z$ małżeństwa $z$ Anną Leńkówna $z$ Rokitnicy Zbigniew Sienieński miał dwóch synów i trzy córki. Dziećmi kasztelana lubelskiego $z$ pierwszego związku byli: Pawel, Jan, Aleksandra, Katarzyna i Krystyna. Uhrowiecka była natomiast matka: Mikołaja, Stanisława, Zbigniewa i Tomasza oraz Anny i Eufrozyny. Warto w tym miejscu zaznaczyć również, że w chwili śmierci ojca wszystkie dzieci urodzone z Leńkówny były już dorosłe. Najstarszy syn Zbigniewa $z$ drugiego małżeństwa - Mikołaj mógł się urodzić najwcześniej w drugiej połowie 1621 r. Miał więc wówczas około 12 lat. Aż do śmierci kasz-

${ }^{69}$ Por. APL, ChGZ, nr 21, s. 353-354 (tu w zapisce z 24 V 1628 r. Krystyna Sienieńska odnotowana jako właścicielka wsi Sielec z zamkiem), s. 1568-1569 (tu Sielec jako własność Mikołaja Daniłowicza); LGR, nr 58, k. 563-563v, 568v569, 571-571v, 596-596v (tu Stanisław Garwaski, kanonik krakowski i pleban w Piotrawinie, pozywa Krystynę Sienieńska o zaległe opłaty na rzecz Kościoła z wsi Kaliszany, których nie uiściła poprzednia właścicielka tych dóbr, Katarzyna $z$ Biereckich Ossolińska); ANK, CCI, nr 231, s. 1270-1274 (tu Hieronim Ossoliński kwituje Krystynę Sienieńską z 40 tys. florenów, a ona zeznaje, że jest mu winna kolejnych 40 tys. florenów); nr 244, s. 874-875 (tu 15 I 1637 r. Hieronim Ossoliński kwituje Krystynę Sienieńską z 40 tys. florenów); Rejestr lubelski 1626, s. 100-101 (tu informacje o wsiach kupionych od Ossolińskich).

${ }^{70}$ Por. AGAD, MK 178, k. 83v-85v; H. Gmiterek, op. cit., s. 194-195; ANK, CCI, nr 237, s. 1627-1628; nr 238, s. 241. 
telanowej lubelskieji w 1639 r. dzieci Krystyny Uhrowieckiej pozostawały zatem pod jej opieka. Matka występowała też w ich imieniu we wszystkich sprawach urzędowych.

Zanim przejdziemy do omówienia losów potomków Zbigniewa Sienieńskiego, odnotujmy te sprawy, w których występowali wszyscy synowie kasztelana lubelskiego oraz wdowa po nim. Już 27 lipca 1633 r. nastapił podział dóbr po Zbigniewie. Paweł i Jan otrzymali wówczas, za zgoda macochy, intromisję do Chrośliny i folwarku Prędków, a Krystyna $z$ Uhrowska Sienieńska, za zgodą swoich pasierbów, w imieniu małoletnich synów objęła w posiadanie Prawno, Mazanów, Wolę Lubaszowa, Krasne (wieś nie występuje w Rejestrze poborowym z 1626 r.) i część w Bobach. Dwaj dorośli synowie kasztelana lubelskiego $z$ wdowa po nim oraz jej małoletnimi synami byli kilkakrotnie (w latach 1633-1635) pozywani przez Jakuba Sienieńskiego $z$ Rakowa, który domagał się od nich zwrotu 20 tys. florenów i bezskutecznie usiłował wejść w posiadanie Chrośliny. O zwrot 8000 florenów pożyczonych przez Zbigniewa pozywali również wszystkich jego spadkobierców w 1636 r. Jadwiga $z$ Gorzkowskich i Mikołaj Lubienieccy. Także w tym przypadku Sienieńscy musieli odpierać zakusy wierzycieli na objęcie w realne posiadanie Chrośliny. Paweł i Jan Sienieńscy oraz kasztelanowa lubelska i wszystkie jej dzieci (obok czterech synów Krystyny wspomniano tu również jej dwie córki) wystapili też wspólnie w sporze o posiadana przez Zbigniewa kamienicę w Lublinie, która przejał ostatecznie Marek Zwiartowski ${ }^{71}$.

Słów kilka warto też poświęcić dalszym losom Krystyny z Uhrowieckich Sienieńskiej. Już w 1633 r. zastawiła ona wszystkie dobra po mężu, które przypadły w spadku jej synom za 45 tys. florenów swojemu dalszemu krewnemu, Jakubowi Uhrowieckiemu. Ten ostatni nie od razu wszedł jednak w ich posiadanie, gdyż jeszcze w 1635 r. pozywał kasztelanowa lubelską o nieprzekazanie mu zastawionych dwa lata wcześniej dóbr. W styczniu $1637 \mathrm{r}$. Krystyna Sienieńska wydała za mąż swoją jedyną córkę z pierwszego małżeństwa, Franciszkę Dembińską, która poślubiła Ludwika Olizara Wołczkiewicza. Dała jej bardzo wysoki posag, wynoszacy 50 tys. florenów. Przy tej okazji roborowała w grodzie krakowskim

${ }^{71}$ Por. APL, LGR, nr 62, k. 860v-861v, 1067-1067v, 1316v-1317v; nr 63, k. 1103-1103v, 1113-1114v (tu spór o kamienicę w Lublinie); nr 64, k. 527-527v (tu informacja, że dzierżawcą Chrośliny był wówczas Krzysztof Wiszowaty), 801802; nr 65, k. 385v-386v. 
kilka transakcji. Zastawiła wówczas Krzysztofowi Wiszowatemu za 50 tys. florenów wsie Nieszowa, Rybitwy, Kolczyn, Bór, Wola Judaszowa i Basonia. Oddała Hieronimowi Ossolińskiemu 40 tys. florenów, które była mu winna za nabyte w 1629 r. dobra. Scedowała na Ludwika Olizara zapis 20 tys. florenów dokonany na jej rzecz na wsiach Piotrkowice, Strzeszkowice, Błonie i Zakrzów przez podkomorzego mielnickiego Kaspra Dembińskiego. Zeznała wreszcie, że jest winna zięciowi 15 tys. florenów. W tym samym czasie Franciszka $z$ Dembian Olizarowa zeznała ustapienie $z$ dóbr ojczystych i macierzystych i skwitowała matkę $z$ wszelkich pretensji, a Ludwik Olizar Wołczkiewicz oprawił jej 50 tys. florenów posagu na swoich dobrach w województwie kijowskim. Dnia 2 czerwca 1639 r. kasztelanowa lubelska spisała w Kaliszanach swój testament. $Z$ jego treści wynika, że spłaciła wszystkie długi mężowskie oraz wykupiła zastawione wcześniej Uhrowieckiemu i Wiszowatemu dobra. Krystyna $z$ Uhrowieckich Sienieńska zmarła zapewne wkrótce po spisaniu testamentu, a więc jeszcze w 1639 r. ${ }^{72}$

Aleksandra była prawdopodobnie najstarszą córka Zbigniewa i Anny Leńkówny z Rokitnicy. Na początku lat dwudziestych XVII w. wyszła za Stanisława Lanckorońskiego h. Zadora (zm. 1657), w przyszłości wojewodę ruskiego i hetmana polnego koronnego. Miała $z$ nim liczne potomstwo: synów Zbigniewa, starostę skalskiego, Jana, kanonika lwowskiego i kamienieckiego, Hieronima, podkomorzego podolskiego, Przecława, kasztelana czechowskiego, Franciszka, Mikołaja i Marcina, oraz córki Joannę, żonę Andrzeja Światopełka Bolestraszyckiego, i Barbarę. Spośród dzieci Aleksandry Mikołaj, Marcin i Barbara zmarli młodo. Ojca nie przeżył również Zbigniew. Nie znamy niestety daty śmierci Aleksandry z Sienna Lanckorońskiej, ale możemy przypuszczać, że również ona nie przeżyła swojego małżonka. Katarzyna była druga córką kasztelana lubelskiego Zbigniewa i Anny Leńkówny z Rokitnicy. Po 1625 r. wyszła za mąż za Piotra Garwaskiego h. Grzymała (zm. p. 1660), starostę rzeczyckiego. Miała $z$ nim synów Krzysztofa i Ludwika oraz córki Annę, żonę Ludwika Komorowskiego, i Ewę Cecylię, która wyszła najpierw za Jana Kazimierza Szczawińskiego h. Prawdzic, a następnie za Franciszka Sokołowskiego. Data śmierci Katarzyny z Sienna Garwaskiej nie jest znana. Zmarła ona

72 Por. APL, LGR, nr 62, k. 1159v-1160; nr 64, k. 547; ANK, CCI, nr 244, s. 738-742, 865-882; APL, LGR, nr 73, k. 522-523 (testament Krystyny z Uhrowieckich Sienieńskiej). 
jednak na pewno po 1649 r. Trzecia, zapewne najmłodszą córką Zbigniewa Sienieńskiego i Anny Leńkówny była Krystyna. Około 1629 r. odbyła ona nowicjat w klasztorze bernardynek w Lublinie (nazwano ją wówczas chorążanka lubelska). W latach 1650-1653 była przełożoną tego klasztoru. Nic więcej o niej nie wiadomo. Anna Sienieńska była starsza $z$ dwóch córek kasztelana lubelskiego Zbigniewa i jego drugiej żony, Krystyny Uhrowieckiej. Również ona została zakonnica w klasztorze brygidek w Lublinie. Nowicjat odbyła w 1636 r., a śluby zakonne złożyła dwa lata później. Została wspomniana w testamencie matki z czerwca 1639 r. W 1659 r. pozywała Jana, Hieronima, Przecława i Franciszka Lanckorońskich o należny klasztorowi czynsz wyderkafowy od 1500 florenów ulokowanych przez jej matkę na wsi Nieszowa. Zmarła w 1684 r. Eufrozyna Sienieńska była młodszą córka Zbigniewa i Krystyny Uhrowieckiej. $Z$ testamentu jej matki wynika, że chciano ją oddać do klasztoru. Gdyby została zakonnica, bracia mieli jej dać posag w wysokości 4000 florenów, a następne 2000 ulokować na wyderkaf na jakichś dobrach. W przypadku jednak, gdyby wyszła za maż, miała otrzymać takie wyposażenie, jak córki kasztelana lubelskiego $z$ jego pierwszego małżeństwa. Eufrozyna Sienieńska została wspomniana tylko raz, w dokumencie pochodzacym $z$ marca $1654 \mathrm{r}$. Była wówczas żoną niewymienionego $z$ imienia Humienieckiego. Nic więcej o niej nie wiadomo ${ }^{73}$.

Paweł (Paweł Maciej) Sienieński był starszym z dwóch synów kasztelana lubelskiego Zbigniewa $z$ jego pierwszego małżeństwa $z$ Anną Leńkówną $z$ Rokitnicy. Wiemy o nim stosunkowo niewiele. W znanych mi źródłach pojawia się on dopiero po śmierci ojca. Można jedynie przypuszczać, że jeszcze za życia kasztelana objął wraz $z$ młodszym bratem Janem dobra macierzyste w województwie rawskim. $Z$ wdowa po Zbigniewie dwaj starsi jego synowie uzgodnili, że obejmą wspólnie Chroślinę, a reszta dóbr ojcowskich w województwie lubelskim przypadnie ich przyrodnim braciom.

${ }^{73}$ Por. K. Niesiecki, op. cit., t. VI, s. 10 (tu o żonie i dzieciach Stanisława Lanckorońskiego); A. Przyboś, Lanckoroński Stanisław, [w:] PSB, t. XVI, Wrocław-Warszawa-Kraków 1971, s. 455 (tu jednak błędna data ślubu Stanisława i Aleksandry Sienieńskiej, a Przecław Lanckoroński nazwany został kasztelanem czernihowskim zamiast czechowskim. Podano też nieprawdziwą informację, że mężem Joanny był Andrzej Światopełk Zawadzki); Z. Anusik, Garwascy herbu Grzymała..., s. 72-73 (tu również źródła i literatura przedmiotu); M. Borkowska, op. cit., s. 292 (tu informacje o Krystynie i Annie Sienieńskich, zakonnicach w klasztorze bernardynek w Lublinie); APL, LGR, nr 73, k. 522-523 (testament Krystyny z Uhrowieckich Sienieńskiej); nr 85, k. 486v-488v; nr 104, k. 1445v-1448. 
W rzeczywistości jednak wspomniana wioska przeszła w posiadanie Pawła, któremu ojciec w 1632 r. zapisał 50 tys. florenów. Uzgodniono też wówczas, że po śmierci Zbigniewa Paweł będzie trzymał Chroślinę w tej sumie modo obligatorio. W 1635 r. odnotowano spór Pawła Sienieńskiego $z$ dzierżawca tej wioski Pawłem Telefusem. Sienieński spłacał również długi po ojcu. Wraz z bratem Janem oddał 800 florenów Markowi Zwiartowskiemu. Andrzej Suchodolski skwitował $z$ kolei Pawła ze wszystkich procesów, które toczyli w urzędzie grodzkim urzędowskim oraz w Trybunale Koronnym. W 1649 r. najstarszy z kasztelaniców lubelskich przeją po bracie Janie arendę dzierżawy przybysławickiej, która ten ostatni uzyskał od marszałka wielkiego koronnego Łukasza Opalińskiego i jego żony Elżbiety z Firlejów. Dnia 9 marca 1654 r. Paweł Sienieński zawarł w Nieszowej kontrakt ze swoim szwagrem Stanisławem Lanckorońskim. W imieniu własnym oraz bratanka Stanisława odprzedał wówczas Lanckorońskiemu za 12 tys. florenów prawa do spadku po przyrodnim bracie Tomaszu. Zobowiązał się również bronić szwagra przed ewentualnymi pretensjami przyrodniej siostry Eufrozyny Humienieckiej. Lanckoroński miał przekazać Sienieńskiemu całą uzgodnioną sumę 24 czerwca 1655 r., a gdyby tego nie zrobił, miał oddać mu w posesję wieś Bór i płacić corocznie prowizję w wysokości 1200 florenów $^{74}$.

Paweł Sienieński, wnuk Teodory z Sapiehów Leńkowej, został uwzględniony w testamencie zmarłego w styczniu 1656 r. podkanclerzego litewskiego Kazimierza Leona Sapiehy. Otrzymał bowiem zapis dożywocia na miasteczku Zelwa $z$ przyległymi wsiami w powiecie wołkowyskim w województwie nowogródzkim. Przeniósł się wówczas na Litwę. Żoną Pawła była poślubiona w 1632 r. Elżbieta Tarnowska h. Leliwa, córka Jana Gratusa (zm. 1626), kasztelana żarnowskiego, i Anny Korniaktówny h. Crucini. Po śmierci Pawła Sienieńskiego Elżbieta $z$ Tarnowa przejęła dożywocie na Zelwie $z$ przyległościami. $Z$ dóbr tych zrezygnowała jednak (w zamian za rekompensatę pieniężna) na rzecz marszałka wielkiego litewskiego Aleksandra Hilarego Połubińskiego. Dnia 27 października 1673 r. Sienieńska dokonała stosownego wpisu $\mathrm{w}$ tej sprawie w księgach grodzkich krakowskich. Stąd wiemy, że Paweł Sienieński zmarł przed tą datą, a wdowa po nim w jakiś

${ }^{74}$ Por. APL, LGR, nr 62, k. 515-515v; nr 64, k. 124v-125; nr 77, k. 566; nr 104, k. 1445-1448 (tu oblata umowy Pawła Sienieńskiego ze Stanisławem Lanckorońskim z 9 III 1654 r.); LZWZ, nr 111, k. 668v, 822v-823. 
czas później ${ }^{75}$. Z małżeństwa $z$ Elżbietą Tarnowską Paweł Sienieński miał co najmniej dwóch synów, Jana i Aleksandra (Aleksandra Dominika). Nie można jednak wykluczyć tego, że pozostawił po sobie również inne dzieci.

Kolejny przedstawiciel rodziny Sienieńskich - Jan w znanych mi źródłach nigdy nie został nazwany expressis verbis synem Pawła. Niemniej jednak $z$ pewnościa nim był. Po raz pierwszy pojawił się on w grodzie lubelskim w 1660 r., kiedy prezentował tu ciało swojego stryja, infamisa Stanisława zabitego we wsi Bór. Na podstawie innych wpisów $z$ ksiag lubelskich $z$ pełnym przekonaniem możemy stwierdzić, że jedynie syn Pawła mógł wówczas zostać nazwany bratankiem Stanisława. Zapewne ten sam Jan ożenił się później z Magdaleną Wieszczycką h. Grzymała, córką Krzysztofa, zamożna wdowa po Mikołaju Branickim h. Korczak, dożywotniczka na wsiach Tulniki i Wola Tulnicka. Jako maż Magdaleny uczestniczył w sporach i procesach, które jego żona i jej synowie $z$ pierwszego małżeństwa prowadzili $z$ rodzina Gołuchowskich. Przybrały one na tyle gwałtowny charakter, że w 1671 r. król Michał ustanowił wadium między Sienieńskim a Gołuchowskimi w wysokości 30 tys. florenów. W 1672 r. Magdalena z Wieszczyc Sienieńska sporządziła testament. Zapisała swojemu drugiemu mężowi 5000 florenów i zapewniła mu użytkowanie trzymanych przez siebie dożywotnio dóbr Branickich do czasu wypłacenia mu całej tej sumy. Ostatnia wolę Magdaleny z Wieszczyckich Sienieńskiej potwierdził również wojski sandomierski Paweł Kochanowski, opiekun synów testatorki z pierwszego małżeństwa, który zagwarantował Janowi wypłacenie zapisanej mu przez zmarłą żonę kwoty. Jako posesor Tulnik i Woli Tulnickiej Jan Sienieński występował jeszcze w latach 16731677. Braniccy nie kwapili się bowiem $z$ wypłaceniem zapisanego mu przez ich matkę legatu. W 1677 r. Jan Sienieński procesował się z pasierbami, Adamem i Mikołajem Branickimi. Dnia 26 czerwca tego roku złożył w grodzie lubelskim protestacje przeciwko obu braciom o gwałtowne odjęcie mu użytkowanych $z$ zapisu zmarłej żony dóbr ${ }^{76}$. Dalsze losy Jana Sienieńskiego nie są znane. $Z$ małżeństwa $z$ Magdaleną Wieszczycką nie pozostawił żadnego potomstwa.

75 Por. ANK, CCI, nr 300, s. 3066-3067; W. Dworzaczek, Hetman Jan Tarnowski. $Z$ dziejów możnowładztwa małopolskiego, Warszawa 1985, s. 350-351.

${ }^{76}$ Por. APL, LGR, nr 86, k. 762v; nr 97, k. 675-676v, 723-724, 824v-828, 838843, 864v-865, 1012v-1013, 1120v-1121v; nr 98, k. 524v-526v (tu testament Magdaleny z Wieszczyc Sienieńskiej), 526v-529v (tu asekuracja ze strony Pawła Kochanowskiego); nr 99, k. 216-217v; nr 101, k. 870-871v, 920v-922. 
O Aleksandrze (Aleksandrze Dominiku), drugim synu Pawła Sienieńskiego i Elżbiety Tarnowskiej, możemy powiedzieć jedynie tyle, że ożenił się on $z$ Eufrozyną Połubińską h. Połubieniec (Jastrzębiec odm.) i miał $z$ nia przynajmniej dwóch synów. Jednym $z$ nich był Dominik (zm. 1743), biskup tytularny maronicki, kanonik warmiński, gnieźnieński, tarnowski i krakowski. Jest on zarazem drugim przedstawicielem lubelskiej linii rodu Sienieńskich, który doczekał się biogramu w Polskim słowniku biograficznym. O Dominiku Sienieńskim wiemy na pewno, że był wnukiem Pawła i Elżbiety Tarnowskiej. Znamy również imię i nazwisko jego drugiej babki. Kiedy 8 stycznia 1723 r. został wprowadzony do kapituły krakowskiej, stwierdził bowiem, że jest synem Dominika Sienieńskiego $z$ województwa sandomierskiego i Eufrozyny Połubińskiej z województwa nowogródzkiego. Jako babkę ojczystą wskazał Elżbietę Tarnowską, a jako babkę macierzystą - Ludwikę Tyszkiewiczównę h. Leliwa. Wiemy także, że tytularny biskup maronicki miał przynajmniej jednego brata. Synem tego ostatniego był bowiem ksiądz Stanisław Dominik Sienieński, na rzecz którego Dominik zrzekł się dziekanii gnieźnieńskiej w 1731 r. Bratanek biskupa był później także kanonikiem kruszwickim oraz proboszczem w Oksywiu i Chylonii ${ }^{77}$. Męskich potomków tej linii Sienieńskich było z pewnością więcej. Możemy bowiem w tym miejscu wysunąc graniczace $z$ pewnościa przypuszczenie, że potomkami kasztelanica lubelskiego Pawła Sienieńskiego i Elżbiety z Tarnowskich byli wszyscy Sienieńscy z Sienna czynni w XVIII w. na Litwie w powiecie wołkowyskim.

Jan Sienieński był młodszym synem kasztelana lubelskiego Zbigniewa i jego pierwszej żony, Anny Leńkówny z Rokitnicy. Jak się wydaje, po śmierci ojca nie objął żadnych dóbr w województwie lubelskim. Dysponował jednak sporymi zasobami gotówki, która lokował na leżących w tym województwie dobrach. W 1638 r. wzią w zastaw za 18 tys. florenów dwie wsie i część trzeciej od Krzysztofa

77 Por. J. Dygdała, Sienieński Dominik, [w:] PSB, t. XXXVII, s. 172-173; J. Dębski, Trybnał Niebieski Na Ziemi Vice Boski z Bogiem Pod Prezydencya Krzyża W Jaśnie Wielmożnym Jegomości Xiędzu Dominiku Na Siennie Sieninskim, Dziekanie Gnieznienskim [...] Jaśnie Osvvieconego Trybunału Koronnego Prezydencie, Kalisz 1721 (tu informacja, że Dominik Sienieński był wnukiem Tarnowskiej i synem Eufrozyny Połubińskiej); K.R. Proko p, Wypisy źródłowe do biografii polskich biskupów i opatów z czasów Rzeczpospolitej Obojga Narodów oraz niewoli narodowej doby zaborów (XVI-XIX w.), cz. 4, „Archiwa, Biblioteki i Muzea Kościelne" 2006, t. LXXXV, s. 353 (tu zeznanie Dominika przy obejmowaniu kanonii krakowskiej). 
z Olbrachcic Bielskiego. W 1646 r. za 6000 florenów zastawili mu część miasteczka Prawno jego przyrodni bracia: Mikołaj, Stanisław, Zbigniew i Tomasz Sienieńscy. Wcześniej oddali mu także, na tych samych zasadach, Mazanów $z$ folwarkiem i Krasne, na których Jan ulokował 18 tys. florenów. W roku 1646 Jan Sienieński uzyskał także intromisję do Krężnicy Jarej, która właściciel tej wsi, Zbigniew Gorajski zastawił mu za 20 tys. florenów. W tym samym roku kasztelanic lubelski scedował zastaw na Prawnie, Mazanowie i Krasnem Jakubowi Uhrowieckiemu, któremu dał także intromisję w te dobra. W 1647 r. Jan Sienieński obją w posiadanie należąca do Jana Myszkowskiego wieś Boiska, którą trzymać miał modo obligatorio w kwocie 18 tys. florenów. W 1648 r. wziąl wreszcie w dzierżawę za 4000 florenów Przybysławice i Wolę Przybysławicka, królewszczyzny należące do marszałka wielkiego koronnego Łukasza Opalińskiego i jego żony Elżbiety z Firlejów. Jan Sienieński zmarł najpewniej już w 1649 r., kiedy arenda Przybysławic przeszła w ręce jego brata Pawła. Nie żył już na pewno 24 marca 1650 r. Żoną Jana Sienieńskiego była Zuzanna $z$ Tarnawki, wdowa po Mikołaju Jaślikowskim. Żyła ona jeszcze w 1658 r., kiedy na podstawie pretensji w kwocie 3000 florenów usiłowała bezskutecznie uzyskać intromisję do wsi Zakrzówek, stanowiącej własność synów nieżyjącego już Adama Suchodolskiego i ich matki, Zofii $z$ Goraja $^{78}$. Nie wiemy niestety, czy pochodzaca $z$ niezbyt świetnej, bardzo rozrodzonej (w istocie drobnoszlacheckiej) rodziny Tarnawieckich Zuzanna była jedyną żoną Jana Sienieńskiego. Nie mamy też pewności, czy była ona matką jego syna Stanisława.

Stanisław Sienieński był jedynym synem Jana, wnukiem kasztelana lubelskiego Zbigniewa, i kasztelanki derpskiej Anny Leńkówny z Rokitnicy. Ponieważ urodził się on przed rokiem 1630, należy przypuszczać, że jego matką była nieznana, pierwsza żona Jana Sienieńskiego. W 1650 r. Stanisław bez powodzenia usiłował wejść w posiadanie wsi Grabówki, do właściciela której, Jana Czermińskiego zgłaszał pretensje o dług w wysokości 2000 florenów. To on był zapewne tym Stanisławem Sienieńskim, który na popisie żołnierza łanowego województwa lubelskiego w 1653 r. wystawił jednego jeźdźca wspólnie z Markiem Zwiartowskim. W latach 1669-1670 Sienieński procesował się z Franciszkiem Borowskim,

78 Por. APL, LGR, nr 67, k. 502-502v; nr 74, k. 600v-601, 644-644v, 721v713v; nr 75, k. 783; nr 76, k. 459-459v; nr 78, k. 279v-280 (tu Stanisław, syn nieżyjącego już Jana); nr 81, k. 755v-756; nr 83, k. 1415v-1416v. 
który dopuścił się zabójstwa jego sługi. Stanisław zgłosił też pretensje do spadku po swoim stryju, mieczniku chełmskim Zbigniewie. W 1673 r. pozywał Jana Zbigniewa Oleśnickiego, kolejnego męża Katarzyny Lanckorońskiej, wdowy po mieczniku chełmskim o należna mu spłatę części sumy zastawnej, w której Zbigniew trzymał niegdyś Kaliszany z przyległościami. W październiku 1675 r. otrzymał spłatę tej należności w wysokości 1500 florenów od drugiej żony nieżyjącego już Oleśnickiego Anny Stanisławskiej ${ }^{79}$. Dalsze losy Stanisława Sienieńskiego nie sa znane.

Pora przejść do przedstawienia dziejów życia synów kasztelana lubelskiego Zbigniewa $z$ jego drugiego małżeństwa. Najstarszy $z$ nich - Mikołaj w chwili śmierci ojca mógł mieć co najwyżej niespełna 12 lat. Kiedy umarła jego matka, był młodzieńcem około 18-letnim. Na niego też w dużym stopniu spadła odpowiedzialność za losy młodszych braci. Młodzi Sienieńscy wielokrotne stawiali się w grodzie lubelskim. Najczęściej też wspólnie występowali w różnego rodzaju sprawach urzędowych. Wkrótce też miało się okazać, że chociaż ich matka, Krystyna z Uhrowieckich Sienieńska spłaciła wierzycieli kasztelana lubelskiego i pozostawiła synom dobra nieobciążone długami, to ci ostatni nie potrafili utrzymać ich w swoim ręku. Wielokrotnie też wydzierżawiali i zastawiali należące do nich majątki. Prowadzili też liczne procesy $z$ sąsiadami, dzierżawcami i posesorami zastawnymi swoich wiosek. Wśród spraw z udziałem wszystkich czterech synów Zbigniewa Sienieńskiego i Krystyny Uhrowieckiej znalazły się spory z Bobowskimi, Adamem Hynkiem, Janem Iżyckim, Wojciechem Węgleńskim i Remigianem Kiełczewskim. W 1646 r. Jan Sienieński, syn kasztelana lubelskiego $z$ pierwszego małżeństwa, scedował swój zastaw na Prawnie, Mazanowie i Krasnem podstolemu chełmskiemu Jakubowi Uhrowieckiemu. W 1647 r. jego młodsi bracia zastawili Uhrowieckiemu kolejnych sześć wiosek: Nieszowę, Basonię, Kolczyn, Rybitwy, Bór i Wolę Judaszową. Oddali mu też te dobra w realną posesję. $Z$ dóbr odziedziczonych po rodzicach czterej kasztelanice lubelscy zatrzymali więc w swoim ręku jedynie Kaliszany, Ostrów i Łopoczno oraz część w Bobach i Wolę Lubaszową. Wszyscy czterej

${ }^{79}$ Por. APL, LGR, nr 78, k. 279v-280, 631v-632v; nr 81, k. 1121; nr 95, k. 1051-1052; nr 96, k. 1802-1803; nr 99, k. 662v-663v; J. Pielas, Oleśniccy herbu Dębno w XVI-XVII wieku. Studium z dziejów zamożnej szlachty doby nowożytnej, Kielce 2007, s. 351 . 
bracia uczestniczyli też w procesach $z$ sąsiadami Kaliszan (Kowalskim i Silnickim) toczonych w latach 1647-164980.

Reprezentantem interesów rodziny w dalszym ciagu był przede wszystkim Mikołaj. Dnia 21 października 1645 r. zawarł on w Lublinie intercyzę $z$ Zofia $z$ Chodorowskich Krzycka, żona Adama, starosty ejszyskiego, oraz jej synami z poprzedniego małżeństwa, Stanisławem, Janem i Jakubem Podoskimi. Zgodnie $z$ warunkami tej umowy Sienieński miał poślubić Konstancję Podoska, córkę Jana, wojewody mazowieckiego, a jej matka i bracia mieli do 6 stycznia 1646 r. przekazać mu posag żony w wysokości 8000 florenów. Mikołaj twierdził później, że w intercyzie znalazł się również zapis mówiący o tym, że w przypadku niewypłacenia w terminie posagu Podoscy oddadzą mu w użytkowanie wieś Świerczów w ziemi chełmskiej. Ponieważ ani starościna ejszyska, ani też wojewodzice mazowieccy nie wywiązali się $z$ uzgodnionych w Lublinie warunków, stosunki między Sienieńskim a rodzina jego żony od początku nie ułożyły się dobrze. W 1647 r. wizytę we dworze w Kaliszanach złożyli bracia Konstancji z Podosia Sienieńskiej - rodzony Stanisław i przyrodni Mikołaj Stefan Łaszcz. Goście, grożąc Mikołajowi spaleniem dworu, sprowokowali awanturę, która zakończyła się bijatyką. W czasie bójki ranny został młodszy, nieletni brat gospodarza, Zbigniew oraz kilku jego służących. Sprawa miała oczywiście swój dalszy ciąg w postaci pozwów, jakie złożył Mikołaj w imieniu swoim i brata przeciwko własnej teściowej, Zofii z Chodorostawu $1^{\circ} \mathrm{v}$. Stefanowej Łaszczowej $2^{\circ} \mathrm{v}$. Janowej Podoskiej $3^{\circ} \mathrm{v}$. Adamowej Krzyckiej oraz obu szwagrom. Zarówno Mikołaj Stefan Łaszcz, jak i Stanisław Podoski zostali skazani na banicję i infamię. Rzecz jasna sprawa ta tylko pogorszyła relacje Mikołaja $z$ rodzina żony. W roku 1651 pozostali bracia Konstancji Sienieńskiej (Stanisław Podoski zmarł już w 1648 r.) udaremnili podjęta przez jej męża próbę intromisji do Świerczowa. W tym samym roku Mikołaj i Zbigniew Sienieńscy pozwali też Aleksandra Podoskiego w związku ze stara sprawa awantury w Kaliszanach z udziałem Mikołaja Stefana Łaszcza i Stanisława Podoskiego ${ }^{81}$.

${ }^{80}$ Por. APL, LGR, nr 69, k. 61v-62; nr 73, k. 501v-502; nr 74, k. 968v-969; nr 75, k. 18-18v, 763v-764, 1100v-1101; nr 76, k. 625v-626; nr 77, k. 170v-172.

${ }^{81}$ Por. APL, ChGZ, nr 26, s. 707-708; nr 27, s. 644-648 (tu intercyza z $21 \mathrm{X}$ 1645 r.); LGR, nr 75, k. 778, 811v-812v, 1117v-1119; nr 76, k. 32v-34, 37v-42v; nr 79, k. 909-909v. 
Pogłębiające się trudności finansowe synów kasztelana lubelskiego $z$ jego drugiego małżeństwa postanowił wykorzystać ich szwagier, Stanisław Lanckoroński. Stopniowo, krok po kroku, skupował on pretensje wierzycieli Sienieńskich, uzyskiwał cesje zastawów i udzielał im nowych pożyczek. Już w 1650 r. ówczesny wojewoda bracławski podją próbę objęcia w realne posiadanie wszystkich dóbr, które Mikołaj, Stanisław i Zbigniew Sienieńscy odziedziczyli po ojcu i matce. Musiał jednak zrezygnować ze względu na opór Mikołaja oraz innego pretendenta do przejęcia tych majątków, podstolego chełmskiego Jakuba Uhrowieckiego. Nie mogąc przeprowadzić swoich zamiarów per fas, Lanckoroński dokonał zbrojnego zajazdu Nieszowej z przyległymi wioskami. Dnia 18 lutego 1651 r. Stanisław Sienieński w imieniu własnym oraz braci Mikołaja i Zbigniewa złożył w grodzie lubelskim protest przeciwko wojewodzie bracławskiemu i jego wspólnikom (m.in. Janowi, Piotrowi i Andrzejowi Rzeczyckim, starościcom urzędowskim), którzy $z$ tłumem sług i żołnierzy (dragonów $z$ choragwi koniuszego wielkiego litewskiego Bogusława ks. Radziwiłła) zajechali i zajęli sporne dobra. W ostatecznym rozrachunku Stanisław Lanckoroński złamał opór Sienieńskich i prośbą oraz groźbą nakłonił ich do sprzedania pożądanych przez niego majątków. Proces przejmowania przez Lanckorońskiego dawnych dóbr kasztelana lubelskiego Zbigniewa trwał, jak się zdaje, do 1654 r. Jeszcze w 1653 r. Mikołaj Sienieński, wtedy rotmistrz JKM, uzyskał intromisję do Woli Lubaszowej, która w roku poprzednim sprzedał szwagrowi, lecz nie otrzymał całej należności. Szybko jednak musiał ustapić $z$ tej wsi, gdyż w 1653 r. zabrakło już Sienieńskich w spisie ziemian zobowiązanych do wystawienia pocztu na popisie żołnierza łanowego województwa lubelskiego. W 1654 r. Stanisław Lanckoroński jako właściciel Mazanowa zastawił tę wieś Janowi Rzeczyckiemu za 17 tys. florenów ${ }^{82}$.

Ostatnie lata życia Mikołaj Sienieński spędził w Kaliszanach, które jego młodszy brat Zbigniew trzymał w zastawie od Stanisława Lanckorońskiego. W 1654 r. pozywał Aleksandra Podoskiego o niewypłacony posag nieżyjącej już Konstancji z Podosia Sienieńskiej. W tym samym roku napadł na drodze wraz $z$ bratem Zbigniewem ludzi Stanisława Drzewieckiego, odebrał im upolowaną zwierzynę i zabrał psa legawego należącego do kustosza łuckiego, kanonika

${ }^{82}$ Por. APL, LGR, nr 78, k. 327-328, 1002-1002v, 1005v; nr 79, k. 112-115; nr 81, k. 272v; nr 82, k. 1102-1105v. 
krakowskiego i proboszcza urzędowskiego Franciszka Gogolińskiego. Uwikłał się w ten sposób w nowy konflikt, gdyż obaj poszkodowani odpowiedzieli złożeniem pozwów przeciwko Sienieńskim do Kaliszan. W 1656 r. Mikołaj wspólnie z Franciszkiem Uhrowieckim i Łukaszem Wereszczyńskim dokonał zbrojnego zajazdu wsi Świerczów. O napad na swoje dobra i poranienie sług oskarżała ich w 1658 r. ówczesna właścicielka tej wsi, wdowa po instygatorze koronnym Danielu Żytkiewiczu, Anna z Biórkowa Szembergówna. W tym samym roku Mikołaj Sienieński został poraniony na Krakowskim Przedmieściu w Lublinie przez ludzi Aleksandra Hilarego Połubińskiego. Niedługo później porzucił stan świecki i został zakonnikiem. Zmarł przed 17 marca 1660 r. $Z$ małżeństwa $z$ wojewodzianką mazowiecką Konstancją Podoską h. Junosza pozostawił jedynie córkę Konstancję $e^{83}$.

O Konstancji, jedynej córce Mikołaja i Konstancji Podoskiej, wiemy jedynie to, że jeszcze jako panna procesowała się w $1660 \mathrm{r}$. $z$ wdowa po Danielu Żytkiewiczu o wieś Świerczów w ziemi chełmskiej, do której miała prawa po matce. Była też wymieniana w gronie spadkobierców stryja Zbigniewa, miecznika chełmskiego. W roku 1667 pozywała swoich braci stryjecznych, synów Stanisława, o 440 florenów. W 1669 r. była już żona Pawła Kurdwanowskiego h. Półkozic. Wraz z mężem zawarła umowę z Janem Zbigniewem Oleśnickim, na mocy której ten ostatni miał jej wypłacić 1500 florenów stanowiących ostatnią część spłaty należnej spadkobiercom miecznika chełmskiego Zbigniewa Sienieńskiego. Konstancja $z$ Sienna Kurdwanowska nie doczekała jednak finalizacji tego układu. Zmarła przed 30 października 1675 r., gdy wdowa po Oleśnickim wypłaciła wspomniana sumę jej bratu stryjecznemu (synowi Jana) Stanisławowi Sienieńskiemu ${ }^{84}$.

Stanisław Sienieński był drugim synem kasztelana lubelskiego Zbigniewa i Krystyny Uhrowieckiej. $Z$ treści testamentu jego matki wynika, że chciała ona, aby został księdzem. Ostatecznie jednak nie zdecydował się on na karierę duchowną. Uczestniczył niemal we wszystkich sprawach sadowych, w których strona był

${ }^{83}$ Por. APL, LGR, nr 82, k. 619v-621v, 1228-1228v, 1339v-1340; nr 83, k. 720$724 \mathrm{v}$ (tu informacja, że jeden $\mathrm{z}$ pozwów przeciwko uczestnikom napadu na Świerczów złożono w Woli Lubaszowej, co może sugerować, że Mikołaj Sienieński przebywał wówczas w tej właśnie wsi), 1008v-1009v; nr 86, k. 157-158 (tu informacja, że Mikołaj przed śmiercia został duchownym).

${ }^{84}$ Por. APL, LGR, nr 86, k. 157-158; nr 93, k. 24-25; nr 95, k. 247-247v; J. Pielas, op. cit., s. 351. 
jego starszy brat Mikołaj. W 1651 r. samodzielnie występował przeciwko Wojciechowi, Łukaszowi i Franciszkowi Patrzyckim, spadkobiercom nieżyjącego już Stanisława Patrzyckiego, który był jednym z uczestników dokonanego przez Stanisława Lanckorońskiego zajazdu na Nieszowę i inne dobra Sienieńskich. Nie wiemy niestety, za jakie przestępstwo Stanisław Sienieński został skazany na infamię. Jako infamis został zabity w 1660 r. we wsi Bór przez ludzi swojego siostrzeńca, starosty skalskiego Przecława Lanckorońskiego. Jego ciało prezentował w grodzie lubelskim Jan Sienieński, syn przyrodniego brata Stanisława, Pawła. Stanisław Sienieński ożenił się Magdaleną Wasilkowską, z która miał dwóch synów, Zbigniewa i Jana Aleksandra. Wdowa po Stanisławie żyła jeszcze w 1665 r. Procesowała się bowiem wówczas $z$ urzędem grodzkim lwowskim, Patrzyckimi i lwowska gminą żydowską o należną jej kwotę 7000 florenów ${ }^{85}$.

W 1660 r. synowie Stanisława musieli być przynajmniej nastolatkami, gdyż do nich właśnie adresowany był dekret królewski $\mathrm{w}$ sprawie $\mathrm{z}$ Patrzyckimi, pozywającymi obu braci Sienieńskich o długi pozostawione przez ich ojca. O starszym $z$ synów Stanisława, Zbigniewie możemy powiedzieć jedynie to, że został on odnotowany w księgach grodzkich lubelskich w 1660 r. przy okazji procesu $z$ Patrzyckimi. Ponownie w 1667 r., gdy $z$ bratem został pozwany przez siostrę stryjeczną Konstancję o zwrot 440 florenów. Po raz trzeci zaś wreszcie w 1670 r., gdy Sienieńscy, tym razem jako spadkobiercy matki i „adherenci” Żydów lwowskich, ponownie musieli odpierać pretensje Patrzyckich kierowane do nich oraz do lwowskiego urzędu grodzkiego i tamtejszej gminy żydowskiej o bezprawne zajęcie kamienicy należącej do Franciszka Patrzyckiego ${ }^{86}$. Nic więcej o nim nie wiemy. Najpewniej zmarł przed rokiem 1671 bezżennie i bezpotomnie.

Nieco więcej wiemy o drugim synu Stanisława Sienieńskiego i Magdaleny Wasilkowskiej. W źródłach nazywany był on na przemian Janem lub Aleksandrem. Możemy stąd wnosić, że był dwuimienny i nazywał się Jan Aleksander. W 1671 r. oblatował on w grodzie lubelskim intercyzę zawarta w $1653 \mathrm{r}$. w Jagielnicy przez Magdalenę Wasilkowska ze Stanisławem Lanckorońskim, który

85 Por. APL, LGR, nr 73, k. 522-523 (testament Krystyny z Uhrowieckich Sienieńskiej); nr 79, k. 895-896; nr 86, k. 762v, 961-963; nr 91, k. 352-353.

${ }^{86}$ Por. APL, LGR, nr 86, k. 961-963; nr 93, k. 24-25. 
zobowiązał się wówczas wypłacić matce Sienieńskiego 3000 florenów. W 1684 r. był jednym $z$ uczestników procesu z Żydem lubelskim Szmulem Diabłem. W roku 1692 Aleksander Sienieński, jako spadkobierca stryja, miecznika chełmskiego Zbigniewa, uzyskał w sądzie grodzkim lubelskim zgodę na intromisję do wsi Kaliszany. Ponieważ jednak pretensje Sienieńskiego nie miały jakichkolwiek podstaw, ówczesna posesorka tej wsi, Anna Rysińska, wdowa po kasztelanie krakowskim Andrzeju Potockim, nie dopuściła do realizacji tego dekretu. Jest to ostatnia wzmianka źródłowa o młodszym $z$ synów infamisa Stanisława. Wiemy natomiast, że był on żonaty. W 1684 r. w grodzie lubelskim pojawiła się bowiem Katarzyna $z$ Krzętowa $1^{\circ}$ v. Zaporska $2^{\circ}$ v. Aleksandrowa Sienieńska, która pozwała Jana Linowskiego o zwrot 3000 florenów ${ }^{87}$. Nie wiemy niestety nic więcej ani o Janie Aleksandrze, ani też o jego małżonce.

Zbigniew Sienieński był trzecim synem kasztelana lubelskiego Zbigniewa i Krystyny Uhrowieckiej. Wspominano już o nim wielokrotnie we wcześniejszych partiach tekstu. W tym miejscu dodajmy tylko, że w 1653 r. zawarł on ze swoim szwagrem, Stanisławem Lanckorońskim umowę, na mocy której wzią w zastaw za 37 tys. florenów wsie Kaliszany, Łopoczno i Ostrów seu Grodzisko. Paradoks całej tej sytuacji polegał na tym, że dobra te jeszcze niedawno stanowiły własność synów kasztelana lubelskiego, od których dopiero co kupił je Lanckoroński. Zbigniew Sienieński ożenił się $z$ Katarzyną $z$ Brzezia Lanckorońską h. Zadora. Była ona córka Marcina Lanckorońskiego i Krystyny z Kozietulskich, a więc bratanica hetmana Stanisława. Suma zastawu na Kaliszanach nie stanowiła bynajmniej posagu, jaki Katarzyna wniosła Zbigniewowi. Odziedziczyli ja bowiem później jego spadkobiercy, a wdowa miała jedynie prawo do dożywotniego użytkowania zastawionych przez Stanisława Lanckorońskiego dóbr. Pod koniec życia Zbigniew Sienieński uzyskał prawdopodobnie tytularny urząd miecznika chełmskiego. Zmarł przed dniem 4 lutego 1656 r. Z małżeństwa z Katarzyną Lanckorońska pozostawił jedynie córkę Krystynę. Zmarła ona jednak w wieku zaledwie kilku lat około roku 1662. Wdowa po Zbigniewie jeszcze dwukrotnie wychodziła za mąż: najpierw za kasztelana lubelskiego Jerzego Słupeckiego (zm. 1663),

87 Por. APL, LGR, nr 97, k. 382; nr 108, k. 642v-643v; nr 139, k. 540v, 646-649. 
a następnie (w 1668 r.) za Jana Zbigniewa Oleśnickiego. Katarzyna z Brzezia Lanckorońska zmarła przed 30 sierpnia 1669 r. ${ }^{88}$

Tomasz Sienieński był najmłodszym synem kasztelana lubelskiego Zbigniewa i jego drugiej żony, Krystyny Uhrowieckiej. Nigdy nie dane mu było odegrać jakiejkolwiek samodzielnej roli. Jego imię wymieniano w aktach przy okazji różnego rodzaju spraw załatwianych w grodzie lubelskim przez jego starszych braci. W 1650 r. nie uwzględniono już jednak Tomasza, w skargach i protestacjach składanych przez Mikołaja, Stanisława i Zbigniewa Sienieńskich przeciwko Stanisławowi Lanckorońskiemu. Najpewniej zatem musiał już wówczas umrzeć. Jako zmarły został odnotowany w początkach czerwca 1652 r. Rodziny z całą pewnością nie zdążył założyćc9.

Na koniec spróbujmy pokusić się o kilka spostrzeżeń bardziej ogólnej natury. Po pierwsze, w kilkudziesięcioosobowej grupie zidentyfikowanych przedstawicieli lubelskiej linii Sienieńskich żyjących w XVI i XVII w. było łącznie 27 mężczyzn i 20 kobiet. Liczba ta mogłaby pewnie się zwiększyć, gdyby udało się zdobyć informacje o sytuacji rodzinnej Pawła Macieja Sienieńskiego, który oprócz synów Aleksandra Dominika i Jana miał prawdopodobnie również

88 Por. APL, LGR, nr 139, k. 540v; AGAD, Archiwum Zamoyskich, sygn. 2830, s. 49 (tu Katarzyna Lanckorońska nazwana córka Marcina i Krystyny z Kozietulskich), s. 51, 53, 57, 61, 65, 86, 91 (tu we wszystkich cytowanych dokumentach Krystyna Sienieńska jako jedyna córka i spadkobierczyni Zbigniewa); Urzędnicy województwa bełskiego i ziemi chełmskiej XIV-XVIII wieku. Spisy, oprac. H. Gmiterek i R. Szczygieł, red. A. Gassiorowski, Kórnik 1992, nr 1169 (w tym miejscu należy jednak zaznaczyć, że w żadnym ze znanych mi dokumentów Zbigniew Sienieński nie został nazwany miecznikiem chełmskim); J. Pielas, op. cit., s. 393-394 (tu błędna sugestia, że żona Zbigniewa, Katarzyna z Brzezia Lanckorońska była córką jego szwagra Stanisława). Warto w tym miejscu wspomnieć, że również synowie wojewody ruskiego Stanisława Lanckorońskiego nie zdołali utrzymać w swoich rękach dóbr kupionych przez ojca od Sienieńskich. W lipcu 1667 r. wszystkie bez wyjątku osady należące niegdyś do synów kasztelana lubelskiego Zbigniewa i Krystyny Uhrowieckiej były bowiem użytkowane już przez nowych posesorów. W przypadku Kaliszan i Łopoczna zaznaczono, że prawo do zastawu na tych dobrach maja Katarzyna $z$ Brzezia Słupecka, kasztelanowa lubelska oraz spadkobiercy jej pierwszego męża: Zbigniew i Jan Aleksander Sienieńscy, synowie Stanisława oraz Konstancja, córka Mikołaja. Por. APL, LGR, nr 93, k. 1043-1050v. Dodajmy także, że wieś Chroślina, należąca niegdyś do Pawła i Jana Sienieńskich, synów kasztelana lubelskiego $z$ jego pierwszego małżeństwa, też miała wówczas nowego właściciela. W 1667 r. została bowiem odnotowana jako dziedziczna posiadłość Andrzeja Rzeczyckiego. Por. APL, nr 93, k. 1185v-1187.

${ }^{89}$ Por. APL, LGR, nr 80, k. 25v. 
inne dzieci. Zwraca uwage to, że Sienieńscy z Lubelskiego nie byli zbyt czynni na scenie politycznej. Wydali bowiem w badanym okresie jedynie jednego senatora i jednego urzędnika ziemskiego. Niektórzy $z$ nich żenili się jednak $z$ córkami senatorów (Niszczycka, Leńkówną, Tarnowską, Podoską) lub też z pannami pochodzącymi $z$ rodzin senatorskich (Zarembianka, Ligęzianką, Lanckorońska). Córki Sienieńskich szukały natomiast mężów raczej wśród szlachty średniozamożnej. Jedynie jedna (Aleksandra) wyszła za późniejszego senatora. Zwraca też uwagę to, że tylko cztery Sienieńskie zostały w badanym okresie zakonnicami. Dodajmy wreszcie, że dzięki małżeństwom i własnej zapobiegliwości Sienieńscy $z$ linii lubelskiej zdobyli posiadłości poza będącym ich matecznikiem powiatem urzędowskim. Mieli oni dziedziczne majątki w województwach bełskim, krakowskim, sandomierskim, rawskim oraz w ziemi chełmskiej. Różnie potoczyły się też losy potomków trzech synów protoplasty lubelskiej linii rodu. Odnoga na Boiskach wymarła w linii męskiej już na początku XVII w., a jej posiadłości trafiły w obce ręce. Przedstawiciele odnogi na Radomyślu przez dłuższy czas należeli do grupy zamożnych ziemian lubelskich. Najbardziej czynni byli natomiast potomkowie najmłodszego syna Wiktoryna Sienieńskiego - Jana, dziedzica na Chroślinie. Wnuk protoplasty lubelskiej linii rodu - Zbigniew osiągną urząd kasztelana lubelskiego. Zgromadził też największy majątek. Można zatem stwierdzić, że apogeum świetności Sienieńskich $z$ Lubelskiego przypadło na pierwsza połowę XVII w. W drugiej połowie tego stulecia nastąiło jednak gwałtowne załamanie. Podział dóbr między trzech synów Jana Abrahama i sześciu synów kasztelana doprowadził do ich relatywnego zubożenia. Sienieńscy stopniowo tracili swoje posiadłości. Pod koniec XVII w. nie byli już właścicielami żadnego majątku w Lubelskiem, a ostatni potomkowie badanej linii rodu brali już tylko w zastaw wioski należące do innych ziemian. Jak się wydaje, status średnioszlachecki utrzymali tylko potomkowie Pawła Macieja, który w latach pięćdziesiątych XVII w. opuścił Lubelskie i przeniósł się do powiatu wołkowyskiego, gdzie objął w dożywotnie posiadanie sapieżyńską Zelwę. Jego wnuk został w XVIII stuleciu tytularnym biskupem maronickim. 


\section{ANEKS}

\section{Sienieńscy h. Dębno, potomkowie kasztelanica małogoskiego Wiktoryna (gałąź lubelska)}

1. Wiktoryn († p. 21 VI 1559) x 1. Anna N. 2. Jadwiga Leska

\section{I pokolenie}

2. Stanisław († p. 12 III 1601), syn Wiktoryna i Anny x 1. N. Niszczycka 2. Agnieszka Marcinowska

3. Marcin († p. 1571), syn Wiktoryna i Anny

4. Jakub $(\dagger 1601)$, syn Wiktoryna i Anny x 1. Regina Czerna 2. Barbara Pacanowska

5. Andrzej († p. 1571), syn Wiktoryna i Anny

6. Jan zm. († p. 16 III 1592), syn Wiktoryna i Jadwigi Leskiej x NN.

(1) Zofia († po 1602), córka Wiktoryna i Anny x Paweł Czerny z Witowic

\section{II pokolenie}

7. Mikołaj († p. 1616), syn Stanisława i N. Niszczyckiej

8. Jakub († p. 1616), syn Stanisława i N. Niszczyckiej x NN.

(2) Anna († 2 VI 1607), córka Stanisława i N. Niszczyckiej x Krzysztof Żukowski

(3) Katarzyna († p. 17 VIII 1619), córka Stanisława i N. Niszczyckiej x 1. Jan Biejkowski, stolnik przemyski 2. Mikołaj Ostrowski, podsędek przemyski 3. Stanisław Myszkowski, podczaszy lubelski

(4) Zofia († po 1614), córka Stanisława i Agnieszki Marcinowskiej x Stanisław Pacanowski

9. Marcin († ok. 1622), syn Jakuba i Reginy Czernej x 1. Bernardyna Dorota Zarembianka $z$ Kalinowy 2. Katarzyna Ligęzianka $z$ Bobrku

10. Abraham ( $\dagger$ p. 1639), syn Jakuba i Reginy Czernej x Agnieszka Rokoszówna

(5) Elżbieta ( $\dagger$ po 1633), córka Jakuba i Reginy Czernej x 1. Adrian Mikołajowski 2. Jan Białyński 3. Piotr Minocki

11. Zbigniew ( $†$ 1633), syn Jana i NN., kasztelan lubelski x 1. Anna Leńkówna z Rokitnicy 2. Krystyna Uhrowiecka

\section{III pokolenie}

(6) Zofia († p. 25 VI 1626), córka Jakuba i N.N x Stanisław Siedleszczyński

12. Joachim (w. 1608), syn Marcina i Bernardyny Doroty Zarembianki z Kalinowy

13. Jan Abraham († p. 26 I 1648), syn Marcina i Bernardyny Doroty Zarembianki $z$ Kalinowy x Anna Gajowska 
(7) Marianna (w. 1608), córka Marcina i Bernardyny Doroty Zarembianki z Kalinowy

(8) Zofia († po 1630), córka Marcina i Katarzyny Ligęzianki z Bobrku, zakonnica w klasztorze bernardynek w Lublinie

(9) Katarzyna († po 1630), córka Marcina i Katarzyny Ligęzianki z Bobrku, zakonnica w klasztorze bernardynek w Lublinie

(10) Anna († po 1638), córka Marcina i Katarzyny Ligęzianki z Bobrku x Wawrzyniec Kos

14. Paweł ( $\dagger$ po 1656), syn Zbigniewa i Anny Leńkówny z Rokitnicy x Elżbieta Tarnowska

15. Jan († ok. 1649), syn Zbigniewa i Anny Leńkówny z Rokitnicy x 1. NN. 2. Zuzanna Tarnawiecka

(11) Aleksandra († p. 1657), córka Zbigniewa i Anny Leńkówny z Rokitnicy $\mathrm{x}$ Stanisław Lanckoroński, wojewoda ruski i hetman polny koronny

(12) Katarzyna († po 1649), córka Zbigniewa i Anny Leńkówny z Rokitnicy x Piotr Garwaski, starosta rzeczycki

(13) Krystyna († po 1653), córka Zbigniewa i Anny Leńkówny z Rokitnicy, zakonnica w klasztorze bernardynek w Lublinie

16. Mikołaj (*ok. $1621 \dagger$ p. 1660), syn Zbigniewa i Krystyny Uhrowieckiej x Konstancja Podoska

17. Stanisław († 1660), syn Zbigniewa i Krystyny Uhrowieckiej x Magdalena Wasilkowska

18. Zbigniew ( $\dagger$ p. 4 II 1656), syn Zbigniewa i Krystyny Uhrowieckiej, miecznik chełmski x Katarzyna z Brzezia Lanckorońska

19. Tomasz († ok. 1650), syn Zbigniewa i Krystyny Uhrowieckiej

(14) Anna († 1684), córka Zbigniewa i Krystyny Uhrowieckiej, zakonnica w klasztorze bernardynek w Lublinie

(15) Eufrozyna († po 1654), córka Zbigniewa i Krystyny Uhrowieckiej x N. Humieniecki

\section{IV pokolenie}

20. Aleksander ( $†$ p. 2 XI 1690), syn Jana Abrahama i Anny Gajowskiej, kanonik kamieniecki

21. Abraham († po 1696), syn Jana Abrahama i Anny Gajowskiej x Dorota Roszkowska

22. Jan Mikołaj ( $†$ p. 17 VIII 1684), syn Jana Abrahama i Anny Gajowskiej x Anna Rzeczycka

(16) Krystyna († po 1688), córka Jana Abrahama i Anny Gajowskiej x Jan Piotraszowski

(17) Marianna († po 1688), córka Jana Abrahama i Anny Gajowskiej x Aleksander $z$ Więcborka Zebrzydowski

(18) Izabela († p. 1688), córka Jana Abrahama i Anny Gajowskiej x Maciej Kozicki 
23. Jan († po 1677), syn Pawła i Elżbiety Tarnowskiej x Magdalena Wieszczycka

24. Aleksander Dominik (†?), syn Pawła i Elżbiety Tarnowskiej x Eufrozyna Połubińska

25. Stanisław ( $†$ po 1675), syn Jana i NN., wnuk Zbigniewa i Anny Leńkówny z Rokitnicy

(19) Konstancja († p. 1675), córka Mikołaja i Konstancji Podoskiej x Paweł Kurdwanowski

26. Zbigniew ( $†$ ok. 1670), syn Stanisława i Magdaleny Wasilkowskiej

27. Jan Aleksander ( $†$ po 1692), syn Stanisława i Magdaleny Wasilkowskiej x Katarzyna Krzętowska

(20) Krystyna († ok. 1662), córka Zbigniewa i Katarzyny Lanckorońskiej

\section{V pokolenie}

28. Dominik ( $†$ 1743), syn Aleksandra Dominika i Eufrozyny Połubińskiej, biskup tytularny maronicki, kanonik warmiński, gnieźnieński, tarnowski i krakowski

29. NN., syn Aleksandra Dominika i Eufrozyny Połubińskiej x NN.

\section{VI pokolenie}

30. Stanisław Dominik ( $\dagger$ po 1754), syn NN. syna Aleksandra Dominika i Eufrozyny Połubińskiej, kanonik kruszwicki, dziekan gnieźnieński, proboszcz oksywski i chyloński

\section{Bibliografia}

\section{Ź RódeA ARChIWALNE}

Archiwum Główne Akt Dawnych w Warszawie [AGAD]

Archiwum Zamoyskich, sygn. 2830.

Metryka Koronna [MK] 15, 147, 159, 178, 180, 185.

Archiwum Narodowe w Krakowie [ANK]

Castriensia Cracoviensia Inscriptiones [CCI], nr 89, 90, 107, 112, 220, 226, 227, 228, 229, 230, 231, 233, 234, 235, 237, 238, 239, 243, 244, 248, 268, 277, 300, 302 .

Grodzkie bieckie, Inskrypcje i relacje, nr 18.

Archiwum Państwowe w Lublinie [APL]

Chełmskie grodzkie, Zapisy [ChGZ], nr 19, 20, 21, 26, 27.

Lubelskie grodzkie, Relacje [LGR], nr 30, 36, 37, 42, 44, 46, 47, 48, 49, 52, $53,54,55,57,58,59,61,62,63,64,67,69,73,74,75,76,77,78,79,80,81$, $82,83,84,85,86,91,92,93,94,95,96,97,98,99,100,101,102,103,104$, 105, 107, 108, 111, 113, 114, 120, 122, 127, 129, 139, 140, 148, 153, 158, 164. 
Lubelskie ziemskie, Sądowe [LZS], nr 51, 54, 60.

Lubelskie ziemskie, Wieczyste [LZW], nr 80, 81, 82, 83, 84, 87.

Lubelskie ziemskie, Wieczyste i zobowiązania [LZWZ], nr 106, 108, 109, 111.

Lubelskie ziemskie, Zobowiązania [LZZ], nr 102.

Archiwum Państwowe w Rzeszowie

Archiwum Lubomirskich, sygn. 16.

Biblioteka Książąt Czartoryskich - Muzeum Narodowe w Krakowie sygn. 1286 Perg.

Biblioteka Narodowa w Warszawie

Łuszczyński B.H., Silva heraldica, t. IV, rękopis, sygn. IV 5582.

Łuszczyński B.H., Silva heraldica, t. V, rękopis, sygn. IV 5582.

Łuszczyński B.H., Silva heraldica, t. VI, rękopis, sygn. IV 5582.

Łuszczyński B.H., Silva heraldica, t. VII, rękopis, sygn. IV 5582.

\section{ŹŹóDEA DRUKOWANE}

Akta grodzkie i ziemskie z czasów Rzeczypospolitej Polskiej z Archiwum tak zwanego bernardyńskiego we Lwowie, t. XX (Lauda sejmikowe), t. I (Lauda wiszeńskie 1572-1648 r.), oprac. A. Prochaska, Lwów 1909.

Akta sejmikowe województwa bełskiego. Lata 1572-1655, wyd. M. Zwierzykowski i R. Kołodziej, Kraków 2020.

Archiwum Jana Zamoyskiego, kanclerza i hetmana wielkiego koronnego, t. I (15531579), wyd. W. Sobieski, Warszawa 1904.

Dębski J., Trybnał Niebieski Na Ziemi Vice Boski z Bogiem Pod Prezydencya Krzyża W Jaśnie Wielmożnym Jegomości Xiędzu Dominiku Na Siennie Sieninskim, Dziekanie Gnieznienskim [...] Jaśnie Osvvieconego Trybunału Koronnego Prezydencie, Kalisz 1721.

Niesiecki K., Herbarz polski, wyd. J.N. Bobrowicz, t. VI, Lipsk 1841.

Niesiecki K., Herbarz polski, wyd. J.N. Bobrowicz, t. VIII, Lipsk 1841.

Orzelski Ś., Bezkrólewia ksiag ośmioro, czyli dzieje Polski od zgonu Zygmunta Augusta r. 1572 aż do r. 1576, oprac. W. Spasowicz, Petersburg 1858.

Pamiętnik Jakuba Pszonki $z$ autografu $w$ bibliotece Ossolińskich znajdujacego się wydany. Inwentarz Skarbu Koronnego z roku 1607, wyd. A. Bielowski, Lwów 1874.

Paprocki B., Herby rycerstwa polskiego, wyd. K.J. Turowski, Kraków 1858.

Polska południowo-wschodnia $w$ epoce nowożytnej. Źródła dziejowe, t. I, cz. 1 (Rejestr poborowy ziemi przemyskiej z 1628 roku), wyd. Z. Budzyński, K. Przyboś, Rzeszów 1997.

Polska południowo-wschodnia w epoce nowożytnej. Źródła dziejowe, t. I, cz. 2 (Rejestr poborowy ziemi przemyskiej z 1651 roku), wyd. Z. Budzyński, K. Przyboś, Rzeszów 1997. 
Polska południowo-wschodnia $w$ epoce nowożytnej. Źródła dziejowe, t. II, cz. 1 (Rejestr poborowy ziemi sanockiej z 1640 roku), wyd. Z. Budzyński, K. Przyboś, Rzeszów 1998.

Prokop K.R., Wypisy źródłowe do biografii polskich biskupów i opatów z czasów Rzeczpospolitej Obojga Narodów oraz niewoli narodowej doby zaborów (XVI-XIX w.), cz. 4, „Archiwa, Biblioteki i Muzea Kościelne” 2006, t. LXXXV, s. 305-377.

Rejestr poborowy województwa krakowskiego z roku 1629, oprac. W. Domin, J. Kolasa, E. Trzyna, S. Żyga, red. S. Inglot, Wrocław 1956.

Rejestr poborowy województwa lubelskiego (powiat lubelski i urzędowski z r. 1626, ziemia łukowska z r. 1620), oprac. J. Kolasa i K. Schuster, red. S. Inglot, Wrocław 1957.

Źródła dziejowe, t. XVIII, cz. 1 (Polska XVI wieku pod względem geograficzno-statystycznym), t. VII (Ziemie ruskie. Ruś Czerwona), cz. 1, wyd. A. Jabłonowski, Warszawa 1902.

\section{Opracowania}

Anusik Z., Garwascy herbu Grzymała w XV-XVII wieku. Przyczynek do dziejów i genealogii rodu, „Przegląd Nauk Historycznych” 2015, R. XIV, nr 2, s. 25-83.

Anusik Z., Krag rodzinny Katarzyna z Sienna Myszkowskiej (zm. 1619), podczaszyny lubelskiej. Studium genealogiczno-obyczajowe, „Przegląd Nauk Historycznych” 2020, R. XIX, nr 2, s. 245-280. https://doi.org/10.18778/1644$-857 X .19 .02 .10$

Anusik Z., Struktura własności ziemskiej $w$ powiecie pilzneńskim $w$ roku 1629, „Przegląd Nauk Historycznych” 2011, R. X, nr 2, s. 69-108.

Borkowska M., Zakonnice pominięte $w$ tablicach Dworzaczka, „Nasza Przeszłość” 2002 , t. XCVII, s. 259-302.

Dubas-Urwanowicz E., Koronne zjazdy szlacheckie $w$ dwóch pierwszych bezkrólewiach po śmierci Zygmunta Augusta, Białystok 1998.

Dworzaczek W., Genealogia, t. II (Tablice), Warszawa 1959.

Dworzaczek W., Hetman Jan Tarnowski. Z dziejów możnowładztwa małopolskiego, Warszawa 1985.

Dygdała J., Sienieński Dominik, [w:] Polski słownik biograficzny, t. XXXVII, Warszawa-Kraków 1996-1997, s. 172-173.

Estreicher K., Bibliografia staropolska, t. XXI, Kraków 1906.

Fastnacht A., Słownik historyczno-geograficzny ziemi sanockiej w średniowieczu, do druku przygotowali A. Fastnacht-Stupnicka, A. Gassiorowski, cz. 2, Brzozów-Wzdów-Rzeszów 1998.

Gieysztorowa I., Niszczycki Stanisław, [w:] Polski słownik biograficzny, t. XXIII, Wrocław 1978, s. 139.

Gmiterek H., Sienieński Zbigniew, [w:] Polski słownik biograficzny, t. XXXVII, Warszawa-Kraków 1996-1997, s. 193-195.

Kaniewska I., Sienieński Jan, [w:] Polski słownik biograficzny, t. XXXVII, Warszawa-Kraków 1996-1997, s. 188-189. 
Kiryk F., Oleśnicki Dobiesław (właściwie Dobek z Oleśnicy i Sienna), [w:] Polski słownik biograficzny, t. XXIII, Wrocław 1978, s. 762-763

Kiryk F., Sienieński Andrzej z Sienna i Rymanowa, [w:] Polski słownik biograficzny, t. XXXVII, Warszawa-Kraków 1996-197, s. 172.

Kiryk F., Sienieński Wiktoryn z Sienna i Gołogór, [w:] Polski słownik biograficzny, t. XXXVII, Warszawa-Kraków 1996-1997, s. 192.

Kiryk F., Sienieński Zbigniew z Sienna i Rymanowa, [w:] Polski słownik biograficzny, t. XXXVII, Warszawa-Kraków 1996-1997, s. 192-193.

Kowalska H., Myszkowski Andrzej, [w:] Polski słownik biograficzny, t. XXII, Wroclaw 1977, s. 368-369.

Kurtyka J., Latyfundium tęczyńskie. Dobra i właściciele (XIV-XVII wiek), Kraków 1999.

Majewski W., Leniek Maciej z Rokitnicy, [w:] Polski słownik biograficzny, t. XVII, Wrocław-Warszawa-Kraków 1972, s. 52-53.

Pielas J., Oleśniccy herbu Dębno w XVI-XVII wieku. Studium z dziejów zamożnej szlachty doby nowożytnej, Kielce 2007.

Posłowie ziemscy koronni 1493-1600, oprac. W. Uruszczak, I. Kaniewska, M. Ferenc, J. Byliński, red. I. Kaniewska, Warszawa 2013.

Przyboś A., Kochanowski Jerzy z Konar, [w:] Polski słownik biograficzny, t. XIII, Wrocław-Warszawa-Kraków 1967-1968, s. 193.

Przyboś A., Lanckoroński Stanisław, [w:] Polski słownik biograficzny, t. XVI, Wrocław-Warszawa-Kraków 1971, s. 453-455.

Sokołowski W., Politycy schyłku złotego wieku. Małopolscy przywódcy szlachty i parlamentarzyści $w$ latach 1574-1605, Warszawa 1997.

Sperka J., Szafraniec Piotr młodszy z Pieskowej Skały, [w:] Polski słownik biograficzny, t. XLVI, Warszawa-Kraków 2009-2010, s. 464-468.

Strzelecki A., Sejm z r. 1605, Kraków 1921.

Szczygieł R., Nie zrealizowana lokacja Chocimowa w województwie lubelskim. O wpływach sporów granicznych na powstanie miast, „Roczniki Humanistyczne" 1987, t. XXXV, z. 2, s. 285-288.

Tarnawski A., Działalność gospodarcza Jana Zamoyskiego kanclerza $i$ hetmana w. kor. (1572-1605), Lwów 1935.

Urbaniak V., Zamoyszczycy bez Zamoyskiego. Studium dekompozycji ugrupowania politycznego, Warszawa 1995.

Urzędnicy województwa bełskiego i ziemi chełmskiej XIV-XVIII wieku. Spisy, oprac. H. Gmiterek i R. Szczygieł, red. A. Gąsiorowski, Kórnik 1992.

Urzędnicy województwa lubelskiego XVI-XVIII wieku. Spisy, oprac. W. Kłaczewski i W. Urban, red. A. Gassiorowski, Kórnik 1991.

Urzędnicy województwa sandomierskiego XVI-XVIII wieku. Spisy, oprac. K. Chłapowski i A. Falniowska-Gradowska, red. A. Gąsiorowski, Kórnik 1993.

Żychliński T., Złota księga szlachty polskiej, t. III, Poznań 1881.

Żychliński T., Złota księga szlachty polskiej, t. VIII, Poznań 1886. 
NOTKA O AUTORZE:

Prof. dr hab. Zbigniew Anusik - kierownik Katedry Historii Nowożytnej w Instytucie Historii Uniwersytetu Łódzkiego, członek Komitetu Nauk Historycznych Polskiej Akademii Nauk.

Zainteresowania naukowe: historia Polski i powszechna XVI-XVIII w., historia Szwecji XVI-XVIII w., stosunki polsko-szwedzkie w XVII-XVIII w., historia dyplomacji europejskiej w XVIII w., dzieje Wielkiej Rewolucji Francuskiej 1789-1799, elity dawnej Rzeczypospolitej, struktura własności ziemskiej w Rzeczypospolitej XVII w., genealogia polskich rodzin szlacheckich w XVI-XVIII w.

ত zbigniew.anusik@uni.lodz.pl 